\title{
Index for Volume 96 of Plant Disease
}

AUTHOR AND SUBJECT INDEX. Page numbers of errata are in italic. $\mathrm{N}$ indicates disease note.

Abad, J. A., 168

Abad, Z. G., 1080

Abdalla, O. A., 1705N

Abdelkhalek, A. A., 594N

Abed Ashtiani, F., $1227 \mathrm{~N}$

Abou-Jawdah, Y., 1231N, 1703N, 1704N

Abraham, A. D., 1045

Abrahamian, P. E., 1704N

Abu-Zaitoun, S. Y., 149N

Acacia koa (koa), Fusarium spp. on, AFLP pathogenicity, and VCG analyses, $460 \mathrm{~N}, 1111$ Acalymma vittatum (striped cucumber beetle), Erwinia tracheiphila on muskmelon and, 62

Acer pseudoplatanus, Neofusicoccum parvum on, in Italy, $1699 \mathrm{~N}$

Aceria tosichella (wheat curl mites), Triticum mosaic virus and Wheat streak mosaic virus in wheat and, 859

Acibenzolar-S-methyl (ASM), for control of

Xanthomonas spp. on tomato, 221

Acidovorax spp.

A. avenae subsp. avenae

on creeping bentgrass, identification, characterization, and distribution, 1736 on millet, in Korea, $1222 \mathrm{~N}$

A. citrulli

inhibitory effects of Chinese sumac gallnut extract on, 1193

on watermelon, seed inoculum load and spread in greenhouse conditions, 705

A. valerianellae, on watermelon, in Korea, $759 \mathrm{~N}$

Actinidia deliciosa (kiwifruit), Pseudomonas

syringae pv. actinidiae on, in Turkey, $452 \mathrm{~N}$

Adachi, N., 1033

Adaskaveg, J. E., 87, 235, 752

Addy, H. S., 1204

Adee, E. A., 957

Adenium obesum (desert rose), Cucumber mosaic virus in, in Taiwan, $593 \mathrm{~N}$

Adipala, E., 659

Adkins, S., 839, 1384N

Adriko, J., 760N

Adzuki bean. See Vigna angularis var. angularis

Aesthetics, viruses enhancing beauty of ornamentals and, 600

Agaricus bisporus (white button mushroom), Cladobotryum mycophilum on, 1067N

Agnostakis, S. L., 1392

Agrobacterium spp.

A. tumefaciens

cationic surfactant for disinfection of grafting tools and, 409

on walnut, role of systemic populations in disease incidence on hybrid rootstock, 1415

A. vitis, on grape, in Serbia, $286 \mathrm{~N}$

Agrostis stolonifera (creeping bentgrass)

Acidovorax avenae subsp. avenae on, identification, characterization, and distribution, 1736

Sclerotinia homoeocarpa on, in North Dakota, 1071N

Waitea circinata var. circinata on, in China, $1821 \mathrm{~N}$

Agudelo, P., 24, 30, 681, 1438, 1757

Aguín Casal, O., 589N

Agustí-Brisach, C., 1381N

Ahmad, J., 296N

Ahmed, M. Al, 1569

Ahmed, Y., 764N

Ahn, T.-Y., 577

Ailanthus altissima (tree-of-heaven),
Corynespora cassiicola on, $586 \mathrm{~N}$

Aime, M. C., 590N

Akanda, A. M., 917N

Aké, S., 1445

Akhtar, S., 1704N

Akhter, M. S., 917N

Akiba, M., 249

Akino, S., 537

Akrofi, A. Y., 292N

Alabi, O. J., 1074N

Alam, M., 293N

Alaniz, S., 458N, 914N, 1381N

Albarracín Orio, A. G., 1819N

Alder, black. See Alnus glutinosa

Alfalfa. See Medicago sativa

Alfalfa mosaic virus (AMV)

in basil, in California, 295N

diagnostic potential of polyclonal antibodies against bacterially expressed recombinant coat protein of, 1352

in Hibiscus rosa-sinensis, $462 \mathrm{~N}$, cover photo: March

in pepper and white clover, in Oklahoma, $1705 \mathrm{~N}$

in snap bean, crop and non-crop plants as reservoir hosts for, 506

in soybean, in North Dakota, 1829N

in tedera, in Australia, 1384N

in Teucrium fruticans, in Italy, 294N

Alfaro-Fernández, A., 581N, 582N

Alfenas, A. C., $1576 \mathrm{~N}$

Ali, A., 243, 1705N

Ali, S., 131

Ali-Shtayeh, M. S., 149N

Allium spp.

A. ampeloprasum (Egyptian leek), Iris

yellow spot virus in, 594N

A. cepa (onion)

Burkholderia cepacia and B. gladioli pv. alliicola on, effects of postharvest curing parameters on, 1548

Colletotrichum coccodes on, in Michigan, 769N

Fusarium oxysporum f. sp. cepae on, phylogenetic and biologica characterization of South African isolates, 1250

Iris yellow spot virus in, in Pennsylvania, $1229 \mathrm{~N}$

Pantoea ananatis on, in Korea, 1576N

Pseudomonas sp. on, $285 \mathrm{~N}$, cover photo: February

Shallot virus $X$ in, in Sudan, $1075 \mathrm{~N}$

Tomato spotted wilt virus in, in Serbia, $918 \mathrm{~N}$

A. fistulosum, for control of Ralstonia

solanacearum, 687

A. sativum (garlic)

Ditylenchus spp. on: D. destructor, in

Canada, 297N; D. dipsaci, in

Minnesota, $1707 \mathrm{~N}$, cover photo:

November

Embellisia allii on, in California, 291N

Fusarium proliferatum on, in India, $290 \mathrm{~N}$

Iris yellow spot virus in, $594 \mathrm{~N}$

Tomato spotted wilt virus in, in Serbia, $918 \mathrm{~N}$

Almond. See Prunus dulcis

Al-Mughrabi, K. I., 1729

Alnus glutinosa (black alder), Phytophthora alni on, in Spain, $589 \mathrm{~N}$

Aloe vera, Alternaria alternata on, in Louisiana, $1379 \mathrm{~N}$
Alternaria spp.

A. alternat

on Aloe vera, in Louisiana, $1379 \mathrm{~N}$

on cherry, in China, $1580 \mathrm{~N}$

on pomegranate, in Israel, 1513

on switchgrass, in Tennessee, 763N

on tangerine, resazurin-based microtite

assay for QoI sensitivity evaluation, 1262

on eggplant, in Malaysia, $1226 \mathrm{~N}$

A. helianthiinficiens, on sunflower, in Croatia, $1698 \mathrm{~N}$

A. japonica, on Chinese cabbage, in China, $1378 \mathrm{~N}$

A. longipes, on Atractylodes macrocephala, in China, $588 \mathrm{~N}$

A. petroselini, on fennel, in Spain, 907N

on potato, early control using disease-

oriented threshold values, 124

A. solani, on potato, boscalid-resistant

isolates, $454 \mathrm{~N}$

A. tenuissima, on pigeonpea, $907 \mathrm{~N}$, cover photo: June

Alternariaster helianthi, on sunflower, in

Louisiana, $761 \mathrm{~N}$

Alvare, L. A., 768N

Álvarez-Ojeda, J., 288N

Amatulli, M. T., 460N, 585N

Ambrosia trifida (giant ragweed), Septoria epambrosiae on, $289 \mathrm{~N}$

Ameline, A., 82

2-Aminoimidazole (2AI), Xanthomonas euvesicatoria on pepper and, 1638

Amphobotrys ricini, on Acalypha australis, in China, 460N

AMV. See Alfalfa mosaic virus

Ananas comosus (pineapple)

Exserohilum rostratum on, in China, $458 \mathrm{~N}$

Pineapple bacilliform $\mathrm{CO}$ virus-HI1 in,

diversity, detection, distribution, and transmission, 1798

Anco, D. J., 1297

Andelkovic, S., 913N

Anderbrant, O., 453N

Anderson, K. K., 648

Anderson, M. D., 1537

Anderson, N. A., 1227N

Andrade-Piedra, J. L., 1008

Anethum graveolens (dill), Erysiphe heraclei on, $907 \mathrm{~N}$

Ángel, J. C., $143 \mathrm{~N}$

Ann, P.-J., 1065N, 1224N

Annual bluegrass. See Poa annua

Antoniou, P. P., 304

Anubias barteri, Meloidogyne arenaria on, in China, $773 \mathrm{~N}$

Aphelenchoides spp.

A. bicaudatus

from ornamental nurseries in Taiwan, relationship with agricultural crops, 1763 on Phalaenopsis spp., 1763

A. fragariae, on hosta, 1438, cover photo: October

Aphids, Potato virus $Y$ and, 82

Aphis fabae (black bean aphid), Potato virus $Y$ and, 82

Apioplagiostoma populi, on poplar, in

Minnesota, $1227 \mathrm{~N}$

Apium graveolens (celery) Apium virus $Y$ in, 612, cover photo: May

Colletotrichum acutatum on in Michigan, $1383 \mathrm{~N}$ in U.S., $1692 \mathrm{~N}$ 
Apium virus $Y$ (ApVY), in celery, 612, cover photo: May

ApMV. See Apple mosaic virus

Apple. See Malus $\times$ domestica

Apple mosaic virus (ApMV), in apple, in

Alaska, 463N, cover photo: March

Apricot. See Prunus armeniaca

Apricot pseudo-chlorotic leaf spot virus

(APCLSV), in plum, in Czech Republic, 461N

ApVY. See Apium virus $Y$

Arachis hypogaea (peanut)

Cercospora arachidicola on, irrigation

timing, fungicide efficacy and, 1785

Cylindrocladium parasiticum on, in China, $583 \mathrm{~N}, 586 \mathrm{~N}$

Neocosmospora spp. on

N. striata, $146 \mathrm{~N}$

N. vasinfecta, $455 \mathrm{~N}$

Sclerotium rolfsii on

bioassay for fungicide systemicity, 330

irrigation timing, fungicide efficacy and, 1785

in Vietnam, 389

Arai, M., 845

Aralia elata, Ascochyta marginata on, 147N

Ares Yebra, A., 589N

Argüello-Astorga, G. R., 771N

Arias, M. E., $765 \mathrm{~N}$

Aristastoma guttulosum, on soybean, in China, $1694 \mathrm{~N}$

Aritua, V., 659

Armengol, J., $1381 \mathrm{~N}, 1826 \mathrm{~N}$

Armillaria tabescens, on peach, aboveground root collar excavation for management of, 681

Arnica montana, 16SrIII-B phytoplasma subgroup associated with virescence of, $1691 \mathrm{~N}$

Arriel, D. A. A., $1576 \mathrm{~N}$

Arroyo, F. T., 590N

Arsenault-Labrecque, G., 37

Artichoke. See Cynara scolymus

Artola, K., 1231N, 1430

Arvidsson, A. K., 453N

Ascochyta spp.

A. marginata, on Aralia elata, $147 \mathrm{~N}$

A. rabiei, on chickpea

in Argentina, $1375 \mathrm{~N}$

in Nebraska and South Dakota, 1073N

Ash, English. See Fraxinus excelsior

Ash, G. J., 629

Ashwagandha. See Withania somnifera

Askora, A., 1204

ASM. See Acibenzolar-S-methyl

Asma, M., 904N

Asparagus officinalis (asparagus), Puccinia asparagi on, 997, cover photo: October

Aspergillus niger, on cherry, in Greece, $458 \mathrm{~N}$

Atractylodes japonica (Chinese atractylodes),

Sclerotinia nivalis on, $1823 \mathrm{~N}$

Atractylodes macrocephala

Alternaria longipes on, $588 \mathrm{~N}$

Meloidogyne arenaria on, $1583 \mathrm{~N}$

Aubertot, J.-N., 935

Audenaert, K., 889

Augusto, J., 330

Avila-Quezada, G., 287N

Avocado. See Persea americana

Azegami, K., 1033

Azouaoui-Idjer, G., 1073N

Azoxystrobin

for Alternaria spp. on potato, early contro using disease-oriented threshold values, 124

for Macrophomina phaseolina and Phomopsis spp. on soybean, 1148

Baameur, A., 1383N

Babadoost, M., 1222N

Babaeizad, V., 1228N
Babiker, E. M., 1670

Bacillus spp., for control of pre- and post-

harvest diseases of apple, 211

Backman, P. A., 146N, 211

Bactericera spp., 'Candidatus Liberibacter solanacearum' and

B. cockerelli, potato and, 943,948

B. trigonica, carrot and, $581 \mathrm{~N}$

Bacteriophage

for control of Burkholderia spp. on rice, 1033

for control of Ralstonia solanacearum on tomato, 1204

Badea, A., 1271

Badebo, A., 623

Bae, S., $150 \mathrm{~N}$

Baenziger, P. S., 859

Bai, Q., 142N, 584N

Bai, Q. R., 1579N

Baiswar, P., 911N

Baixauli, C., 907N

Baker, C. A., 1384N

Balatti, P., 1067N

Balci, Y., 1080, 1608

Balogh, B., 221

Al-Balushi, Z. M., 852

Banana. See Musa acuminata

Bandyopadhyay, R., 292N, 1582N

Baranwal, V. K., 1828N

Barbetti, M. J., 769N, 1228N, 1382N

Barclay, C., 144N

Barham, J. D., 1805

Bark cracking viroid (CVd-IV), in Citrus sinensis and $C$. reticulata, in South Africa $772 \mathrm{~N}$

Barley. See Hordeum vulgare

BaRMV. See Basella rugose mosaic virus

Barrera, V., 456N

Basallote-Ureba, M. J., 990

Basella rugose mosaic virus (BaRMV), in Mirabilis jalapa (four o'clock), in China, 294N

Basella spp.

B. alba (Malabar spinach), Rhizoctonia solani AG 1-IB on, in India, 911N

B. rubra (Indian spinach), Rhizoctonia solani on, in Florida, 288N

Basil. See Ocimum basilicum

Bassimba, D. D. M., 907N

Bassoriello, M. M. I., 1698N

Bastas, K. K., 452N, 1690N, 1818N

Bastianel, M., 770N

Batson, W. E. Jr., 1805

Baudino, M., 1830N

Baudoin, A. B., 111

Baum, M., 1569

Baus, O., 1054

Bay, silk. See Persea humilis

Bayberry, Chinese. See Myrica rubra

Bayberry, red. See Myrica rubra

Baysal-Gurel, F., 1699N

BBWV-2. See Broad bean wilt virus 2

BCTV. See Beet curly top virus

Bean. See also Specific species

Beet mild curly top virus in, in Mexico, $771 \mathrm{~N}$

Tomato yellow leaf curl virus in, in China, $1229 \mathrm{~N}$

Beet curly top virus (BCTV), in sugar beet, management with insecticides, 1159

Beet mild curly top virus (BMCTV)

in bean, in Mexico, $771 \mathrm{~N}$

in sugar beet, management with insecticides, 1159

Beet necrotic yellow vein virus (BNYVV), in spinach, 618

Beet severe curly top virus (BSCTV), in sugar beet, management with insecticides, 1159

Beggarweed, Florida. See Desmodium tortuosum

Behlau, F., 221

Bélanger, R. R., 37

Belasque, J. Jr., 193

Belcher, A., 454N

Belcher, A. R., 460N

Belisario, A., 1695N

Bellardi, M. G., 294N

Bellflower. See Campanula rapunculoides

Beltrania rhombica, on Tibouchina

semidecandra, in China, $1380 \mathrm{~N}$

Bemisia tabaci (whitefly)

Squash vein yellowing virus in watermelon and, 839

Tomato yellow leaf curl virus in bean and, $1229 \mathrm{~N}$

Bencic, D., 290N

Bendezú-Euribe, M. V., 768N

Benincasa hispida (wax gourd), Fusarium

solani on, $294 \mathrm{~N}$

Bennett, R. S., 1564

Bentgrass, creeping. See Agrostis stolonifera

Benzen, S., 618

Beran, D., 1073N

Berbegal, M., 1826N

Berenji, J., 149N

Bergamini, M. P., 770N

Berger, G., 279

Bergsma-Vlami, M., 759N

Bergstrom, G., 1712

Bergstrom, G. C., 957

Berkelmann-Loehnertz, B., 1054

Bermudagrass, Meloidogyne marylandi on, in Florida, $1583 \mathrm{~N}$

Berner, D. K., 1578N

Berretta, M. F., 764N

Bertetti, D., 291N, 457N, 460N, 585N, 909N,

$910 \mathrm{~N}, 1381 \mathrm{~N}, 1823 \mathrm{~N}, 1824 \mathrm{~N}$

Bérubé, M.-E., 338

Beta vulgaris (sugar beet)

Cercospora beticola on, terconazole for, efficacy of different rates against isolates with different sensitivities to DMI fungicides, 1749

Fusarium spp. on, comparative pathogenicity and virulence, 1291

Heterodera schachtii (sugar beet cyst nematode) on, in North Dakota, $772 \mathrm{~N}$

Rhizoctonia spp. on

in Iran, 398

R. solani: AG-A, in China, $1696 \mathrm{~N}$; remote sensing for assessing severity of, 497

Bezos, D., 770N

Bhardwaj, S. C., 1580N

Bhatt, P. N., 1821N

Bi, Y., 797, 1231N

Bidens mottle virus (BiMoV), in

chrysanthemum and lettuce in Taiwan, 464N

Bienapfl, J. C., 1148, 1700N

Bigirimana, J., $1230 \mathrm{~N}$

BiMoV. See Bidens mottle virus

Biofilm formation, Xanthomonas euvesicatoria on pepper, foliar-applied small molecule suppressing, 1638

Biological control agents

Allium fistulosum extract for control of

Ralstonia solanacearum, 687

Bacillus spp., for control of pre- and postharvest diseases of apple, 211

bacteriophage, for control of Burkholderia spp. on rice, 1033

Phoma macrostoma for control of Conyza sumatrensis, $148 \mathrm{~N}$

Pseudomonas sp. BG33R, for management of Mesocriconema xenoplax on peach, 1309

Bionectria sp., on cardon cactus, in Mexico, $292 \mathrm{~N}$ 
Bipolaris peregianensis, on Cynodon dactylon, in China, $917 \mathrm{~N}$

Birithia, R., 1384N

Bischoff, J. F., 1822N

Biscogniauxia mediterranea, on English ash, in Italy, 1694N

Bissonnette, S. M., 459N

Bithell, S. L., 443

Bitternut hickory. See Carya cordiformis

Bituminaria bituminosa (tedera)

Alfalfa mosaic virus (AlMV) in, in Australia, $1384 \mathrm{~N}$

Phoma herbarum on, in Australia, 769N

Bixa orellana, Citrus leprosis virus $C$ in,

Brevipalpus phoenicis and, 968

Bizioli, L., $1381 \mathrm{~N}$

Black alder. See Alnus glutinosa

Black pine. See Pinus thunbergii

Black sigatoka disease. See Mycosphaerella fijiensis

Black swallow-wort. See Vincetoxicum nigrum

Blackberry. See Rubus fruticosus

Black-eyed Susan. See Rudbeckia hirta var. pulcherrima

Bleach, C. M., 144N

Blomquist, C. L., 905N, 1691N, 1829N

Bloodroot. See Sanguinaria canadensis

Blueberry. See Vaccinium corymbosum

Blueberry red ringspot virus (BRRSV), in

blueberry, in Korea, 1074N

Bluegrass. See Poa spp.

Blume, E., $1826 \mathrm{~N}$

BMCTV. See Beet mild curly top virus

BMCTV. See Beet mild curly top virus

BNYVV. See Beet necrotic yellow vein virus

Bockus, W. W., 957, 1501

Boeremia exigua, on pea, in Australia, 148N

Bolton, M., $591 \mathrm{~N}$

Bolton, M. D., 772N, 1749

Bon, M.-C., $585 \mathrm{~N}$

Bondalapati, K. D., 673

Boquel, S., 82

Bordovsky, J. P., 985

Borhani, B., 1228N

Borth, W. B., 917N, 1798

Boscalid

for Alternaria solani on potato, resistant isolates, $454 \mathrm{~N}$

for Botrytis cinerea on strawberry, resistance in South Carolina, 1198

Didymella bryoniae isolates and resistance to, 228

Boshoff, W. H. P., 590N

Bostock, R. M., 204, 752

Botella, L., 770N

Botryosphaeria spp.

B. dothidea

on apple, in China, 486

on blueberry, in China, 1697N

on Helwingia chinensis, 1821N

on hickory, 152

on pear, in Italy, $910 \mathrm{~N}$

B. iberica, on Monterey cypress, in Algeria, $1073 \mathrm{~N}$

on laurel-leaf fig, in California, $459 \mathrm{~N}$

B. obtusa, on olive, in Tunisia, $905 \mathrm{~N}$

Botryosphaeriaceae, on grape, evaluation of

fungicides for management of, 1303

Botrytis spp.

on blackberry and strawberry, identification and prevalence in Carolinas, 1634

B. caroliniana, on strawberry, in North Carolina, 914N

B. cinerea

frequency of transposable elements in populations from several hosts in Greece, 1286

on Heuchera plants, fenhexamidresistant, $147 \mathrm{~N}$ on Perilla frutescens, cover photo: June on shiso, in California, $908 \mathrm{~N}$ on strawberry: leaf wetness and temperature for timing of fungicide application, 529; resistance to pyraclostrobin and boscalid in South Carolina, 1198; in South Carolina, thiophanate-methyl resistance and, $1700 \mathrm{~N}$

Botschner, M., 666

Boty transposable element, in Botrytis cinerea on several hosts in Greece, 1286

Bouajila, A., 1569

Bourget, N., 338

Bourland, F. M., 1805

Boutigny, A.-L., 875

Bouznad, Z., 1073N

Boxwood. See Buxus spp.

Boyer, C., $581 \mathrm{~N}$

Bracalini, M., 1694N

Bradley, C. A., 767N, 957

Brassica spp.

B. campestris L. subsp. chinensis (Chinese cabbage), Alternaria japonica on, in China, $1378 \mathrm{~N}$

B. carinata (Ethiopian rapeseed), Sclerotinia sclerotiorum on, in Florida, 1581N

B. napus (canola) Ceratobasidium sp. on, in Washington state, $591 \mathrm{~N}$

clubroot in: in Australia, 1075N; resistant genotypes, 833

Rhizoctonia solani AG-2-1 on, in Washington state, $584 \mathrm{~N}$

B. narinosa (tatsoi), Hyaloperonospora brassicae on, in Korea, $1703 \mathrm{~N}$

B. oleracea var. capitata (cabbage), Phytophthora dreschleri on, in Argentina, $1830 \mathrm{~N}$

Brazilian ginseng. See Pfaffia glomerata

Brenneman, T. B., 330, 1785

Brevicoryne brassicae (cabbage aphid), Potato virus $Y$ and, 82

Brevipalpus phoenicis, Citrus leprosis virus $C$ in sweet orange and, 968

Breytenbach, J. H. J., 772N

Briddon, R. W., 1704N

Brito, J. A., 1706N

Broad bean wilt virus 2 (BBWV-2), in purple coneflower, in China, $1232 \mathrm{~N}$

Brock, J., 1066N

Broggini, G. A. L., 1791

Brooks, W. S., 279

Broomrape. See Orobanche cumana

Brown, D. S., 144N

Brown-Guedira, G., 737

BRRSV. See Blueberry red ringspot virus

Brücher, E., 1819N

Bruton, B. D., 761N, 1705N

BSCTV. See Beet severe curly top virus

Bubici, G., 304

Buchman, J. L., 18

Bugiani, R., 104

Bulajic, A., 149N, 912N, 918N, 1698N, 1706N

Bull, C. T., 285N, 904N, 1820N

Bunium persicum (kala zeera, black cumin),

Fusarium solani on, in India, $1067 \mathrm{~N}$

Buonaurio, R., 285N

Burkholderia spp.

B. cepacia, on onion, effects of postharvest curing parameters on, 1548

B. gladioli pv. alliicola, on onion, effects of postharvest curing parameters on, 1548

B. glumae, on rice bacteriophage for control of, 1033 detection by real-time bio-PCR, 577

B. plantarii, on rice, bacteriophage for control of, 1033

Burlakoti, P., 1291
Burrows, M., 1185

Bursaphelenchus xylophilus, on Pinus

thunbergii, 249

Bush, E. A., $581 \mathrm{~N}$

Butler, R. C., 443

Buxus spp. (boxwood)

Cylindrocladium buxicola on, in France, $1069 \mathrm{~N}$

Pratylenchus vulnus on, in Ohio, $1385 \mathrm{~N}$

Byamukama, E., 859

Byrne, J. M., 1383N

Cabanas, D., 917N

Cabbage. See Brassica campestris; Brassica oleracea

Cacao swollen shoot virus (CSSV), in cocoa, in Côte d'Ivoire, 1445

Cactodera cacti (cactus cyst nematode), on cactus, in China, $1385 \mathrm{~N}$

Cactus. See Cereus jamacaru

Cactus cyst nematode. See Cactodera cacti

Cadavid, M., 143N

Cadophora gregata f. sp. adzukicola, on adzuki bean, 562

Caesar, A. J., 145N, 1830N

Caesar-TonThat, T., 1830N

Caesar-Ton-That, T.-C., 145N

Caffi, T., 104

Cai, L., 143N, 1227N

Cai, M., $1821 \mathrm{~N}$

Cai, R., $581 \mathrm{~N}$

Cai, Z. D., $1229 \mathrm{~N}$

Cajanus cajan (pigeonpea), Alternaria tenuissima on, $907 \mathrm{~N}$, cover photo: June

Çakir, E., 1224N

Calendula officinalis (marigold), Pseudomonas viridiflava on, in Italy, $285 \mathrm{~N}$

Calic, A., 286N

Callery pear. See Pyrus calleryana

Calosphaeria pulchella, on cherry, in California and S. Australia, 648

Camacho, M., 590N

Camacho-Beltrán, E., 1229N

Câmara, M. P. S., 144N

Camargo, L. E. A., 151N, 589N

Camelina sativa, Hyaloperonospora camelinae on

detection, seed transmission, and chemical control, 1670

in Florida, 1692N

Camellia yellow mottle virus, in camellia, 600, cover photo: May

Campanula rapunculoides (creeping

bellflower), Golovinomyces orontii on, 291N, cover photo: February

Campbell-Nelson, K., 552

'Candidatus Liberibacter' spp.

'Ca. L. asiaticus', on Murraya paniculata,

Diaphorina citri and, 827

' $C a$. L. solanacearum'

on carrot: in Canary Islands, $581 \mathrm{~N}$; in

Norway, $454 \mathrm{~N}$; in Spain, $582 \mathrm{~N}$; in

Sweden, $453 \mathrm{~N}$

on potato: edge effect in disease intensity, 943; effects of temperature on symptom development, 18; in

Idaho, 453N; in Oregon and

Washington, $452 \mathrm{~N}$; in Texas panhandle, 948

'Candidatus Phytoplasma asteris', on woody

hosts, in Colombia, 1372N

Candresse, T., 461N

Canola. See Brassica napus

Cape gooseberry. See Physalis peruviana

Caprile, J., 648

Capsicum spp. (pepper)

C. annuum

Alfalfa mosaic virus in, in Oklahoma, $1705 \mathrm{~N}$ 
Cladosporium oxysporum on, $1072 \mathrm{~N}$, cover photo: July

Fusarium solani f. sp. piperis on, sexual reproduction of, $1581 \mathrm{~N}$

Stemphylium solani on, in Malaysia, $1227 \mathrm{~N}$

Xanthomonas spp. on: X. campestris pv. vesicatoria, in Saudi Arabia, $1690 \mathrm{~N} ; X$. euvesicatoria, foliar-applied small molecule that suppresses biofilm formation and enhances control of copper-resistant, 1638

C. chinense (chili pepper), Chili ringspot virus in, $462 \mathrm{~N}$

C. frutescens (chili pepper), Tomato ringspot virus in, in Iran, $1828 \mathrm{~N}$

Carbon dioxide, exposure to at curing temperature for control of Penicillium spp. on citrus, 423

Cardinale, J., 460N

Cardon cactus. See Pachycereus pringlei

Carmona, M., 456N, 1067N

Carmona, M. A., $1375 \mathrm{~N}$

Carnation. See Dianthus caryophyllus

Carrasco, J., 1067N

Carrot. See Daucus carota

Carrot psyllid. See Trioza apicalis

Carthamus tinctorius (safflower), Verticillium

dahliae on, in California, 1383N

Carya spp.

C. cathayensis (Chinese hickory)

Botryosphaeria dothidea on, 152

Colletotrichum gloeosporioides on, in China, $1825 \mathrm{~N}$

C. cordiformis (bitternut hickory), Fusarium solani, $455 \mathrm{~N}$

C. illinoinensis (pecan)

Fusicladium effusum on, two prediction models for, 117,1358

Pestalotiopsis clavispora on, in Brazil, $1826 \mathrm{~N}$

Xylella fastidiosa on, 1123

Castagnaro, A., $765 \mathrm{~N}$

Castañares, E., 763N

Castanea spp. (chestnut)

antimicrobial compounds from, 354

breeding for disease and insect resistance in U.S., 1392

Castrillo, L. A., 456N

Cating, R. A., 480, $1375 \mathrm{~N}$

Cationic surfactants, for Agrobacterium

tumefaciens contamination of grafting tools, 409

Cattleya orchid, Pseudocercospora odontoglossi on, 480

Cavalcante, G. P., 1576N

Cavicchi, L., 294N

Cavin, C. A., $1578 \mathrm{~N}$

Cazorla, F. M., 286N

CCYV. See Cucurbit chlorotic yellows virus

Cebrián, M. C., $581 \mathrm{~N}, 582 \mathrm{~N}$

Celery. See Apium graveolens

Celetti, M., 297N

Celtis australis (hackberry), Sirosporium celtidis on, in Spain, 1826N

Cephalosporium gramineum, on wheat, PCRbased detection, 437

Cerasus pseudocerasus (cherry), Alternaria alternata on, in China, $1580 \mathrm{~N}$

Ceratobasidium sp., on canola, in Washington state, $591 \mathrm{~N}$

Ceratocystis paradoxa on coconut, in China, $290 \mathrm{~N}$ on oil palm, 537

Cercospora spp.

C. arachidicola, on peanut, irrigation timing, fungicide efficacy and, 1785

C. beticola, on sugar beet, terconazole for, efficacy of different rates against isolates with different sensitivities to DMI fungicides, 1749

C. guatemalensis, on basil, in Korea, 1580N

C. sojina, on soybean

QoI fungicide-resistant, 767N

races 11 and $12,1067 \mathrm{~N}$

Cercosporella pfaffiae, on Brazilian ginseng, in Brazil, 1702N

Cereal cyst nematode. See Heterodera latipons

Cereus jamacaru (cactus), Cactodera cacti on, in China, $1385 \mathrm{~N}$

Cermák, V., $1386 \mathrm{~N}$

CEVd. See Citrus exocortis viroid

CGMMV. See Cucumber green mottle mosaic virus

Chai, W., 1634

Chaimovitsh, D., 370

Chambers, A. Y., 1805

Chamerion angustifolium (fireweed),

Phytophthora ramorum on, 1026

Chandra, S., 911N

Chang, C.-J., 582N

Chang, J.-M., 762N

Chang, Y. S., 593N

Chang, Y. W., 666

Chao, C. H., $910 \mathrm{~N}$

Chatfield, J., 1699N

Chatot, C., 935

Chattaoui, M., 905N

Chauvin, J.-É., 935

Chavan, N. S., 1074N

Chaves, A. M., 1736

Chayote. See Sechium edule

Chen, C. Q., 297N

Chen, C. T., 1193

Chen, C.-L., 582N

Chen, F., 1198

Chen, F. P., 416

Chen, F. Y., 588N

Chen, H., 1693N

Chen, H. R., 294N

Chen, H.-G., 1172

Chen, J., 1037, 1488

Chen, J. F., 1578N

Chen, J.-G., 1824N

Chen, L., 1495

Chen, L. J., 1385N, 1694N

Chen, P., 1763

Chen, R., 1519

Chen, S., 1693N

Chen, S. Y., 294N

Chen, T.-T., 544

Chen, W., 457N, 583N, 1615

Chen, W. Q., 1601

Chen, X., 586N

Chen, X. M., 67

Chen, X. R., 764N

Chen, X.-R., 1698N

Chen, Y., 1495

Chen, Y. K., 464N, 593N

Chen, Y.-K., $918 \mathrm{~N}$

Chen, Z. N., 760N, 1819N

Cheng, M., 1372N

Cheng, Y.-H., 918N

Chenopodium quinoa (quinoa), Peronospora variabilis on, $146 \mathrm{~N}$

Cheon, W., 766N

Chern, L. L., 1193

Cherry. See Cerasus pseudocerasus; Prunus cerasus

Cherry laurel. See Prunus laurocerasus

Cherry leaf roll virus (CLRV), in Hydrangea macrophylla, $463 \mathrm{~N}$

Chestnut. See Castanea spp.

Chew-Madinaveitia, Y. I., 1068N

Chiang, C.-H., $918 \mathrm{~N}$

Chickpea. See Cicer arietinum

Chicory. See Cichorium intybus

Childers, A. C., 943
Chili pepper. See Capsicum chinense; Capsicum frutescens

Chili ringspot virus (ChiRSV), in chili pepper, $462 \mathrm{~N}$

China rose. See Hibiscus rosa-sinensis

Chinese atractylodes. See Atractylodes japonica

Chinese bayberry. See Myrica rubra

Chinese cabbage. See Brassica campestris L. subsp. chinensis

Chinese fringe flower. See Loropetalum chinense

Chinese hickory. See Carya cathayensis

Chinese jujube. See Ziziphus jujuba

Chinese medicinal herbs, inhibitory effects on plant-pathogenic bacteria, 1193

Chinese sumac. See Rhus chinensis

Chinese tulip tree. See Liriodendron chinensis

Chirkov, S., 1135

ChiRSV. See Chili ringspot virus

Chitin, Leveillula taurica on tomato and, 1506

Chitosan, Leveillula taurica on tomato and, 1506

Chittem, K., 666

Chiu, Y.-H., 1065N

Chlorogenic acid, resistance of potatoes to soft rot and, 186

Cho, I. S., $1074 \mathrm{~N}$

Cho, J. D., 1074N

Cho, K. M., 1374N

Cho, M. S., 253, 577

Cho, S. E., 592N, 906N, 907N, 911N, 1072N, $1376 \mathrm{~N}, 1695 \mathrm{~N}, 1701 \mathrm{~N}$

Choanephora cucurbitarum, on ashwagandha, in India, 293N

Choi, G. S., 1074N

Choi, H. J., 253, 577

Choi, I. R., 1230N

Choi, J. K., 906N, 1222N

Choi, K. H., 1820N

Choi, O., 292N, 1576N

Choi, Y. J., 587N, 1703N, 1820N

Choueiri, E., 924

Chromogenic assay in plant pathogen DNA macroarray detection system, 1365

Chrysanthemum coronarium (garland chrysanthemum), Bidens mottle virus in, $464 \mathrm{~N}$

Chuang, M. F., 906N

Chung, B. N., 1074N, 1820N

Cicer arietinum (chickpea), Ascochyta rabiei on in Argentina, $1375 \mathrm{~N}$ in Nebraska and South Dakota, 1073N

Cichorium intybus (chicory, radicchio) Phytopthora cryptogea on, 591N Xanthomonas hortorum on, $1820 \mathrm{~N}$

Cilas, C., 1445

CiLV-C. See Citrus leprosis virus $C$

Cinnamomum spp.

C. kanehirae, Hinomyces moricola on, in Taiwan, $1226 \mathrm{~N}$

C. subavenium, Colletotrichum fioriniae on, in China, $143 \mathrm{~N}$

Cirulli, M., 304

Cisneros-López, E., 288N

Citrullus lanatus (watermelon)

Acidovorax spp. on A. citrulli, seed inoculum load and spread in greenhouse conditions, 705 A. valerianellae, in Korea, $759 \mathrm{~N}$

Colletotrichum orbiculare on, 431

Cucumber mosaic virus in, in Serbia, $1706 \mathrm{~N}$

Didymella bryoniae on, 431

baseline sensitivity and cross-resistance to succinate-dehydrogenase- inhibiting and demethylation-inhibiting fungicides, 979

fungicide sensitivity and control of, 1780

Monosporascus cannonballus on, in Mexico, $1068 \mathrm{~N}$

Serratia marcescens on, in Alabama, $761 \mathrm{~N}$ 
Squash vein yellowing virus in, whitefly transmission and, 839

Watermelon bud necrosis virus on, cover photo: April

Watermelon chlorotic stunt virus in, 149N, $1703 \mathrm{~N}$

Zucchini yellow mosaic virus in, in Serbia, $149 \mathrm{~N}$

Citrus exocortis viroid (CEVd), in Verbena sp., in Montenegro, $593 \mathrm{~N}$

Citrus leprosis virus $C$ (CiLVC)

in Commelina benghalensis, in Brazil, $770 \mathrm{~N}$

in sweet orange and alternate hosts,

Brevipalpus phoenicis and, 968

Citrus spp.

Cryptosporiopsis citricarpa on, in China, 804

Galactomyces citri-aurantii on,

propiconazole for management of, 235

C. reticulata (tangerine)

Alternaria alternata on, resazurin-based microtiter assay for QoI sensitivity evaluation, 1262

Bark cracking viroid in, in South Africa, $772 \mathrm{~N}$

short exposure to high $\mathrm{CO} 2$ and $\mathrm{O} 2$ at curing temperature to control postharvest diseases of, 423

C. sinensis (sweet orange)

Bark cracking viroid in, in South Africa, $772 \mathrm{~N}$

Citrus leprosis virus $C$ in, Brevipalpus

phoenicis and, 968

Guignardia citricarpa on, in North America, $1225 \mathrm{~N}$

Xylella fastidiosa on, responses to infection, 1245

Citrus tristeza virus (CTV), in Afghanistan, $296 \mathrm{~N}$

Citrus Viroid IV. See Bark cracking viroid

Cladobotryum mycophilum, on mushroom, $1067 \mathrm{~N}, 1374 \mathrm{~N}$

Cladosporium spp.

C. caryigenum, on pecan, two prediction models for, 117,1358

C. oxysporum, on pepper, $1072 \mathrm{~N}$, cover photo: July

C. variabile, on spinach, in California and Arizona, $1071 \mathrm{~N}$

Clark, C. A., 168, 1331

Clavibacter michiganensis subsp.

michiganensis, on tomato, genetic structure of populations in Michigan, 788

Clayton, L. A., $1705 \mathrm{~N}$

CLCuGeV. See Cotton leaf curl Gezira virus

Clonostachys rosea, on soybean, in U.S., 1700N

Cloutier, S., 1016

Clover, white. See Trifolium repens

CLRV. See Cherry leaf roll virus

Clubroot. See Plasmodiophora brassicae

CMV. See Cucumber mosaic virus

Coates, W. W., 648

Cocconia concentrica

on natal mahogany, in South Africa, 916N

on Trichilia emetica, cover photo: June

Cocoa. See Theobroma cacao

Cocos nucifera (coconut), Ceratocystis

paradoxa on, in China, $290 \mathrm{~N}$

Coerini, L. F., 770N

Coetzee, J. C., 916N

Coffee, dotted wild. See Psychotria punctata

Colcol, J. F., 111

Coleosporium pulsatillae, on windflower, in

China, $768 \mathrm{~N}$

Colletotrichum spp.

C. acutatum

on apple: in Czech Republic, $769 \mathrm{~N}$; in

Italy, 144N

on celery: in Michigan, 1383N; in U.S.,
$1692 \mathrm{~N}$

on Duchesnea indica, in Argentina,

$765 \mathrm{~N}$

on strawberry, cover photo: July; leaf wetness and temperature for timing of

fungicide application, 522; in

Montenegro, $1066 \mathrm{~N}$

on tamarillo, in United States, 587N

on tomato, in Czech Republic, 769N

on weeping willow, in California, 1822N

on apple, $458 \mathrm{~N}$, cover photo: March

C. chlorophyti, on soybean, $1699 \mathrm{~N}$

C. coccodes

on onion, in Michigan, 769N

on potato, impact of seed lot infection on, 1179

differential responses of strains isolated

from different hosts to multiple fungicides 1526

C. fioriniae, on Cinnamomum subavenium,

in China, $143 \mathrm{~N}$

C. gloeosporioides

on Chinese hickory, in China, $1825 \mathrm{~N}$

on crab apples, in Korea, $766 \mathrm{~N}$

on Cymbidium sinense, in China, $915 \mathrm{~N}$

differential responses of strains isolated

from different hosts to multiple

fungicides, 1526

on mile-a-minute, in Turkey, $1578 \mathrm{~N}$

on specked toadlily, 1070N

C. karstii, on Phalaenopsis spp., in United

States, $1227 \mathrm{~N}$

C. orbiculare, on watermelon, 431

C. sansevieriae, on Sansevieria trifasciata, in Florida, 293N

C. truncatum

differential responses of strains isolated

from different hosts to multiple fungicides, 1526

on lentil, 1118

Colocasia esculenta (taro), Phytophthora

colocasiae on, in Ghana, 292N

Colyer, P. D., 1805

Commelina benghalensis (spiderwort), Citrus

leprosis virus $C$ in, in Brazil, $770 \mathrm{~N}$

Comont, G., 924

Coneflower, purple. See Echinacea purpurea

Conidiosporomyces ayresii, on guinea grass, in

Japan, 143N

Conyza sumatrensis, Phoma macrostoma on, $148 \mathrm{~N}$

Cook, G., 772N

Copper, Xanthomonas euvesicatoria on pepper, foliar-applied small molecule suppressing, 1638

Coranson-Beaudu, R., 687

Coreopsis lanceolata (lanceleaf coreopsis),

Erysiphe arcuata on, in Korea, $1827 \mathrm{~N}$

Corkrey, R., 97

Corn. See Zea mays

Cornelius, E. W., 292N

Correl, J. C., 1822N

Correll, J. C., 769N, 1383N

Corylus avellana (hazelnut), Xanthomonas arboricola pv. corylina on, $1577 \mathrm{~N}$

Corynespora cassiicola

on cotton, in Georgia, 1066N

on gerbera, in China, $915 \mathrm{~N}$

on Korean raspberry, in Korea, 762N

on tree-of-heaven, $586 \mathrm{~N}$

Cosic, J., 591N, 1698N

Costa, S. S., $1581 \mathrm{~N}$

Cotoneaster horizontalis (rockspray), Erwinia amylovora on, in Turkey, $1690 \mathrm{~N}$

Cotton. See Gossypium hirsutum

Cotton leaf curl Gezira virus (CLCuGeV), in papaya, in Oman, 1704N

Coutinho, T. A., 186, 875

Coutts, B. A., 43, 1384N
Couty, A., 82

Cover crops, hairy vetch for control of diseases on watermelon, 431

Crabapple. See Malus prunifolia

Craig, J. P., 1556

Creeping bellflower. See Campanula

rapunculoides

Creeping bentgrass. See Agrostis stolonifera

Crespo, M., 286N

Cristulariella moricola, on soybean, in Korea, $906 \mathrm{~N}$

Cromey, M. G., 443

Cronartium flaccidum, black swallow-wort as alternate host of, $585 \mathrm{~N}$

Crop rotation

Rotylenchulus reniformis on cotton and, 24

Verticillium dahliae on cotton and, 985

Cross, C., 1154

Crosslin, J. M., 452N, 453N, 1074N

Croton spp., 'Candidatus Phytoplasma asteris' on, in Colombia, $1372 \mathrm{~N}$

Crous, P. W., 461N

Crow, W. T., $1583 \mathrm{~N}$

Cruz, C. D., 1501

Cryptosporiopsis citricarpa, on citrus, in China, 804

Csejk, Gy., 148N

CSSV. See Cacao swollen shoot virus

CTV. See Citrus tristeza virus

Cucumber. See Cucumis sativus

Cucumber green mottle mosaic virus

$(C G M M V)$, isolation from weeds and

cucurbits in Oklahoma, 243

Cucumber mosaic virus (CMV)

in desert rose, in Taiwan, 593N

isolation from weeds and cucurbits in

Oklahoma, 243

in Odontonema cuspidatum and Psychotria

punctata, in United States, 1384N

in snap bean, crop and non-crop plants as

reservoir hosts for, 506

in watermelon, in Serbia, 1706N

Cucumis spp.

C. melo (melon)

Monosporascus cannonballus on, in Mexico, $1068 \mathrm{~N}$

Watermelon chlorotic stunt virus in, in Lebanon, $1703 \mathrm{~N}$

C. melo (muskmelon), erwinia tracheiphila

on, 62

C. sativus (cucumber)

Cucurbit chlorotic yellows virus in, in Lebanon, $1704 \mathrm{~N}$

Phytophthora capsici on, evaluation for susceptibility to cucurbitaceous and solanaceous isolates, 1404

Pythium aphanidermatum on, phenotypic and genotypic changes in populations over 2006-2011, 852

Cucurbit chlorotic yellows virus (CCYV), in

cucumber, in Lebanon, $1704 \mathrm{~N}$

Cucurbita spp.

C. moschata (pumpkin)

Golovinomyces cichoracearum on, 906N

Xanthomonas cucurbitae on, in Illinois, $1222 \mathrm{~N}$

C. pepo (pumpkin), Xanthomonas

cucurbitae on, in Illinois, $1222 \mathrm{~N}$

Phytophthora capsici on, evaluation for susceptibility to cucurbitaceous and solanaceous isolates, 1404

Cucurbits. See also Specific cucurbits

Pseudoperonospora cubensis on, effects of temperature and leaf wetness on sporangia germination and infection, 345

Squash leaf curl virus in, in Lebanon, $1231 \mathrm{~N}$

Tobacco ringspot virus in, in Oklahoma, $1705 \mathrm{~N}$

Watermelon chlorotic stunt virus in, in 
Lebanon, $1703 \mathrm{~N}$

Cuellar, W. J., 168

Cui, R. Q., 1068N

Cumin, black. See Bunium persicum

Cuminum cyminum (cumin), Fusarium equiseti on, $1821 \mathrm{~N}$

Cummings, T. F., 1179

Cupressus macrocarpa (Monterey cypress),

Botryosphaeria iberica on, in Algeria, 1073N

Curt, M. D., 584N

Curtis, R. H. C., 865

Curtovirus spp., in sugar beet, management with insecticides, 1159

Curvularia spp.

C. fallax, on rice, in China, $1224 \mathrm{~N}$

C. lunata

on lotus, in China, $1068 \mathrm{~N}$

on Mexican nut, in Mexico, 288N

on switchgrass, in United States, 1372N

Cuscuta sp. (dodder), on ginseng, 297N

CVd-IV. See Bark cracking viroid

Cyazofamid, for Phytophthora capsici, 1337

Cylindrocarpon spp.

C. macrodidymum, on grape, in Turkey, $762 \mathrm{~N}$

C. pauciseptatum, on peach, in Italy, $764 \mathrm{~N}$

Cylindrocladiella spp.

C. parva, on grape in New Zealand, 144N in Spain, $1381 \mathrm{~N}$

C. peruviana, on grape, in Spain, $1381 \mathrm{~N}$

Cylindrocladium spp.

C. buxicola, on boxwood, in France, 1069N

C. parasiticum, on peanut, in China, $583 \mathrm{~N}$, $586 \mathrm{~N}$

C. pseudonaviculatum

on boxwood, in United States, 1070N on pachysandra, 1069N

Cymbidium mosaic virus (CymMV), in orchids, in Mexico, 464N

Cymbidium sinense, Colletotrichum gloeosporioides on, in China, $915 \mathrm{~N}$

CymMV. See Cymbidium mosaic virus

Cynanchum kashgaricum, Leveillula taurica on, 1373 N, cover photo: September

Cynara scolymus (artichoke), Pseudomonas

viridiflava on, $1223 \mathrm{~N}$

Cynodon dactylon, Bipolaris peregianensis on, in China, $917 \mathrm{~N}$

Cypress, Monterey. See Cupressus macrocarpa

Cyst nematode. See Heterodera elachista

Cytospora tritici, on Populus spp., in China, $1578 \mathrm{~N}$

Da Silva, W. L., 1379N

Daane, K. M., 1037

Dafallah, G., $1075 \mathrm{~N}$

Dafermos, N. G., 1506

Dai, F. M., 288N

Dai, W. A., 1378N

Daisy fleabane. See Erigeron strigosus

Dallagnol, L. J., 589N

Damasco, D., 458N

Dankers, H., 1581N, 1692N

Danti, R., 1073N

Dara, S., 612

Darrieutort, G., 924

Daucus carota (carrot)

'Candidatus Liberibacter solanacearum' on in Canary Islands, $581 \mathrm{~N}$

in Norway, 454N

in Spain, $582 \mathrm{~N}$

in Sweden, 453N

Pythium spp. on, fungicide sensitivity, 384

Daughtrey, M., 1373N

Daugovish, O., 612, 908N

Dave, S. R., 141N

Davidovitch-Rekanati, R., 370

Davis, D. D., 1381N
Davis, J. A., 168, 1331

Davis, R. M., 384, 1805

Daylily. See Hemerocallis spp.

Daza, A., 590N

De Araújo Filho, J. V., 151N

De Baets, B., 889

De Cara, M., 584N

De Castro, F. R., 589N

De Faria, R. S. C. A., 151N

De La Torre-Almaraz, R., 464N

De O. Abrantes, I. M., 865

De Oliveira, C. A. L., 968

De Oliveira, M. L., 968

De Rossi, R., 1819N

De Souza, R. M., 1820N

De Vallavieille-Pope, C., 131

De Vicente, A., 286N

De Wolf, E., 1712

Deahl, K. L., 1323

Deberdt, P., 687

Dee, M. M., 763N, 1372N

Degirmenci, K., 762N, 766N

Del Mar Jiménez-Gasco, M., 304

Del Río, M. A., 423

Del Rio Mendoza, L., 772N

Del Río Mendoza, L. E., 1315, 1749

Del Rio-Mendoza, L. E., 1291

Delaney, D. P., 1374N

Delaney, M. A., 1374N

Delayen, C., 82

Delgado, J. A., 1073N

Della Bartola, M., 771N

Della Rocca, G., 1073N

Delonix regia (flamboyant tree), Erysiphe quercicola on, $589 \mathrm{~N}$, cover photo: April

Delos, M., 131

Delphinium malabaricum, Phoma costarricensis on, in India, 1074N

Delvaux, B., 273

Demethylation-inhibitor fungicides (DMI) for Didymella bryoniae on watermelon, sensitivity and resistance, 979

for Erysiphe necator on grape, 111

Galactomyces spp. and, 87

for Monilinia fructicola, 416

Demirci, F., 762N, 766N, 1224N

Dendrobium candidum, Fusarium oxysporum on, in China, $1377 \mathrm{~N}$

Deng, M., 457N, 583N, 586N

Deng, Q., 583N, 586N

Deng, W.-L., $582 \mathrm{~N}$

Denny, T. P., 258

Deoxynivalenol (DON)

Fusarium graminearum and on barley, 279

integrating fungicide and cultivar resistance for management of, 957 timing of fungicide application and, 845

Gibberella zeae on barley and, weather-

based predictive models for, 673

Derie, M. L., 769N, 1071N

Desert rose. See Adenium obesum

Desjardin, D. E., 1227N

Desmodium tortuosum (Florida beggarweed), Phakopsora pachyrhizi on, in Alabama, $1374 \mathrm{~N}$

Dewdney, M. M., 1225N, 1262

Dey, K. K., 917N

Diabrotica undecimpunctata howardi (spotted cucumber beetles), Erwinia tracheiphila on muskmelon and, 62

Dianthus caryophyllus (carnation), Meloidogyne incognita on, poultry manure and soil solarization for management of, 990

Diaporthe australafricana, on blueberry, in Chile, $768 \mathrm{~N}$

Díaz, G. A., 768N, 1696N

Díaz Arias, M. M., 1693N

Díaz Ricci, J. C., 765N
Dickeya spp.

D. dieffenbachiae on phalaenopsis orchid, in China, $760 \mathrm{~N}$ on philodendron, in China, $452 \mathrm{~N}$

on potato, polyphenol oxidase, peroxidase, phenylalanine ammonia lyase, chlorogenic acid, and total soluble phenols and resistance, 186

D. zeae, on rice, in China, $1818 \mathrm{~N}$

Dickinson, M., 1372N

Dickson, D. W., 1706N

Didymella bryoniae

boscalid-resistant isolates, in South Carolina, 228

on chayote, in Taiwan, $1578 \mathrm{~N}$

on watermelon, 431, 979, 1780

Diez, J. J., 770N

Digiaro, M., 764N

Dill. See Anethum graveolens

Dill-Macky, R., 957, 1712

Dimethomorph, for Phytophthora capsici, 1337

Ding, D., 804

Ding, K.-J., 1495

Ding, L. L., 916N

Ding, S., $773 \mathrm{~N}$

Ding, Z., $151 \mathrm{~N}, 486$

Dinoor, A., 1060

Dion, Y., 338

Diplodia spp.

D. corticola, on live oak, 594

D. seriata, on olive, in Croatia, $290 \mathrm{~N}$

Diplotaxis tenuifolia (wild rocket),

Plectosphaerella cucumerina on, in Italy, $1825 \mathrm{~N}$

Disinfectants, cationic surfactants, for

Agrobacterium tumefaciens contamination of grafting tools, 409

Ditylenchus spp., on garlic

D. destructor, in Canada, $297 \mathrm{~N}$

D. dipsaci, in Minnesota, $1707 \mathrm{~N}$, cover photo: November

DMI. See Demethylation-inhibitor fungicides

DNA macroarrays, chromogenic, for plant

pathogen detection, 1365

Do, Y.S., $1820 \mathrm{~N}$

Dodge, S. C., 1675

Dolabra nepheliae, on rambutan and pulasan, in Honduras, $765 \mathrm{~N}$

Dolovac, N., 912N

Domier, L. L., 1829N

DON. See Deoxynivalenol

Donahoo, R., 1323

Dong, J., 1372N

Dong, J. G., 1064N

Dong, R., 584N, 1579N

Dong, X. L., 912N

Dong, Z. P., 1064N

D’Onghia, A. M., 764N

Donis-Gonzalez, I. R., 354

Douches, D., 712

Douda, O., $1386 \mathrm{~N}$

Douglas, S. M., 1069N, 1070N

Downer, A. J., 459N

Draeculacephala minerva, Xylella fastidiosa on almond and, 1488

Dragon fruit. See Hylocereus spp.

Dreo, T., $141 \mathrm{~N}$

Du, H. Z., 1696N

Du Toit, L. J., 769N, 1071N, 1548

Duan, Y. P., 288N, 827

Duan, Y. X., 1385N, 1694N

Ducasse, D. A., 1819N

Duchesnea indica, Colletotrichum acutatum on, in Argentina, $765 \mathrm{~N}$

Dudai, N., 370

Duduk, N., 456N

Dufault, N. S., $1581 \mathrm{~N}$

Dufualt, N. S., $1692 \mathrm{~N}$

Dullemans, A. M., 592N 
Dung, J. K. S., 379, 1179, 1819N

Dutra, C. B., $1826 \mathrm{~N}$

Dutra, D. C., $1697 \mathrm{~N}$

Dutta, B., 705, 1066N

Duyck, P.-F., 687

Dysmicoccus neobrevipes (gray pineapple mealybugs), Pineapple bacilliform CO virusHI1 in pineapple and, 1798

Dysphania ambrosioides (epazote), Erysiphe betae on, in Korea, $592 \mathrm{~N}$

Early warning systems. See Warning systems

Ebelhar, S. E., 957

Ebina, M., 143N

Echinacea purpurea (purple coneflower) 16SrII-A subgroup phytoplasma associated with, $582 \mathrm{~N}$

Broad bean wilt virus 2 in, in China, 1232N witches'-broom disease on, in Taiwan, $582 \mathrm{~N}$

Edema, R., 659

Egas, C., 865

Eggers, J. E., 452N, 1608

Eggplant. See Solanum melongena

Egyptian leek. See Allium ampeloprasum

Ehsani, R., 1683

Ehtemam, M. H., 1232N

Eickwort, J., 910N

El Amil, Roula, 924

Elaeis guineensis (oil palm), Ceratocystis paradoxa on, 537

Elfar, K., 768N, 1696N

Elizei, V. G., $1581 \mathrm{~N}$

Ellis, B. E., 1271

Ellis, M. A., 1297

Ellis, M. L., 1693N

Elmer, W. H., $1577 \mathrm{~N}$

El-Morsi, A. A., 594N

El-Shahaby, O. A., 594N

Elsinoё australis, on jojoba, in Australia, 629

Embellisia allii, on garlic, in California, 291N

English ash. See Fraxinus excelsior

Enjalbert, J., 131

Enterobacter cowanii, on Mabea fistulifera, $1576 \mathrm{~N}$

Enzenbacher, T. B., 769N, 1383N, 1404

Epazote. See Dysphania ambrosioides

Epilobium ciliatum (northern willowherb),

Phytophthora ramorum on, 1026

Epoxiconazole, for Fusarium spp. on wheat, 1495

Erigeron strigosus (daisy fleabane), Septoria erigerontis on, in Korea, $1827 \mathrm{~N}$

Erilmez, S., 1230N

Erjavec, J., 141N

Erkan, S., 1230N

Erper, I., 1578N

Erwinia spp.

E. amylovora

on blackberry, in Turkey, $1818 \mathrm{~N}$ on firethorn, in Turkey, $1818 \mathrm{~N}$ on mountain ash, in Turkey, $1818 \mathrm{~N}$ on plum, in Hungary, 759N

E. amylovora, on rockspray, in Turkey, $1690 \mathrm{~N}$

E. persicinus, on Medicago sativa, in China, $454 \mathrm{~N}$

E. tracheiphila, on muskmelon, 62

Erysiphe spp.

E. arcuata, on lanceleaf coreopsis, in Korea, $1827 \mathrm{~N}$

E. betae, on epazote, in Korea, $592 \mathrm{~N}$

E. heraclei, on dill, $907 \mathrm{~N}$

E. macleayae, on smallfruit plume poppy, in Poland, $1376 \mathrm{~N}$

E. necator, on grape, cover photo: May in Peru, 768N QoI fungicide-resistant in Michigan, 1621 sensitivity to demethylation inhibitor fungicides, 111

warning system for early-season control of, 104

E. quercicola, on flamboyant tree, $589 \mathrm{~N}$, cover photo: April

E. sedi, on Kalanchoe blossfeldiana, in

Korea, $1701 \mathrm{~N}$

Esca, on grape, 924, cover photo: July

Eskalen, A., 459N, 1070N

Esker, P. D., 957

Espinoza, J. G., 768N

Essential oils, for control of Phytophthora capsici, 797

Ethiopian rapeseed. See Brassica carinata

Eudes, F., 1271

Eujayl, I. A., 1159

Euphorbia spp.

Podosphaera sp. on, in Italy, 1824N

E. punicea (Jamaican poinsettia), Meloidogyne enterolobii on, in Florida, $1706 \mathrm{~N}$

E. tithymaloides (Jacob's ladder), Podosphaera euphorbiaehirtae on, in California, $1822 \mathrm{~N}$

Eustoma russellianum, Sclerotinia sclerotiorum on, in Taiwan, $910 \mathrm{~N}$

Eutypa lata, on grape, in Serbia, 913N

Euwallacea fornicatus (tea shot hole borer),

Fusarium sp. on avocado, tea shot hole borer and, $1070 \mathrm{~N}$

Everts, K. L., 431

Exadaktylou, E., 458N

Exserohilum rostratum, on pineapple, in China, $458 \mathrm{~N}$

Eyre, M. D., 1506

Eyres, N., 769N

Ezra, D., 1513

Faba bean. See Vicia faba

Faba bean necrotic stunt virus (FBNSV), on faba bean, in Ethiopia, 1045

Faba bean necrotic yellows virus (FBNYV), on faba bean, in Ethiopia, 1045

Fabi, A., 1577N

Fairchild, K., 454N

Fairy ring, preventative fungicide applications for control of in golf putting greens, 1001

Faivre, R., 935

Fajolu, O. L., 1372N

Fakhr, R., 285N

Fan, C.-J., $1072 \mathrm{~N}$

Fan, H. Y., 458N

Fan, J. R., 416

Fan, Y.-T., 918N

Fang, L., 1696N

Fang, X.-Z., 1495

Fargette, D., 1230N

Farzadfar, Sh., 771N

Fasseas, C., 1230N

Faure, C., 461N

FBNSV. See Faba bean necrotic stunt virus

FBNYV. See Faba bean necrotic yellows virus

Félix-Gastélum, R., 1229N

Feng, C., 769N, 1383N, 1822N

Feng, C. T., 1193

Feng, J. J., 452N, 760N, 1819N

Feng, L. N., 146N, 455N

Feng, Y., 766N

Fenhexamid, Botrytis cinerea on Huechera and, $147 \mathrm{~N}$

Fennel. See Foeniculum vulgare

Ferant, N., $1065 \mathrm{~N}$

Fermaud, Marc, 924

Fern. See Pteris cretica

Fernández-Ortuño, D., 911N, 914N, 1198, 1634, $1700 \mathrm{~N}$

Ferrándiz, J. C., 582N

Ferrari, B., 1067N

Ferri, M., 1067N
Ferrin, D. M., 590N, 761N

Ferro, J. A., 193

Ferro, M. I. T., 193

Fetch, T. Jr., 623

Fiallo-Olivé, E., 462N

Ficus microcarpa (Indian laurel-leaf fig),

Botryosphaeria spp. on, in California, $459 \mathrm{~N}$

Fig, laurel-leaf. See Ficus microcarpa

Figueira, A. R., 1451

Figueiredo, J. F. L., 221

Firespike. See Odontonema cuspidatum

Firethorn. See Pyracantha coccinea

Fireweed. See Chamerion angustifolium

Fish, W. W., 1705N

Fisher, T. W., 18

Flamboyant tree. See Delonix regia

Fleabane, daisy. See Erigeron strigosus

Fletcher, J., 761N

Flett, B. C., 881

Flipper transposable element, in Botrytis cinerea on several hosts in Greece, 1286

Florida beggarweed. See Desmodium tortuosum

Flor-Peregrín, E., 990

Floyd, C. M., 1700N

Foeniculum vulgare (fennel)

Alternaria petroselini on, in Spain, 907N

Fusarium avenaceum on, 145N, cover photo: January

Pseudomonas syringae pv. apii on, $285 \mathrm{~N}$, cover photo: February

Font, M. I., 581N, 582N

Foolad, M. R., 4

Forbes, G. A., 1008

Forecasting systems. See Models; Warning systems

Formento, A. N., 1375N

Formento, N., 1067N

Formosan cherry. See Prunus campanulata

Foroud, N. A., 1271

Förster, H., 87, 235

Foster-Hartnett, D., 1104

Fothergill, K., 1154

Four o'clock. See Mirabilis jalapa

Fournié, J. L., 1375N

Fourrier, C., $1069 \mathrm{~N}, 1375 \mathrm{~N}$

Fragariae $\times$ ananassa (strawberry)

Botrytis spp. on

$B$. caroliniana on, in North Carolina, $914 \mathrm{~N}$

$B$. cinerea on: resistance to pyraclostrobin and boscalid in South Carolina, 1198; in South Carolina, thiophanate-methyl resistance and, $1700 \mathrm{~N}$; on strawberry, leaf wetness and temperature for timing of fungicide application, 529

identification and prevalence in

Carolinas, 1634

Colletotrichum acutatum on, cover photo: July

leaf wetness and temperature for timing of fungicide application, 522 in Montenegro, $1066 \mathrm{~N}$

Fusarium oxysporum on, in South Carolina, $911 \mathrm{~N}$

Macrophomina phaseolina on, in Israel, 265 Pilidium concavum on, in China, $1377 \mathrm{~N}$

France, A., 591N

Franco-Lara, L., 1372N

Frare, G., 589N

Fraxinus spp.

F. excelsior (English ash), Biscogniauxia

mediterranea on, in Italy, 1694N

F. uhdei, 'Candidatus Phytoplasma asteris'

on, in Colombia, $1372 \mathrm{~N}$

Freeman, S., 265, 286N

Freesia hybrida, Stolbur phytoplasma in, $1820 \mathrm{~N}$

Freitas, D. M. S., 593N

Freitas-Astúa, J., 770N, 968 
French, R., 859

French-Monar, R. D., 1225N

Fringe flower, Chinese. See Loropetalum chinense

Fruehauf, C., 1054

Fry, W. E., 1323

Fu, B., $1065 \mathrm{~N}$

Fu, C. H., $1226 \mathrm{~N}, 1692 \mathrm{~N}, 1822 \mathrm{~N}$

Fu, J. F., $768 \mathrm{~N}, 1823 \mathrm{~N}, 1825 \mathrm{~N}$

Fu, Y., 288N, 1382N, 1824N

Fuchs, M. F., 1229N

Fuchsia spp., Pucciniastrum circaeae on, in Italy, $588 \mathrm{~N}$

Fuentes, S., 168

Fuji, S., 515

Fujie, M., 1204

Fulbright, D. W., 354, 780

Fulmer, A. M., 1066N

Fumonisin, Fusarium verticillioides on maize and, 881

Fungicides. See also Specific fungicides for Alternaria spp. on potato early control using disease-oriented threshold values, 124 resistant isolates, $454 \mathrm{~N}$

for Botryosphaeriaceae on grape, 1303

for Botrytis cinerea on strawberry resistance in South Carolina, 1198 weather and timing of application, 529

for Cercospora spp.

C. arachidicola, on peanut, timing of irrigation and, 1785

C. beticola, on sugar beet, 1749

C. sojina, on soybean, $767 \mathrm{~N}$

for Colletotrichum acutatum on strawberry, weather and timing of application, 522

for Didymella bryoniae on watermelon, 979, 1780

differential responses of Colletotrichum spp. isolated from different hosts to, 1526

for Erysiphe necator on grape, 111, 1621

for fairy ring in golf putting greens, 1001

for Fusarium spp.

F. graminearum: on barley, different soil tillages and, 338; on wheat, 338, 957 on seed potato tuber, 1767 on wheat, 1495; timing of application, mycotoxin contamination and, 845

Galactomyces spp. and, 87

for Geotrichum candidum on peach and nectarine, 752

for Macrophomina phaseolina on soybean, 1148

for Monilinia fructicola, 416

Penicillium spp. and, 87

for Phomopsis spp. on soybean, 1148

for Phytophthora spp.

P. capsici, 1337

P. infestans on potato, 1008

for Pythium spp. on carrot, 384

resazurin-based microtiter assay for sensitivity of Alternaria alternata isolates from tangerine, 1262

for Sclerotinia homoeocarpa on turfgrasses, 552

for Sclerotium rolfsii on peanut bioassay for fungicide systemicity, 330 timing of irrigation and, 1785

seed treatments for cotton, impact of, 1805

treatment of spring wheat fields with, 1537

for Venturia inaequalis on apple, reduced sensitivity to, in Virginia and Maryland, $1376 \mathrm{~N}$

Furtado, G. Q., 1576N

Furuya, H., 515

Fusarium spp.

F. armeniacum, on soybean, in U.S., 1693N

F. asiaticum, on wheat, pyraclostrobin and epoxiconazole for the control of, 1495
$F$. avenaceum, on fennel, $145 \mathrm{~N}$, cover photo: January

on avocado, tea shot hole borer and, $1070 \mathrm{~N}$

$F$. circinatum, in forest nursery, hydrogen

peroxide for sanitation, 875

F. equiseti, on cumin, $1821 \mathrm{~N}$

forecasting systems for, 889

F. graminearum

on barley: deoxynivalenol accumulation and resistance, 279; glyphosate and different soil tillages, 338; united effort to fight, 1712

on wheat: emergent Canadian chemotypes, 1271; geographic distribution of trichothecene chemotypes in China, 1172; glyphosate and different soil tillages, 338; integrating fungicide and cultivar resistance for management of, 957; molecular characterization of isolates from infected nursery in China, 1280; pyraclostrobin and epoxiconazole for the control of, 1495; united effort to fight, 1712

on koa, AFLP, pathogenicity, and VCG analyses, 1111

$F$. mangiferae, on mango

in China, $762 \mathrm{~N}$

in Spain, $286 \mathrm{~N}$

molecular phylogenetic analysis, trichothecene chemotype patterns, and variation in aggressiveness of isolates, 1016

F. oxysporum

on adzuki bean, 562

on bloodroot, $1577 \mathrm{~N}$

on Chinese jujube, in China, 586N

on Dendrobium candidum, in China, $1377 \mathrm{~N}$

on Iceland poppy, in Italy, 1823N

on onion, phylogenetic and biological

characterization of South African

isolates, 1250

on strawberry, in South Carolina, 911N

survival of chlamydospores under

solarization temperatures, 1564

on potato, seed tubers, fungicide sensitivity and, 1767

F. proliferatum

on garlic, in India, $290 \mathrm{~N}$

on jujube, in China, $913 \mathrm{~N}$

$F$. pseudograminearum

on barley, in Argentina, 763N

on wheat: assessing infection using quantitative PCR and visual discoloration scale, 1661; in China, $1065 \mathrm{~N}$

F. solani

on bitternut hickory, $455 \mathrm{~N}$

on kala zeera, in India, 1067N

on pepper, sexual reproduction of, $1581 \mathrm{~N}$

on tree peony, in China, $909 \mathrm{~N}$

on wax gourd, $294 \mathrm{~N}$

F. sporotrichioides, on lavender, in Croatia, $591 \mathrm{~N}$

on sugar beet, comparative pathogenicity

and virulence, 1291

$F$. tupiense, on mango, in Senegal, 1582N

$F$. verticillioides

on maize, resistance in inbred lines, fumonisin accumulation and, 881 on sorghum, in Spain, 584N

$F$. virguliforme, on soybean, symptomatic and asymptomatic host range, 1148

on wheat, fungicide application timing and mycotoxin contamination, 845

Fusicladium effusum, on pecan, two prediction models for, 117,1358
Fusicoccum aesculi, on tree peony, 1691N, cover photo: November

Gaar, V., 1386N

Gachango, E., 1767

Gadelseed, A. M. A., 1075N

Gadoury, D. M., 1653

Gaeumannomyces graminis var. tritici, on wheat, prediction using soil DNA concentrations determined with qPCR, 443

Gagnevin, L., 581N

Gai, Y., 457N, 586N

Gajda, B. E., 1384N

Galactomyces spp.

G. citri-aurantii

fungicide toxicity and resistance potential and, 87

propiconazole for management of, 235

G. geotrichum, fungicide toxicity and resistance potential and, 87

Gallegos Robles, M. A., 1068N

Galli, M., 1695N

Gallnut, inhibitory effects of extract from on plant-pathogenic bacteria, 1193

Galván, M., 456N

Gálvez, L., 584N

Galvino-Costa, S. B. F., 1451

Gao, B.-D., 1224N

Gao, D., $1821 \mathrm{~N}$

Gao, F., 586N

Gao, J., 142N, 289N, 297N, 584N, 1579N

Gao, T.-C., 1495

Gao, X., 1556

Gao, Z. L., $1827 \mathrm{~N}$

Gao, Z. M., $909 \mathrm{~N}$

Garber, R. H., 1805

Garcia, A. L., 1245

Garcia-Maruniak, A., 1690N

García-Morales, S., 287N

Garden lupin. See Lupinus polyphyllus

Gardenia jasminoides, 16SrI-B phytoplasma associated with symptoms on, $1576 \mathrm{~N}$, cover photo: October

Garibaldi, A., 291N, 457N, 460N, 585N, 588N, $909 \mathrm{~N}, 910 \mathrm{~N}, 1380 \mathrm{~N}, 1381 \mathrm{~N}, 1823 \mathrm{~N}, 1824 \mathrm{~N}$, $1825 \mathrm{~N}, 1830 \mathrm{~N}$

Garland chrysanthemum. See Chrysanthemum coronarium

Garlic. See Allium sativum

Gašic, K., 286N

Gaskins, V., $1823 \mathrm{~N}$

Gat, T., 1513

Gaura lindheimeri, Uromyces plumbarius on, in Louisiana, $590 \mathrm{~N}$

Gaytán-Mascorro, A., 1068N

Gazaway, W. S., 1805

GBNV. See Groundnut bud necrosis virus

Gbur, E., 1805

Gbur, E. E., 737

Ge, B.-B., 1704N

Gea, F. J., 1067N

Genetic variability, of Rotylenchulus reniformis, 30

Geng, W. L., 1377N

Geng, Y. H., 1691N

Gent, D. H., 583N, 726, 1343

Geotrichum candidum, on peach and nectarine, 204, 752

Gerard, P., 1438

Gerbera jamesonii, Corynespora cassiicola on, in China, $915 \mathrm{~N}$

Geric Stare, B., 773N

Gessler, C., 1791

GFkV. See Grapevine fleck virus

Al-Ghaithi, A. G., 852

Ghanbari, M. A. T., $1228 \mathrm{~N}$

Ghimire, S. R., $915 \mathrm{~N}$

Ghorbel, A., 1569

Ghosh, R., 907N 
Giant cardon. See Pachycereus pringlei

Giant ragweed. See Ambrosia trifida

Giant sequoia. See Sequoiadendron giganteum

Gibberella spp.

G. circinata, grass species as hosts of, $908 \mathrm{~N}$

G. persicaria, on dragon fruit, in China, $1826 \mathrm{~N}$

G. zeae, on barley, weather-based predictive models for, 673

Gibson, D. M., 456N

Gibson, R. W., 168

Gilardi, G., 588N, 1380N, 1825N, 1830N

Gilbert, J., 1016

Gil-Serna, J., 584N

Giménez Pecci, M. P., 1383N

Ginetti, B., 1694N, 1699N

Ginseng. See Panax ginseng; Pfaffia glomerata

Giolitti, F., 1383N

Giordanengo, P., 82

Giordano, P. R., 1736

Gislerød, H. R., 1653

Gitaitis, R., 285N

Gitaitis, R. D., 705, 1165

Giuliano Garisto Donzelli, B., 456N

Gleason, M. L., 62

Gliocephalotrichum bulbilium and G. simplex on rambutan in Puerto Rico, $1225 \mathrm{~N}$

Globodera pallida (pale potato cyst nematode), on potato

in Czech Republic, 1386N

in Slovenia, $773 \mathrm{~N}$

Glomerella cingulata

on apple, in China, $912 \mathrm{~N}$

on blueberry, in Argentina, 764N

Glover, K. D., 1743

GLRaV. See Grapevine leafroll-associated viruses

Glycine max (soybean)

Alfalfa mosaic virus in, in North Dakota, $1829 \mathrm{~N}$

Aristastoma guttulosum on, in China, 1694N

Cercospora sojina on

QoI fungicide-resistant, 767N races 11 and $12,1067 \mathrm{~N}$

Clonostachys rosea on, in U.S., 1700N

Colletotrichum chlorophyti on, 1699N

Cristulariella moricola on, in Korea, 906N

Fusarium spp. on

F. armeniacum, in U.S., $1693 \mathrm{~N}$

$F$. virguliforme, symptomatic and asymptomatic host range, 1148

Heterodera glycines on, qPCR for evaluation of cultivar resistance, 1556

Macrophomina phaseolina on cut-stem inoculation method for evaluating resistance, 1210 effect of lactofen, azoxystrobin, and genotypes, 1148

Nectria haematococca on, in China, $457 \mathrm{~N}$

Phakopsora pachyrhizi on

pathogenic variation of isolates in U.S. in 2006-2009, 75

silicon absorption and resistance to, 37

Phomopsis spp. on

in China, $1693 \mathrm{~N}$

effect of lactofen, azoxystrobin, and genotypes, 1148

Pseudomonas cichorii on, $142 \mathrm{~N}$

Soybean dwarf virus in, in North Dakota, $1829 \mathrm{~N}$

Glyphosate

for foliar diseases of alfalfa, 1104

for Fusarium graminearum on wheat and barley, different soil tillages and, 338

Gnayem, N., 265

Goates, B.J., 361

Goenaga, R., $1225 \mathrm{~N}$

Goggin, F., 1757

Golnaraghi, A. R., 771N
Golovinomyces spp.

G. biocellatus

on oregano, in Italy, 457N

on sage, in Slovenia, $1065 \mathrm{~N}$

G. cichoracearum

on pumpkin, $906 \mathrm{~N}$

on Sonchus asper, in China, $766 \mathrm{~N}$

G. orontii, on creeping bellflower, in Italy, $291 \mathrm{~N}$, cover photo: February

Gong, D., 462N

Gonsalves, D., 917N

Gonzales, A., $765 \mathrm{~N}$

Gonzalez, A., 1070N

González, A. J., 1067N

González, B. A., 1830N

González, P., 914N

González-Quintero, J., 288N

Gordon, T. C., 1471

Gordon, T. R., 145N, 908N

Gossypium hirsutum (cotton)

Corynespora cassiicola on, in Georgia, $1066 \mathrm{~N}$

impact of fungicide seed treatment and environment on seedling diseases of, 1805

Nigrospora oryzae on, in China, 1379N

Pythium spp. on, fungicide seed treatment and, 1805

Rhizoctonia solani on, fungicide seed treatment and, 1805

Rotylenchulus reniformis on, crop rotations and, 24

Verticillium dahliae on, effects of crop rotation, cultivar, irrigation and nitrogen rate on, 985

Goswami, R. S., 666, 1073N

Gottwald, T. R., 968

Gouma, S. E., 1223N

Goumas, D. E., 1223N, 1506

Gourlie, J. A., 1537

Gouws, R., 1223N

Grafting, for management of Ralstonia

solanacearum on tomato, 973

Gramaje, D., 1381N

Granke, L. L., 1379N, 1459, 1588

Grant, J., 648

Grape. See Vitis vinifera

Grapevine fleck virus (GFkV), in grape, in Idaho, $1705 \mathrm{~N}$

Grapevine leafroll-associated virus 1 (GLRaV$1)$, in grape, in India, $1828 \mathrm{~N}$

Grapevine leafroll-associated virus 2 (GLRaV-

2 ), in grape, in Missouri, $462 \mathrm{~N}$

Grapevine leafroll-associated virus 4 (GLRaV-

4 ), in grape, in Turkey, $1230 \mathrm{~N}$

Grassotti, A., 771N

Gratsia, M. E., 1230N

Gratton, C., 506

Gray pineapple mealybug. See Dysmicoccus neobrevipes

Graybosch, R. A., 859

Greenhagen, B. E., 1805

Greslebin, A., $1830 \mathrm{~N}$

Grevilea robusta, Citrus leprosis virus $C$ in, Brevipalpus phoenicis and, 968

Griffey, C. A., 279

Grisham, M. P., 150N, 1519

Groenewald, J. Z., 461N

Groth, D., 957

Groundnut. See Arachis hypogaea

Groundnut bud necrosis virus (GBNV), in tomato, in Bangladesh, $917 \mathrm{~N}$

Grove, G. G., 1343

Groves, R. L., 506, 1037

Grünwald, N. J., 1236

Grybauskas, A., 957

Gubler, W. D., 648, 1378N

Gudmestad, N. C., 693

Guermache, F., $585 \mathrm{~N}$

Guerra, F., 1819N
Guerra, G. D., 1819N

Gugino, B. K., 1692N

Guidarelli, M., 144N

Guignardia spp.

G. bidwellii, on grape, cumulative degreeday-based model to calculate the duration of the incubation period of, 1054

G. citricarpa, on sweet orange, in North America, $1225 \mathrm{~N}$

Guimarães, L. M. S., 1576N

Guinea grass. See Panicum maximum

Guirado, E., 286N

Gullino, M. L., 291N, 457N, 460N, 585N, $588 \mathrm{~N}, 909 \mathrm{~N}, 910 \mathrm{~N}, 1380 \mathrm{~N}, 1381 \mathrm{~N}, 1823 \mathrm{~N}$, $1824 \mathrm{~N}, 1825 \mathrm{~N}, 1830 \mathrm{~N}$

Guo, H., 1072N

Guo, J.-H., 1172

Guo, L., $1827 \mathrm{~N}$

Guo, L. W., 1826N

Guo, L. Y., 486

Guo, M., 909N

Guo, M. W., 1583N

Guo, W., 146N, 455N

Gupta, S. K., 1067N

Gupta, V., 1067N

Gusberti, M., 1791

Gutting, H. C., 1459

Gwinn, K. D., 763N, 1372N

Gymnosporangium sabinae, on Pyrus spp., in New York state, 1373N

Ha, Y., 258

Hackberry. See Celtis australis

Haesaert, G., 889

Hafez, E. E., 594N

Hahn, J. H., 253

Haidar, A., 1231N, 1703N

Hairy vetch. See Vicia villosa

Hajagos, L., 759N

Hajimorad, M. R., 1352

Hakiza, J. J., 659

Hale, A. L., $150 \mathrm{~N}$

Hall, D. G., 827

Halley, S. H., 673

Ham, J. H., 1123

Hamed, K., 1075N

Hamm, P. B., 452N

Hammond, J., 600

Han, H., 1706N

Han, K. S., 287N, 911N, 1070N, 1580N, $1701 \mathrm{~N}, 1827 \mathrm{~N}$

Han, K.-S., 759N

Han, S., 297N, 1579N

Han, Y.-K., 759N

Hannan, A., 906N

Hansen, M. A., 581N

Hanson, L. E., 904N, 1767

Hao, J. J., 354, 384, 712, 718, 797, 904N, 1767

Hao, Z. M., 1064N

Harakawa, R., $1826 \mathrm{~N}$

Harlan, B. R., 1379N

Harmon, P. F., 1262, 1692N

Hartley, D., 443

Hartman, G. L., 75, 1210, 1374N, 1699N

Harveson, R. M., 1073N

Hassett, B. T., 1222N

Haudenshield, J. S., 1374N, 1699N

Hausbeck, M. K., 769N, 780, 797, 1379N, $1383 \mathrm{~N}, 1404,1459,1588$

Hausladen, H., 124

Hawkweed, meadow. See Hieracium caespitosum

Hay, F. S., 746, 813

Hayat, Z., 906N

Hazelnut. See Corylus avellana

He, B., 1352

He, F., 458N

He, G., $1373 \mathrm{~N}$

He, M., 1578N 
He, T., $1379 \mathrm{~N}$

He, X. F., $151 \mathrm{~N}$

He, Y. Q., 904N, 1826N

He, Y.-B., 762N

He, Z.-F., $1702 \mathrm{~N}$

He, Z.-H., $1227 \mathrm{~N}$

Hébrard, E., $1230 \mathrm{~N}$

Hedera spp., Xanthomonas hortorum pv.

hederae on, $141 \mathrm{~N}$, cover photo: January

Hein, G. L., 859

Helianthus annuus (sunflower)

Alternaria helianthiinficiens on, in Croatia, $1698 \mathrm{~N}$

Alternariaster helianthi on, in Louisiana, $761 \mathrm{~N}$

Phoma macdonaldii on, in China, 1696N

Helwingia chinensis, Botryosphaeria dothidea on, $1821 \mathrm{~N}$

Hemerocallis spp. (daylily), Kabatiella

microsticta on, in China, $1579 \mathrm{~N}$

Henderson, G. W., 681

Henne, D. C., 943, 948

Herbicide, for foliar diseases of alfalfa, 1104

Herde, D. J., 1661

Heredia, M., 1245

Hermoso, J. M., 286N

Hermoso de Mendoza, A., 582N

Hernández, L., 458N

Hernández-Montiel, L. G., 292N

Herrera Pérez, T., 1068N

Herrera-Pérez, T., 1068N

Herrmann, A., 1060

Herselman, L., 590N

Hershman, D., 1712

Hershman, D. E., 957

Heterobasidion annosum, on Pinus pinaster, in Spain, $770 \mathrm{~N}$

Heterodera spp. (cyst nematodes)

$H$. avenae, fluidizing column for extraction of cysts from soil, 820

H. elachista, on rice, in China, $151 \mathrm{~N}$

$H$. filipjevi, on wheat, in Serbia, $1583 \mathrm{~N}$

H. glycines, on soybean, qPCR for evaluation of cultivar resistance, 1556

H. latipons, on wheat, in Morocco, 774N

H. schachtii, on sugar beet, in North Dakota, $772 \mathrm{~N}$

Heuchera plants, Botrytis cinerea on,

fenhexamid-resistant, $147 \mathrm{~N}$

Hevesi, M., $141 \mathrm{~N}$

Hibiscus rosa-sinensis (China rose)

Alfalfa mosaic virus in, $462 \mathrm{~N}$, cover photo: March

Citrus leprosis virus $C$ in, Brevipalpus phoenicis and, 968

Hickory. See Carya spp.

Hiddink, G., 904N

Hieracium caespitosum (meadow hawkweed),

Pilidium concavum on, in France, 1830N

Higbee, B. S., 1037

Hilber-Bodmer, M., 146N

Hilf, M. E., 968

Hill, C. B., 1210

Al-Hinai, F. M., 1704N

Hinomyces moricola, on Cinnamomum

kanehirae, in Taiwan, $1226 \mathrm{~N}$

Ho, H. H., 904N, 1826N

Ho, W. C., 1193

Hobbs, H. A., 1829N

Hodel, D. R., 459N

Hoepting, C. A., 1229N

Hog millet. See Panicum miliaceum

Holguín-Peña, R. J., 292N

Holkar, S. K., 917N

Hollaway, G. J., 569

Hollingsworth, C. R., 673

Holzinger, J., 296N

Hong, C. X., 915N

Hong, S. H., 289N, 1827N
Hop. See Humulus lupulus

Hop stunt viroid (HSVd), in hop, in Slovenia, $592 \mathrm{~N}$

Hordeum vulgare (barley)

Fusarium spp. on

$F$. graminearum: deoxynivalenol accumulation and resistance, 279; glyphosate and different soil tillages, 338; united effort to fight, 1712

F. pseudograminearum on, in Argentina, $763 \mathrm{~N}$

Gibberella zeae on, weather-based predictive models for, 673

Puccinia striiformis f. sp. hordei on, virulence, specificity, and distribution of races in U.S. in 2008-2009, 67

Pyrenophora teres on f. maculata, 569

f. teres, 1569

Host resistance

of adzuki bean, against Cadophora gregata f. sp. adzukicola and Fusarium oxysporum f. sp. adzukicola, 562

against Aphelenchoides fragariae, of hosta, 1438, cover photo: October

of asparagus, against Puccinia asparagi, 997

of barley

against Fusarium graminearum, 279

against Pyrenophora teres: f. maculata, 569; f. teres, 1569

against Bursaphelenchus xylophilus, of Pinus thunbergii, 249

against Cadophora gregata f. sp. adzukicola and Fusarium oxysporum f. sp. adzukicola of adzuki bean, 562

of canola, against Plasmodiophora

brassicae, 833

against Colletotrichum truncatum, of lentil, 1118

of corn, against Fusarium verticillioides, 881

against Fusarium spp.

F. graminearum: of barley, 279; of wheat, 957

F. oxysporum, of adzuki bean, 562

F. verticillioides, of maize, 881

against Heterodera glycines, of soybean, qPCR for evaluation of, 1556

of hosta, against Aphelenchoides fragariae, 1438, cover photo: October

of lentil, against Colletotrichum truncatum, 1118

against Macrophomina phaseolina, of soybean, cut-stem inoculation method for evaluating, 1210

against Magnaporthe oryzae pv triticum, of wheat, assessment of in U.S. cultivars, 1501

against Phakopsora pachyrhizi, of soybean, silicon and, 37

against Phytophthora infestans, of potato and tomato, 4

of Pinus thunbergii, against

Bursaphelenchus xylophilus, 249

against Plasmodiophora brassicae, of canola, 833

of potato

against Phytophthora infestans, 4 polyphenol oxidase, peroxidase, phenylalanine ammonia lyase, chlorogenic acid, and total soluble phenols and, 186

against Potato virus $X, 43$

against Potato virus $X$, of potato, 43

against Potyvirus spp., of sorghum, 1775

against Puccinia spp.

P. asparagi, of asparagus, 997

P. striiformis f. sp. tritici, of wheat, 131, 737,1482 against Pyrenophora teres, of barley

f. maculata, 569

f. teres, 1569

of sorghum

in mini-core germplasm collection, 1629

against Potyvirus spp., 1775

of soybean

against Heterodera glycines, qPCR for evaluation of, 1556

against Macrophomina phaseolina, cutstem inoculation method for evaluating, 1210

against Phakopsora pachyrhizi, silicon and, 37

of tomato

against Phytophthora infestans, 4

against Xanthomonas spp., 221

of wheat

against Fusarium graminearum, integrating with fungicide application, 957

against Magnaporthe oryzae pv triticum, assessment of in U.S. cultivars, 1501

against Puccinia striiformis $\mathrm{f}$. sp. tritici, 131, 737, 1482

against Xanthomonas campestris pv. translucens, evaluation of germplasm for, 1743

against Xanthomonas spp.

$X$. campestris pv. translucens, of wheat, evaluation of germplasm for, 1743 of tomato, 221

Hosta, Aphelenchoides fragariae on, 1438,

cover photo: October

Hou, L., 1482

Howard, R. J., 1729

Howlett, B. J., 569

Hoy, M. A., 480

Hsiang, T., 909N

HsVd. See Hop stunt viroid

$\mathrm{Hu}$, C.-H., 1323

$\mathrm{Hu}, \mathrm{F} . \mathrm{C} ., 458 \mathrm{~N}$

Hu, J. S., 917N, 1798

Hu, J.-X., $1072 \mathrm{~N}$

$\mathrm{Hu}, \mathrm{L} ., 148 \mathrm{~N}$

$\mathrm{Hu}, \mathrm{P} ., 1377 \mathrm{~N}$

$\mathrm{Hu}, \mathrm{X} ., 1615$

Hu, X. Q., 1232N

$\mathrm{Hu}, \mathrm{Y}-\mathrm{C}, 1172$

Hua, M., 458N

Huang, C., 544

Huang, C. X., 773N

Huang, C.-H., 221

Huang, F., 804

Huang, G.-X., 1072N

Huang, J., 1482

Huang, J. H., 915N, 1380N

Huang, J.-H., 1065N

Huang, L., 1645

Huang, R., 1303

Huang, T. C., 910N

Huang, W., 1224N

Huang, W. K., 151N

Huang, X.-Y., 1072N

Huang, Y. P., 1692N, 1822N

Huanglongbing. See 'Candidatus Liberibacter asiaticus'

Hubert, J., 1375N

Hudler, G., 1373N

Hughes, B., 297N

Hughes, M. A., $910 \mathrm{~N}$

Hughes, M. E., 1216

Huigens, R. W. III, 1638

Hulbert, S. H., 1670

Humann, J. L., 1548

Humulus lupulus (hop)

Hop stunt viroid in, in Slovenia, 592N

Pseudoperonospora humuli and

Podosphaera macularis on, spring pruning 
practices and, 1343

Pseudoperonospora spp. on, host specificity and, 55

Sclerotinia sclerotiorum on, $583 \mathrm{~N}$

Hussein, E. Y., 149N

Hutmacher, R. B., 1805

Hyaloperonospora spp.

H. brassicae, on tatsoi, in Korea, 1703N

H. camelinae, on Camelina sativa detection, seed transmission, and chemical control, 1670 in Florida, 1692N

on spider flower, $587 \mathrm{~N}$, cover photo: April

Hyde, K., 1227N

Hyde, K. D., 804

Hydrangea macrophylla

Cherry leaf roll virus in, $463 \mathrm{~N}$

Oidium hortensiae on, in Korea, 1072N

Hydrogen peroxide, for sanitation of Fusarium

circinatum in forest nursery, 875

Hylocereus spp. (pitahaya, dragon fruit)

H. costaricensis, Gilbertella persicaria on, in China, $1826 \mathrm{~N}$

H. polyrhizus, Neoscytalidium dimidiatum on, in Taiwan, $906 \mathrm{~N}$

H. undatus, Neoscytalidium dimidiatum on in China, $1702 \mathrm{~N}$ in Taiwan, $906 \mathrm{~N}$

Hypersensitive response (HR)

potato resistance to Potato virus $X$ and, 43 soybean resistance to Phakopsora pachyrhizi and, 37

Hyphodermella rosae, on plum, in Iran, 1228N

Hytönen, T., $1231 \mathrm{~N}$

Hyun, J.-W., 629

Ibrahim, Y., 1690N

Iceland poppy. See Papaver nudicaule

Icishahayo, D., 186

Ilyonectria macrodidyma, on olive, in California, $1378 \mathrm{~N}$

Impatiens necrotic spot virus (INSV), in potato, in Iran, $771 \mathrm{~N}$

Impatiens walleriana, Plasmopara obducens on, $148 \mathrm{~N}, 1699 \mathrm{~N}$

Inch, S. A., 1683

Indian laurel-leaf fig. See Ficus microcarpa

Indian spinach. See Basella rubra

Ingram, J. T., 1179

Inman, M. K., 1070N

Inoue, Y., 1033

Insecticides, for management of Curtovirus spp. in sugar beet, 1159

INSV. See Impatiens necrotic spot virus

Ioos, R., 1069N, 1375N

Ipomoea batatas (sweet potato)

15 years progress understanding and managing viral diseases of, 168

Phomopsis ipomoeae-batatas on, in Korea, $1701 \mathrm{~N}$

small-RNA deep-sequencing for detection of viruses in, 1430

Sweet potato feathery mottle virus in, effect of host plant, aphid species, and virus infection status on transmission of, 1331

Iresine herbstii, Sclerotium rolfsii on, in

Taiwan, 1692N

Iribarren, M. J., 1830N

Iris yellow spot virus (IYSV)

in garlic and Egyptian leek, 594N

in onion, in Pennsylvania, 1229N

in spiny sowthistle, in Georgia, 1165

Irrigation

Cercospora arachidicola and Sclerotium rolfsii on peanut, timing of, fungicide efficacy and, 1785

Verticillium dahliae on cotton and, 985

Isakeit, T., $1222 \mathrm{~N}$

Isakeit, T. S., 1805
Ishihara, M., 249

Ito, D., 1185

Ito, T., 515

Ivanov, P., 1135

Ivanovic, M., 286N

Ivanovic, M. M., 456N

Ivanovic, M. S., $456 \mathrm{~N}$

Ivanovic, Ž., $1583 \mathrm{~N}$

Ivic, D., $290 \mathrm{~N}$

Ivors, K., 1080, 1323

Ivors, K. L., 1070N

Ivy. See Hedera spp.

Iwadate, Y., 515

IYSV. See Iris yellow spot virus

Izquierdo, P. M., 1381N

Al-Jabri, A. H., 852

Jaciani, F. J., 193

Jackson, K. L., 294N, 1337

Jacob's ladder. See Euphorbia tithymaloides

Jadrane, I., $1227 \mathrm{~N}$

Jain, R. K, 1828N

Jain, R. K., 468, 917N

Jakse, J., 592N, 1065N

Jamaican poinsettia. See Euphorbia punicea

James, D., 1135

Jamous, R. M., 149N

Jan, F.-J., $582 \mathrm{~N}$

Janisiewicz, W. J., 1823N

Japanese black pine. See Pinus thunbergii

Jardini, T. M., 285N

Jaspers, M. V., 144N

Jatropha curcas (Mexican nut, physic nut) Curvularia lunata on, in Mexico, 288N

Lasiodiplodia theobromae on, in Malaysia, $767 \mathrm{~N}$

Neoscytalidium dimidiatum on, in Brazil, $1697 \mathrm{~N}$

Javornik, B., 592N, 1065N

Jawhari, M., 1231N, 1703N

Jeffers, D., $1582 \mathrm{~N}$

Jen, F.-Y., 1763

Jensen, S., 1373N

Jeon, Y. H., 766N

Jerusalem artichoke, Sclerotinia sclerotiorum on, cover photo: January

Jevremovic, D., 913N

Jeyaprakash, A., $1225 \mathrm{~N}$

Ji, C., $583 \mathrm{~N}$

Ji, P., 294N, 1337

Ji, Y. H., 1229N

Jiang, H., 797

Jiang, H. H., 904N

Jiang, H.-X., 1698N

Jiang, Y. L., 906N

Jiang, Z.-D., 1702N

Jiménez-Díaz, R. M., 304

Jin, Y., 623

Jing, J., 1482

John, D., 1067N

Johnson, D. A., 379, 997, 1179, 1819N

Jojoba. See Simmondsia chinensis

Jones, A. D., 354

Jones, E. E., 144N

Jones, J. B., 221, 285N

Jones, R. A. C., 43, 1384N, 1430

Jones, R. W., $587 \mathrm{~N}$

Jordan, K. S., $1698 \mathrm{~N}$

Josic, D., 1691N

Jossey, S., 459N

Jreijiri, F., 924

Juglans regia (walnut)

Agrobacterium tumefaciens on, role of systemic populations in disease incidence on hybrid rootstock, 1415

Phytophthora megasperma on, in Italy, $1695 \mathrm{~N}$

Jujube. See Ziziphus jujuba

June bellflower. See Campanula rapunculoides
Jung, G., 552

Jung, J., $150 \mathrm{~N}$

Jung, T., 1694N

Jurick, W. M. II, $1823 \mathrm{~N}$

Jurkovic, D., $591 \mathrm{~N}, 1698 \mathrm{~N}$

Juzwik, J., 455N

Kabatiella microsticta, on daylily, in China, $1579 \mathrm{~N}$

Kablan, L., 273

Kadir, J., 767N

Kadir, J. B., 1226N, 1227N

Kala zeera. See Bunium persicum

Kalanchoe blossfeldiana

Erysiphe sedi on, in Korea, 1701N

Stemphylium xanthosomatis on, in Korea, $292 \mathrm{~N}$

Kalimeris indica, Potato virus $Y$ in, in China, $1827 \mathrm{~N}$

Kalischuk, M. L., 1729

Kaliterna, J., 290N

Kalmia latifolia (mountain laurel),

Phytophthora cinnamomi on, 1381N

Kamble, S. S., 1074N

Kandel, Y. R., 1743

Kandouh, B., 917N

Kang, D.-W., 762N

Kang, M. J., 253, 577

Kang, Z., 1482, 1615, 1645

Kanuya, E., 1705N

Karakaya, A., 452N

Karaoglanidis, G. S., 1286

Karasev, A. V., 1451, 1705N

Karimmojeni, H., 1232N

Kashif, M., 1430

Kasina, M., 1582N

Kasselaki, A. M., 1506

Kaufman, H. W., 1805

Kaur, R., 590N

Kawasaki, T., 1204

Kawchuk, L. M., 1729

Kaya, A., 1230N

Ke, X., 1645

Kébé, B. I., 1445

Keeling, J. W., 985

Keinath, A. P., 228

Keith, L., 917N

Kelly, D., 909N

Kemerait, R. C., 1805

Kemerait, R. C. Jr., $1066 \mathrm{~N}$

Kenaley, S., 1373N

Kendra, D. F., 1271

Kentucky bluegrass. See Poa pratensis

The Key to the Common Phytophthora species, 897

Khaliq, A., 293N

Khan, A. J., 1704N

Khan, M. F. R., 1291, 1749

Khangura, R. K., 1075N

Khatabi, B., 1352

Khatibi, P. A., 279

Khattab, A., 243

Khurram, R., 906N

Kim, B. K., 253, 577

Kim, C., 253

Kim, H., 150N

Kim, J., 292N, 577, 762N, 1576N

Kim, J. Y., 907N, 1580N, 1701N, 1703N

Kim, J.-S., 258

Kim, M. H., 253, 577

Kim, M. K., 1374N

Kim, S., $759 \mathrm{~N}$

Kim, S. H., 253

Kim, T.-S., $1576 \mathrm{~N}$

Kim, Y. S., 766N

Kinyua, Z. M., 1582N

Kinzer, K., 666, 1071N

Kirk, W. W., 460N, 1621, 1767

Kirkpatrick, S. C., 145N 
Kirkpatrick, T., 1757

Kirkpatrick, T. L., 1805

Kitajima, E. W., 770N, 968

Kiwifruit. See Actinidia deliciosa

Klos, K. L. E., 437

Kluepfel, D. A., 409, 1309, 1415

Knight, N. L., 1661

Knorst, V., 146N

Knotweed, giant. See Reynoutria sachalinensis

Koa. See Acacia koa

Koelreuteria bipinnata var integrifoliola,

Lasiodiplodia theobromae on, in China,

$1579 \mathrm{~N}$

Koenraadt, H., 759N

Koike, S. T., 145N, 285N, 291N, 296N, 612,

$908 \mathrm{~N}, 1383 \mathrm{~N}, 1820 \mathrm{~N}, 1822 \mathrm{~N}$

Kokalis-Burelle, N., 296N

Kolander, T. M., 1148

Kolmer, J. A., 1216

Komorowska, B., 594N

Kondo, N., 537, 562

Kong, P., 915N

Korean raspberry. See Rubus crataegifolius

Kornievsky, M., 1227N

Kosman, E., 1060

Kouakou, K., 1445

Kouassi, N., 1445

Kouki, K., 143N

Kozik, E. U., 4

Kreuze, J. F., 168

Krishna Kumar, N. K., 468

Krishnareddy, M., 468

Kromann, P., 1008

Kropf, S. M., 583N

Krstic, B., 149N, 912N, 918N, 1698N, 1706N

Krugner, R., 1488

Kruijt, M., 389

Kumar, A., 141N, 293N

Kumar, R., $911 \mathrm{~N}$

Kumar, S., $1828 \mathrm{~N}$

Kurle, J. E., 1148

Kurokura, T., $1231 \mathrm{~N}$

Kuzmanovic, N., 286N

Kwak, Y.-S., 762N

Kwon, J.-H., 292N, 762N

Kwon, Y. D., 1070N

Kyriakopoulou, P. E., 1230N

Lacey, L. W., 1070N

Lactofen, for Macrophomina phaseolina and

Phomopsis spp. on soybean, 1148

Lactuca sativa (lettuce)

Bidens mottle virus in, 464N

Phoma tropica on, in Italy, 1380N

Laetisaria fuciformis, on seashore paspalum, in

China, 1374N

Lagauche, A., 273

Laguette, S., 497

Laguna, G., $1383 \mathrm{~N}$

Lai, S. Y., $906 \mathrm{~N}$

Lambert, K. N., 1556

Lambert, S. J., 813

Lamichhane, J. R., 1577N

Lamine Senghor, A., 1582N

LaMondia, J. A., 1069N, 1070N, 1378N

Lamour, K., 1588

Lamppa, R. S., 666

Lan, G.-B., $1702 \mathrm{~N}$

Lanceleaf coreopsis. See Coreopsis lanceolata

Landeras, E., $1381 \mathrm{~N}$

Landers, N. A., 780

Landschoot, S., 889

Langston, D., 285N

Langston, D. B. Jr., 979, 1780

Lannon, K. R., 693

Lanoiselet, V., 769N, 1228N, 1382N

Lanzoni, C., 296N

Lapaz, M. I., 1064N

Lartey, R. T., $145 \mathrm{~N}, 1830 \mathrm{~N}$
Lasiodiplodia theobromae

on avocado, in Italy, $460 \mathrm{~N}$

on Koelreuteria bipinnata var integrifoliola,

in China, 1579N

on physic nut, in Malaysia, $767 \mathrm{~N}$

Laski, P. J., 1372N

Latinovic, J., 1066N

Latinovic, N., $1066 \mathrm{~N}$

Latisnere, H., 292N

Latoni-Brailowsky, E. I., $1225 \mathrm{~N}$

Latorre, B. A., 768N, 1696N

Laurel, cherry. See Prunus laurocerasus

Laurel, mountain. See Kalmia latifolia

Laurel-leaf fig. See Ficus microcarpa

Lava Kumar, P., 292N, 1582N

Lavandula $\mathrm{x}$ intermedia (lavender), Fusarium sporotrichioides on, in Croatia, 591N

Lavender. See Lavandula x intermedia

Lawrence, K. S., 1805

Lawton-Rauh, A., 24, 30

Lázár, J., 1582N

Lazarotto, M., $1826 \mathrm{~N}$

Le, C. N., 389

Leach, M., 24, 30

Leandro, L. F., 1693N

Lebas, B. S. M., 463N

Lebeda, A., 1459

Lebeis, A. C., 780

LeBoldus, J. M., 833, 1071N

Lecanosticta acicola, on black pine, in Korea, $914 \mathrm{~N}$

Lecomte, P., 924

Leconte, M., 131

Ledbetter, C. A., 1037, 1488

Lee, C. K., $147 \mathrm{~N}$

Lee, H. B., $1827 \mathrm{~N}$

Lee, J., $150 \mathrm{~N}, 759 \mathrm{~N}$

Lee, J. Y., 464N, 1064N, 1222N, 1374N

Lee, K., $150 \mathrm{~N}$

Lee, S. H., $147 \mathrm{~N}, 586 \mathrm{~N}$

Lee, S. K., $1072 \mathrm{~N}$

Lee, S. Y., $1820 \mathrm{~N}$

Lee, S.-C., $759 \mathrm{~N}$

Lee, Y., $150 \mathrm{~N}$

Lee, Y. H., 142N, 1374N

Leek, Egyptian. See Allium ampeloprasum

Legler, S. E., 104

Legorburu, F.-J., 924

Legrève, A., 273

Leifert, C., 1506

Leiminger, J. H., 124

Leley, P. K., 1582N

Lens culinaris (lentil), Colletotrichum truncatum on, 1118

Lentil. See Lens culinaris

Lepidium draba, Phoma macrostoma on, 145N

Lesion nematode. See Pratylenchus agilis;

Pratylenchus vulnus

Leslie, J. F., 1111

Lettuce. See Lactuca sativa

Leveillula taurica

on Cynanchum kashgaricum, 1373N, cover photo: September

on tomato, integration of elicitors and lesssusceptible hybrids for the control of, 1506

Lewis, K., 285N

Leyva-López, N. E., 1229N

Li, B. H., $912 \mathrm{~N}$

Li, B. T., $1821 \mathrm{~N}$

Li, C., $766 \mathrm{~N}, 957$

Li, C.-P., 1072N

Li, D. W., 1069N

Li, G., $142 \mathrm{~N}$

Li, G. F., 1232N

Li, G. Q., $460 \mathrm{~N}, 588 \mathrm{~N}$

Li, H., $142 \mathrm{~N}, 804$

Li, H. L., $773 \mathrm{~N}, 1065 \mathrm{~N}$

$\mathrm{Li}, \mathrm{J} ., 142 \mathrm{~N}, 1615$

Li, P., 904N
Li, Q., 1482, 1615

Li, Q.-Q., 1143

Li, R., 296N

Li, S., 1154, 1693N

Li, S. S., $1379 \mathrm{~N}$

Li, W., 1172

Li, X., 1634

Li, X. H., 458N

Li, X. P., 914N

Li, Y., $142 \mathrm{~N}, 584 \mathrm{~N}, 1579 \mathrm{~N}, 1583 \mathrm{~N}$

Li, Y. N., $455 \mathrm{~N}$

Li, Y. P., $769 \mathrm{~N}, 1228 \mathrm{~N}, 1382 \mathrm{~N}$

Li, Z., $142 \mathrm{~N}, 1645$

Li, Z. Y., $1064 \mathrm{~N}$

Liang, C., $1695 \mathrm{~N}$

Liang, J., $1578 \mathrm{~N}$

Liao, X., $288 \mathrm{~N}$

Liarzi, O., 1513

Liberti, D., 1262

Liefting, L. W., 463N

Lilium spp., Lily mottle virus in, in Italy, 771N

Lily mottle virus (LMoV), in lily, in Italy, $771 \mathrm{~N}$

Lim, H. S., $1074 \mathrm{~N}$

Lima, N. B., 144N

Liminana, J.-M., 924

Lin, B. R., 452N, 760N, 1818N, 1819N

Lin, C.-H., $290 \mathrm{~N}$

Lin, F. Y., 1226N, 1692N, 1822N

Lin, J., 1519

Lin, W., 1143

Lin, Y. W., 593N

Liriodendron chinensis (Chinese tulip tree), 16SrV-B phytoplasma infecting, 1064N

Lisboa, D. O., $1576 \mathrm{~N}$

Litchi chinensis, Peronophythora litchii on, in Taiwan, 1224N

Little, C. R., 1775

Littlefield, L. J., 1805

Liu, A., $459 \mathrm{~N}$

Liu, D. Q., $146 \mathrm{~N}, 455 \mathrm{~N}$

Liu, F., $762 \mathrm{~N}$

Liu, G. D., 1374N

Liu, G.-J., $1704 \mathrm{~N}$

Liu, H., 354

Liu, H. L., $910 \mathrm{~N}$

Liu, H.-Y., 296N, 612, 618

Liu, J., $148 \mathrm{~N}$

Liu, J. L., 416

Liu, L. F., $146 \mathrm{~N}$

Liu, P., 1482

Liu, S., 279

Liu, T., 1615

Liu, T. G., 1601

Liu, W., $457 \mathrm{~N}$

Liu, X. L., 416, 1821N

Liu, Y., 1693N

Liu, Y. M., $1229 \mathrm{~N}$

Liu, Z., $1823 \mathrm{~N}$

Liu, Z. H., $1580 \mathrm{~N}$

Liu, Z. X., $458 \mathrm{~N}$

Liu, Z.-H., $1072 \mathrm{~N}$

Liu, Z.-X., $462 \mathrm{~N}$

Live oak. See Quercus virginiana

Livingston, S., 384

LMoV. See Lily mottle virus

Lolium perenne (perennial ryegrass), Puccinia graminis subsp. graminicola on,

Sphaerellopsis filum and, 1471

Long, D. L., 1216

Lopes, S. A., 1245

Lopez, P., 293N, 1375N

López-Herrera, C. J., 990

Lopez-Nicora, H. D., 772N, 1385N, 1556

Lorber, J. D., 648

Loropetalum chinense (Chinese fringe flower),

Phytophthora ramorum on, in California, $1829 \mathrm{~N}$

Lotus. See Nelumbo nucifera

Louws, F. J., 973 
Loyola, C., $591 \mathrm{~N}$

Lu, J. P., $288 \mathrm{~N}$

Lu, L. M., $588 \mathrm{~N}$

Lu, Q., $1578 \mathrm{~N}$

Lu, X. H., 354, 384

Lund, O. S., $760 \mathrm{~N}$

Lunden, S., $462 \mathrm{~N}$

Luo, H. D., $148 \mathrm{~N}$

Luo, J. F., 1696N

Luo, Y., 544

Luo, Z. W., $458 \mathrm{~N}$

Luongo, L., $1695 \mathrm{~N}$

Lupinus polyphyllus (garden Lupin),

Pleiochaeta setosa on, in Italy, 909N

Luque, A., $1067 \mathrm{~N}, 1375 \mathrm{~N}$

Lynch, S. C., $1070 \mathrm{~N}$

Ma, J., 1232N

Ma, Z., 1377N

Ma, Z.-H., 544

Mabagala, R. B., 760N

Mabea fistulifera, Enterobacter cowanii on, $1576 \mathrm{~N}$

MacDonald, W. L., 1608

Machado, A. C. Z., $151 \mathrm{~N}$

Machado, A. R., 1697N, 1702N

Macias, F. J., 990

MacKenzie, S. J., 522, 529

Macleaya microcarpa (smallfruit plume poppy),

Erysiphe macleayae on, in Poland, 1376N

MacMillan, T., 1271

MacRae, I. V., 497

Macroarrays, chromogenic, for plant pathogen detection, 1365

Macrophomina phaseolina on soybean

cut-stem inoculation method for evaluating resistance, 1210 effect of lactofen, azoxystrobin, and genotypes, 1148

on strawberry, in Israel, 265

Macroptilium atropurpureum (siratro),

Passiflora virus $Y$ in, $918 \mathrm{~N}$

Madden, L. V., 957, 1297

Magallanes-Tapia, M. A., $1229 \mathrm{~N}$

Magnaporthe spp.

M. oryzae

on rice, in Western Australia, 1228N on wheat, assessment of resistance among U.S. cultivars, 1501

M. poae, on annual bluegrass, in Canada, $1698 \mathrm{~N}$

Maguire, I., 1375N

Mahaffee, W. F., 726, 1343

Mahamuni, R. J., 1074N

Mahmodi, F., 1226N

Mahogany, natal. See Trichilia emetica

Mahuku, G., 1582N

Maize. See Zea mays

Maize chlorotic mottle virus (MCMV), in maize, in Kenya, $1582 \mathrm{~N}$

Majer, A., 592N

Mäkinen, V., 1430

Malabar spinach. See Basella alba

Maleita, C. M., 865

Mali, A. M., 1074N

Malihipour, A., 1016

Mallah, O. B., 149N

Malus spp.

M. $\times$ domestica (apple)

Apple mosaic virus in, $463 \mathrm{~N}$, cover photo: March

Bacillus spp. for control of pre- and postharvest diseases of, 211

Botryosphaeria dothidea on, in China, 486

Colletotrichum acutatum on: in Czech

Republic, 769N; in Italy, 144N

Colletotrichum spp. on, $458 \mathrm{~N}$, cover photo: March

Glomerella cingulata on, in China, $912 \mathrm{~N}$

Monilinia fructicola on, in Serbia, $456 \mathrm{~N}$

Penicillium carneum on, in

Pennsylvania, $1823 \mathrm{~N}$

Valsa mali var. mali on, nested PCR for

detecting in different tissues, 1645

Venturia inaequalis on: quantitative realtime PCR for assessment of growth, 1791; reduced sensitivity to QoI fungicides in Virginia and Maryland, $1376 \mathrm{~N}$

M. prunifolia (crab apple), Colletotrichum gloeosporioides on, in Korea, $766 \mathrm{~N}$

Malva parviflora (cheeseweed mallow),

Meloidogyne arenaria on, 296N

Malvaviscus arboreus, Citrus leprosis virus $C$

in, Brevipalpus phoenicis and, 968

Malvick, D. K., 1148, 1700N

Mandal, B., 468, 917N

Mandipropamid, for Phytophthora capsici, 1337

Mangifera indica (mango)

Fusarium mangiferae on in China, $762 \mathrm{~N}$ in Spain, 286N

Fusarium tupiense on, in Senegal, 1582N

Pseudofusicoccum stromaticum on, in Brazil, 144N

Xanthomonas citri pv. mangiferaeindicae on, in Mali, $581 \mathrm{~N}$

Mangla, U. N., 907N

Mango. See Mangifera indica

Mani, C., $141 \mathrm{~N}$

Manicom, B. Q., 772N

Manihot esculenta (cassava), Phytophthora

palmivora on, in China, $1072 \mathrm{~N}$

Manjunatha, S. V., 1629

Manolii, V. P., 833

Mansfield, M. A., 1692N

Mansilla Vázquez, J. P., 589N

Mao, Z. C., $904 \mathrm{~N}, 1826 \mathrm{~N}$

Marais, A., $461 \mathrm{~N}$

Marasas, W. F. O., 881

Mari, M., 144N

Marigold. See Calendula officinalis

Marine, S. C., $1376 \mathrm{~N}$

Maritime pine. See Pinus pinaster

Markell, S. G., 666, 1073N

Marois, J. J, 1581N

Marois, J. J., 1692N

Maroon-Lango, C. J., 150N

Marques, M. W., 144N

Marra, R. E., 1069N, 1070N, 1577N

Marshall, D. S., 737

Marshall, J. M., 1537

Martin, A., 1661

Martin, F. N., 1080

Martin, W. S., $759 \mathrm{~N}$

Martínez-Álvarez, P., 770N

Martín-García, J., 770N

Martini, C., 144N

Martini, P., 457N, 1823N

Maruthachalam, K., 1383N

Materazzi, A., 771N

Mathew, F. M., 666

Matoušek, J., 592N

Matsumoto, T., 917N

Mauricio-Castillo, J. A., 771N

Maurino, M. F., $1383 \mathrm{~N}$

Mauro, D., $917 \mathrm{~N}$

Mavric Pleško, I., 150N, 593N, 1582N

May, S., $147 \mathrm{~N}$

May, S. R., 1692N

Maymon, M., 286N

Mayorquin, J. S., 459N, 1070N

Mbega, E. R., 760N

McBeath, J. H., $1372 \mathrm{~N}$

McCarty, J. C., $1829 \mathrm{~N}$

McClure, M. A., 635
McCormick, S. P., 1271

McInnes, B., 1165

McKay, A., 443

McKay, A. H., 87, 235

McKemy, J. M., 146N

McLean, M. S., 569

McLeod, A., 881, 1223N, 1250, 1323

McMullen, M., 957, 1712

MCMV. See Maize chlorotic mottle virus

McTaggart, A. R., 590N, 1123

Meadow, R., 454N

Meadow hawkweed. See Hieracium

caespitosum

Medicago sativa (alfalfa)

Erwinia persicinus on, in China, $454 \mathrm{~N}$ glyphosate for foliar diseases of, 1104

Mefenoxam, Phytophthora infestans and, reappearance of sensitive populations in eastern U.S., 1315

Mehri, H. R., 1232N

Mekete, T., $1385 \mathrm{~N}, 1583 \mathrm{~N}$

Melander, C., 1638

Melanson, R. A., 1123

Melero-Vara, J. M., 990

Melgar, J., $765 \mathrm{~N}$

Meloidogyne spp. (root-knot nematodes)

M. arenaria on Anubias barteri, in China, 773N on Atractylodis macrocephalae, in China, $1583 \mathrm{~N}$ on cheeseweed mallow, $296 \mathrm{~N}$ on teak, $151 \mathrm{~N}$

M. enterolobii, on Jamaican poinsettia, in

Florida, 1706N

$M$. hispanica, biometrical, biochemical, and molecular diagnosis of Portuguese isolates, 865

$M$. incognita, on carnation, poultry manure and soil solarization for management of, 990

M. javanica, on teak, $151 \mathrm{~N}$

M. marylandi, on bermudagrass, in Florida, $1583 \mathrm{~N}$

on turfgrasses, in western United States, 635

Melon necrotic spot virus (MNSV), isolation

from weeds and cucurbits in Oklahoma, 243

Melzer, M. J., 917N, 1798

Mena-Covarrubias, J., $771 \mathrm{~N}$

Menalled, F., 1185

Mendes, R., 389

Méndez-Lozano, J., 1229N

Meng, Q., 718

Meng, Q. F., 146N

Meng, Q. X., 712, 904N

Mentha longifolia (mint), Rhizoctonia solani on, in Israel, 370

Menzel, W., 1075N

Menzies, J. G., 37

Mercado Cárdenas, G., 456N

Mersha, Z., 1382N

Mesic, A., 290N

Mesocriconema xenoplax, on peach, soil solarization and biological control for management of, 1309

Methyl gallate from Chinese sumac gallnut, inhibitory effects of on plant-pathogenic bacteria, 1193

from Toxicodendron sylvestre, for control of Ralstonia solanacearum on tomato, 1143

Mexican nut. See Jatropha curcas

Mexican petunia. See Ruellia brittoniana

Miano, D. W., 1582N

Michailides, T. J., 204, 752, 1822N

Michereff, S. J., 144N

Mikania micrantha (mile-a-minute), Puccinia

spegazzinii on, cover photo: December

Miklic Lautar, I., 773N

Miladinovic, Z., 150N 
Milbrath, L. R., 456N

Mile-a-minute. See Mikania micrantha;

Persicaria perfoliata

Miles, L. A., 1621

Miles, T. D., 1621

Milicevic, T., 290N

Milks, D. C., 1070N

Miller, G. L., 1001

Miller, P. K., 1805

Miller, S. A., 1699N

Miller, Z., 1185

Millet. See Panicum miliaceum

Milojevic, K., 918N, 1706N

Milsana, Leveillula taurica on tomato and, 1506

Milus, E., 957

Milus, E. A., 737

Mint. See Mentha longifolia

Mira, J. L., 907N

Mirabilis jalapa (four o'clock), Basella rugose mosaic virus in, in China, $294 \mathrm{~N}$

Mirabolfathy, M., 461N

Miscanthus sinenesis, Sorghum mosaic virus in, $150 \mathrm{~N}$

Mistletoe. See Psittacanthus schiedeanus

Mitkowski, N. A., 1736

Miyasaka, A., 845

MNSV. See Melon necrotic spot virus

Models. See also Warning systems

for Fusarium head blight of wheat, 889

for Fusicladium effusum on pecan, 117, 1358

for Gibberella zeae on barley, weather and, 673

for incubation period of Guignardia bidwellii on grape, 1054

sensitivity to temperature input errors associated with sampling interval and outof-canopy sensor placement, 726

VAT software for evaluation of virulence and resistance data, 1060

of yield losses in Phytophthora infestans on potato, 935

Moens, M., 774N

Moffet, M., 1185

Mohamed, M. E., 1075N

Mohammad, O., 243

Mohammadi, M. M., 1228N

Mokrini, F., 774N

Molina-Gayosso, E., 287N

Molitor, D., 1054

Mollov, D. S., 1707N

Momol, M. T., 221

Mondal, K. K., 141N

Mondal, S. N., $1225 \mathrm{~N}$

Mondino, P., 458N, 914N

Money tree. See Pachira aquatica

Monilinia spp.

M. fructicola

on apple, in Serbia, $456 \mathrm{~N}$

fungicide resistance and, 416

on plum, in Spain, $590 \mathrm{~N}$

M. polystroma, on apricot, $146 \mathrm{~N}$

Monosporascus cannonballus

on melon, in Mexico, 1068N

on watermelon, in Mexico, $1068 \mathrm{~N}$

Montelongo, M. J., 914N

Monterey cypress. See Cupressus macrocarpa

Montesinos-Herrero, C., 423

Moore, M. J., 1227N

Moorman, G. W., 147N

Mor, N., 265

Moraes, F. H. R., 1451

Moral, J., 905N

Moreno-Medina, V. R., 288N

Moretti, C., 285N

Morgan, D. P., 204

Moricca, S., 1694N, 1699N

Mortensen, C. N., 760N

Mortensen, L. M., 1653
Mostert, L., 1250

Mou, B., 618

Mountain ash. See Sorbus sp.

Mountain laurel. See Kalmia latifolia

Mpalantinaki, E., 1223N

Msallem, M., 905N

Mueller, E. E., 506

Mueller, J. D., 1805

Mugwort, Subanguina moxae on, in China, $1232 \mathrm{~N}$

Mukasa, S. B., 168

Mukhtar, I., 906N

Mulenko, W., $587 \mathrm{~N}$

Muller, E., 1445

Mullinix, B. G. Jr., 985, 1785

Mullis, S., $285 \mathrm{~N}$

Mullis, S. W., 1165

Muniz, M. F. B., 1826N

Munkvold, G. P., 1693N

Munyaneza, J. E., 18, 452N, 453N, 454N

Murphy, A., 1422

Murray, T. D., 437

Murraya paniculata, 'Candidatus Liberibacter asiaticus' on, Diaphorina citri and, 827

Muruamendiaraz, A., 924

Musa acuminata (banana), Mycosphaerella fijiensis on, 273

Mushroom, white button. See Agaricus bisporus

Muskmelon. See Cucumis melo

Muthomi, J. W., 1384N

Mycosphaerella fijiensis, on banana, 273

Mycotoxins. See also Specific toxins

Fusarium spp. on wheat, timing of fungicide application and, 845

Myers, K., 1323

Myrica rubra (Chinese bayberry, red bayberry), Pestalotiopsis spp. on

$P$. mangiferae and $P$. vismiae, in China, $588 \mathrm{~N}$

P. sydowiana, in China, $764 \mathrm{~N}$

Myung, I. S., 1222N

Myung, I.-S., 1064N

Myzus persicae, Potato virus $Y$ and, 82

Naegele, R. P., 1379N

Naidu, R. A., 1074N, 1705N

Najjar, C., $1231 \mathrm{~N}, 1703 \mathrm{~N}$

Nakajima, T., 845

Nakamura, K., 249

Nam, M., 150N

Namphueng, J., 151N

Nan, Z. B., 454N, 1374N

Nardin, I., $593 \mathrm{~N}$

Narla, R. D., 1384N

Nasehi, A., 1226N, 1227N

Nasiri, J. S., 1228N

Natal mahogany. See Trichilia emetica

Natwick, E. T., 295N

Navarro, M. J., 1067N

Navas-Castillo, J., 462N

Navrátil, M., 461N

Nazari, K., 1569

$\mathrm{Nb}$ gene, potato resistance against Potato virus $X$ and, 43

N'chimbi Msolla, S., 1230N

Ndikumana, I., $1230 \mathrm{~N}$

Neate, S. M., 673

Nectarine. See Prunus persica var. nucipersica

Nectria haematococca, on soybean, in China, $457 \mathrm{~N}$

Negrete, M. A., $1691 \mathrm{~N}$

Negussie, Z., $1230 \mathrm{~N}$

Nelson, B. D., 772N, 1829N

Nelson, M. E., 1343

Nelumbo nucifera (lotus), Curvularia lunata on, in China, $1068 \mathrm{~N}$

Nematicides, treatment of spring wheat fields with, 1537

Nemes, K., 295N
Némethy, Zs., 141N, 759N

Neocosmospora spp.

$N$. striata, on peanut, $146 \mathrm{~N}$

N. vasinfecta, on peanut, in China, $455 \mathrm{~N}$

Neofusicoccum spp.

$N$. nonquaesitum, on giant sequoia, $905 \mathrm{~N}$

N. parvum

on Acer pseudoplatanus, in Italy, 1699N

on avocado, in Mexico, $287 \mathrm{~N}$

on Quercus robur, in Italy, 1699N

Neoscytalidium dimidiatum

on Hylocereus undatus, in China, 1702N

on physic nut, in Brazil, 1697N

on pitaya, in Taiwan, $906 \mathrm{~N}$

Nepal, A., 1315

Nephelium lappaceum (rambutan)

Dolabra nepheliae on, in Honduras, $765 \mathrm{~N}$

Gliocephalotrichum spp. on, in Puerto Rico, $1225 \mathrm{~N}$

Nephelium mutabile (pulasan), Dolabra nepheliae on, in Honduras, $765 \mathrm{~N}$

Nesi, B., 771N

Nested time-release PCR, for detection of

Phomopsis sclerotioides in soil, 515

Neufeld, K. N., 345

Newman, M. A., 767N, 1805

Ngachan, S. V., $911 \mathrm{~N}$

Ngadze, E., 186

Ngugi, H. K., 211

Ni, H. F., $906 \mathrm{~N}$

Ni, H. Z., $588 \mathrm{~N}$

Ni, X. X., $1821 \mathrm{~N}$

Niblack, T. L., 772N, 1385N, 1556

Nicotiana tabacum (tobacco), Rhizoctonia solani on, $456 \mathrm{~N}, 1378 \mathrm{~N}, 1824 \mathrm{~N}$

Nie, B., 1422

Nie, X., 1422

Nigrospora oryzae on cotton, in China, 1379N

on Kentucky bluegrass, in Ontario, 909N

Nikolaeva, O. V., 1451

Nikolic, D., 149N, 918N, 1706N

Nischwitz, C., 285N, 635, 1165

Nissinen, A., 453N

Nitrogen rate, Verticillium dahliae on cotton and, 985

Nitzan, N., 370

Niu, X.-Q., 290N

Nivalenol (NIV), Fusarium spp. on wheat, timing of fungicide application and, 845

Njau, P., 1230N

Nolte, P., 453N

Nome, C., $1383 \mathrm{~N}$

Novelli, V. M., 770N

Nowakowska, M., 4

Nowicki, M., 4

Nunes, M. A., 770 N, 968

Nunez, J., 384

Nursery crops, systems approach for management of pests and pathogens of, 1236

$N x$ gene, potato resistance against Potato virus

$X$ and, 43

Nyalugwe, E. P., 43

Nyczepir, A. P., 1309

Nyerges, K., 1582N

$\mathrm{O}_{2}$, exposure to at curing temperature for control of Penicillium spp. on citrus, 423

Oak. See Quercus virginiana

Obradovic, A., 286N, 456N

O'Brien, D., 1373N

Ochwo-Ssemakula, M., 659

Ocimum basilicum (basil)

Alfalfa mosaic virus in, in California, $295 \mathrm{~N}$

Cercospora guatemalensis on, in Korea, $1580 \mathrm{~N}$

Plectosphaerella cucumerina on, in Florida, $1382 \mathrm{~N}$

Pseudomonas viridiflava on, in Hungary, 141N 
O’Connell, S., 973

Odalovic, A., 1066N

Odasso, M., 1823N

Odontoglossum ringspot virus (ORSV), in orchids, in Mexico, 464N

Odontonema cuspidatum (firespike), Cucumber mosaic virus in, in United States, 1384N

Oduro, K. A., 292N

Ohira, M., 249

Oidium spp.

O. hortensiae, on Hydrangea macrophylla, in Korea, $1072 \mathrm{~N}$

O. neolycopersici, on tomato, in Serbia, $912 \mathrm{~N}$

Oil palm. See Elaeis guineensis

Ojiambo, P. S., 345

Ok, C.-H., 552

Okabe, I., $143 \mathrm{~N}$

O'Keefe, G., $1381 \mathrm{~N}$

Olea europea (olive)

Botryosphaeria obtusa on, in Tunisia, $905 \mathrm{~N}$

Diplodia seriata on, in Croatia, 290N

Ilyonectria macrodidyma on, in California, $1378 \mathrm{~N}$

Verticillium spp. on, current status and future management prospects, 304

Olive. See Olea europea

Olive mild mosaic virus (OMMV), in spinach, in Greece, $1230 \mathrm{~N}$

Oliveira, J. R., 1576N

Oliver, C. L., $581 \mathrm{~N}$

Olivera, P. D., 623

Olsen, J., 1459

Olsen, N., 453N

Olson, S. M., 221

Omane, E., 292N

OMMV. See Olive mild mosaic virus

Ong, K. L., 1222N

Onion. See Allium cepa

Onion thrips. See Thrips tabaci

Ophel-Keller, H., 443

Ophel-Keller, K., 443

Opoku, I. Y., 292N

Orchids

Colletotrichum spp. on

C. gloeosporioides, in China, $915 \mathrm{~N}$

C. karstii, in United States, $1227 \mathrm{~N}$

Cymbidium mosaic virus and

Odontoglossum ringspot virus in, in

Mexico, 464N

Dickeya dieffenbachiae on, in China, $760 \mathrm{~N}$

Pseudocercospora odontoglossi on, 480

Oregano. See Origanum vulgare

Origanum vulgare (oregano), Golovinomyces

biocellatus on, in Italy, 457N

Ornamentals, viruses that enhance aesthetics of, 600

Ornelas, J. F., 780

Oro, V., $1583 \mathrm{~N}$

Orobanche spp. (broomrape)

O. aegyptiaca, parasitism of on sesame in Iran, $1232 \mathrm{~N}$

O. cumana, Sclerotinia sclerotiorum on, in China, $916 \mathrm{~N}$

ORSV. See Odontoglossum ringspot virus

Ortu, G., 588N, 1380N, 1825N, 1830N

Oryza sativa (rice)

Burkholderia spp. on bacteriophage for control of, 1033 detection in seed by real-time bio-PCR, 577

Curvularia fallax on, in China, 1224N

Dickeya zeae on, in China, $1818 \mathrm{~N}$

Heterodera elachista on, in China, 151N

Magnaporthe oryzae on, in Western Australia, $1228 \mathrm{~N}$

Rice yellow mottle virus in, in Burundi, $1230 \mathrm{~N}$

Sarocladium oryzae on, in Western
Australia, $1382 \mathrm{~N}$

Orzali, L., 591N

Osborne, L., 957

Osborne, L. E., 673, 1743

Ostry, M. E., $1227 \mathrm{~N}$

Ownley, B. H., 763N, 1372N

Özben, S., 762N, 766N

Pachira aquatica (money tree), Phytophthora

palmivora on, $1375 \mathrm{~N}$, cover photo: September

Pachycereus pringlei (giant cardon), Bionectria sp. on, in Mexico, 292N

Pachysandra terminalis

Cylindrocladium pseudonaviculatum on, $1069 \mathrm{~N}$

Pseudonectria pachysandricola on, in Korea, $287 \mathrm{~N}$

Volutella pachysandricola on, in China, $584 \mathrm{~N}$

Padgett, G. B., 1805

Paeonia spp. (peony)

P. suffruticosa

Fusarium solani on, in China, 909N

Fusicoccum aesculi on, $1691 \mathrm{~N}$, cover photo: November

Xanthomonas hortorum on, 581N

Paetzold, L., 943

Pale potato cyst nematode. See Globodera pallida

Palkovics, L., 141N, 148N, 295N, 759N

Palm, M. E., 1225N, 1374N

Palmateer, A. J., 293N, 480, 1375N

Palmero, D., 584N

Palou, L., 423

Pan, R., 457N, 583N, 586N

Pan, Y., 1694N

Pan, Y. M., 909N

Panax ginseng (ginseng), dodder on, 297N

Pande, S., 907N

Panicum spp.

P. liaceum (hog millet, proso millet), Rice stripe virus in, $150 \mathrm{~N}$

$P$. maximum (guinea grass),

Conidiosporomyces ayresii on, in Japan, $143 \mathrm{~N}$

P. miliaceum (hog millet, proso millet),

Acidovorax avenae subsp. avenae on, in Korea, $1222 \mathrm{~N}$

$P$. virgatum (switchgrass)

Alternaria alternata on, in Tennessee, $763 \mathrm{~N}$

Curvularia lunata var. aeria on, in United States, 1372N

Pantoea spp.

$P$. ananatis, on onion, in Korea, $1576 \mathrm{~N}$

P. stewartii, on corn, in Argentina, 1819N

Paoli, M., 771N

Papavasileiou, A., 1286

Papaver nudicaule (Iceland poppy), Fusarium oxysporum on, in Italy, $1823 \mathrm{~N}$

Papaya, Cotton leaf curl Gezira virus in, in Oman, 1704N

Papaya ringspot virus-watermelon strain

(PRSV-W), isolation from weeds and

cucurbits in Oklahoma, 243

Pappu, H. R., 468, 1384N

Par, D. S., 253

Paret, M. L., $1581 \mathrm{~N}$

Park, D. S., 577

Park, J. H., 289N, 586N, 587N, 906N, 907N,

$911 \mathrm{~N}, 914 \mathrm{~N}, 1070 \mathrm{~N}, 1072 \mathrm{~N}, 1580 \mathrm{~N}, 1701 \mathrm{~N}$, $1703 \mathrm{~N}, 1827 \mathrm{~N}$

Park, J.-H., 455N

Park, M. J., 147N, 289N, 586N, 592N, 914N, $1072 \mathrm{~N}, 1376 \mathrm{~N}, 1701 \mathrm{~N}$

Parke, J. L., 1236

Parker, S. R., 409, 1415

Parkunan, V., 1066N

Parrella, G., 294N, 462N
Pasche, J. S., 693

Paspalum vaginatum (seashore paspalum),

Laetisaria fuciformis on, in China, 1374N

Passiflora edulis (passion fruit), Potyvirus in, in Uganda, 659

Passiflora virus $Y$ (PaVY), Macroptilium

atropurpureum (siratro), $918 \mathrm{~N}$

Passion fruit. See Passiflora edulis

Pathrose, B., 144N

Patil, V. B., 1074N

Patocchi, A., 146N, 1791

Paul, C., 1210

Paul, P. A., 957

Paulitz, T. C., 584N, 591N, 1670

Pavlovic, S., 1691N

PaVY. See Passiflora virus $Y$

Pawlowski, M., 1210

Payen, C., 1375N

Paylan, I. C., $1230 \mathrm{~N}$

Payne, A. F., 117, 1358

PBCOV-HI1. See Pineapple bacilliform CO

virus-HI1

PCR (polymerase chain reaction). See also

Real-time PCR

for Burkholderia glumae on rice seed, 577

for detection and quantification of reniform nematodes, 1757

for Gaeumannomyces graminis var. tritici soil DNA concentrations, 443

nested time-release, for detection of

Phomopsis sclerotioides in soil, 515

for Puccinia striiformis f. tritici on wheat, 544

standard vs. high-fidelity, 468

for Venturia inaequalis on apple, 1791

Pea. See Pisum sativum

Peach. See Prunus persica

Peach latent mosaic viroid (PLMVd), in peach, $150 \mathrm{~N}$

Peanut. See Arachis hypogaea

Pear. See Pyrus spp.

Pecan. See Carya illinoinensis

Pecchioli, A., 1073N

Pecchioli, S., 771N

Pectobacterium spp.

$P$. carotovorum subsp. carotovorum, on potato, in China, $1819 \mathrm{~N}$

on potato, polyphenol oxidase, peroxidase, phenylalanine ammonia lyase, chlorogenic acid, and total soluble phenols and resistance, 186

P. wasabiae on potato, in Washington state, $1819 \mathrm{~N}$ on wasabi, qPCR for detection of, 253

Pedley, K. F., 1501

Peduto, F., 648, 1378N

Peek, K. S., $905 \mathrm{~N}$

Peet, M. M., 973

Pei, D., 766N

Pellé, R., 935

Peng, D. L., $151 \mathrm{~N}$

Peng, J. J., 294N

Peng, Y., 1615

Penicillium spp.

$P$. carneum, on apple (stored), in

Pennsylvania, $1823 \mathrm{~N}$

$P$. digitatum, on citrus, 423

$P$. italicum, on citrus, 423

Pensa, P., 585N, 1824N

Peony. See Paeonia spp.

Pepino. See Solanum muricatum

PepMoV. See Pepper mottle virus

Pepper. See Capsicum annuиm

Pepper mottle virus (PepMoV), in tomato, in Hawaii, 917N

Percich, J. A., 1700N

Pereira, O. L., 1697N, 1702N

Perennial ryegrass. See Lolium perenne

Peres, N. A., 522, 529, 1225N 
Perez, B. A., 764N

Perez, F. G., 587N, 1323

Pérez, M., 905N

Pérez, W. G., 1008

Pérez-Sierra, A., 1381N, 1826N

Perilla frutescens (shiso), Botrytis cinerea on,

908N, cover photo: June

Perilla-Henao, L. M., 1372N

Peronophythora litchii, on litchi, in Taiwan, $1224 \mathrm{~N}$

Peronospora variabilis, on quinoa, $146 \mathrm{~N}$

Peroxidase, resistance of potatoes to soft rot and, 186

Perrin, B., 687

Persea spp.

$P$. americana (avocado)

Fusarium sp. on, tea shot hole borer and, $1070 \mathrm{~N}$

Lasiodiplodia theobromae on, in Italy, $460 \mathrm{~N}$

Neofusicoccum parvum on, in Mexico, $287 \mathrm{~N}$

Raffaelea lauricola on, visible NIR leaf spectra as non-destructive sensing tool, 1683

P. humilis (silk bay), Raffaelea lauricola on, in Florida, 910N

Persicaria perfoliata (mile-a-minute),

Colletotrichum gloeosporioides on, in Turkey, $1578 \mathrm{~N}$

Perumal, R., 1775

Pestalotiopsis spp.

$P$. clavispora

on blueberry, in Uruguay, 914N on pecan, in Brazil, 1826N

$P$. mangiferae, on Chinese bayberry, in China, $588 \mathrm{~N}$

$P$. sydowiana, on red bayberry, in China, $764 \mathrm{~N}$

P. vismiae, on Chinese bayberry, in China, $588 \mathrm{~N}$

Peter, K. A., $1823 \mathrm{~N}$

Peters, J. C., 460N, $1701 \mathrm{~N}$

Peters, R. D., 1729

Peterson, G. L., 1501

Pethybridge, S. J., 746, 813

Petróczy, M., 148N

Pfaf-Dolovac, E., 912N

Pfaffia glomerata (Brazilian ginseng),

Cercosporella pfaffiae on, in Brazil, 1702N

Pfender, W. F., 726, 1471

Pfenning, L. H., 1581N

Phaeoacremonium scolyti, on grape, in Turkey, $766 \mathrm{~N}$

Phage fÓRSM3, for control of Ralstonia

solanacearum on tomato, 1204

Phakopsora pachyrhizi

on Florida beggarweed, in Alabama, 1374N

on soybean

pathogenic variation of isolates in U.S. in 2006-2009, 75

silicon absorption and resistance to, 37

Phalaenopsis spp.

Aphelenchoides bicaudatus on, 1763

Colletotrichum karstii on, in United States, $1227 \mathrm{~N}$

Dickeya dieffenbachiae on, in China, 760N

Pham, K. T. K., 759N

Phaseolus vulgaris (snap bean), Alfalfa mosaic virus and Cucumber mosaic virus in, crop and non-crop plants as reservoir hosts for, 506

Phenols (total soluble), resistance of potatoes to soft rot and, 186

Phenylalanine ammonia lyase, resistance of potatoes to soft rot and, 186

Philodendron, Dickeya dieffenbachiae on, in China, $452 \mathrm{~N}$

Phipps, P. M., 1805

Phoma spp.
P. costarricensis, on Delphinium

malabaricum, in India, $1074 \mathrm{~N}$

$P$. foveata, on potato, in China, $1698 \mathrm{~N}$

P. glomerata, on Schisandra chinensis, in China, $289 \mathrm{~N}$

P. herbarum, on tedera, in Australia, 769N

$P$. ligulicola var. inoxydabilis, on pyrethum, in Australia, 746

P. macdonaldii, on sunflower, in China, $1696 \mathrm{~N}$

P. macrostoma

on Conyza sumatrensis, $148 \mathrm{~N}$

on Lepidium draba, $145 \mathrm{~N}$

$P$. tropica, on lettuce, in Italy, $1380 \mathrm{~N}$

Phomopsis spp.

$P$. amygdali, on peach, in China, $288 \mathrm{~N}$

$P$. ipomoeae-batatas, on sweetpotato, in Korea, $1701 \mathrm{~N}$

P. longicolla, on soybean, in China, $1693 \mathrm{~N}$

$P$. sclerotioides, in soil, detection by nested time-release PCR, 515

on soybean, effect of lactofen, azoxystrobin and genotypes, 1148

$P$. viticola, on grape, temporal patterns of sporulation potential, 1297

Phosphate, for Phytophthora infestans on potato, 1008

Photinia serrulata, Podosphaera leucotricha on,

in China, $1695 \mathrm{~N}$

Physalis spp.

$P$. peruviana (cape gooseberry), Potato spindle tuber viroid in, $150 \mathrm{~N}$

$P$. philadelphica (tomatillo), Turnip mosaic virus in, $296 \mathrm{~N}$

Physic nut. See Jatropha curcas

Phytophthora spp.

$P$. alni, on black alder, in Spain, 589N

$P$. cambivora, on Formosan cherry, in

Taiwan, $1065 \mathrm{~N}$

P. capsici

on cucumber, evaluation for susceptibility to cucurbitaceous and solanaceous isolates, 1404 essential oils for control of, 797

sensitivity to mandipropamid, dimethomorph, and cyazofamid, 1337 on squash, cover photo: November; evaluation for susceptibility to cucurbitaceous and solanaceous isolates, 1404 on tomato, grafted, in Italy, $1830 \mathrm{~N}$ on vegetable crops in the U.S., advances in research, 1588

P. cinnamomi on mountain laurel, $1381 \mathrm{~N}$ from oak forest soils in U.S., 1608

P. colocasiae, on Colocasia esculenta (taro), in Ghana, $292 \mathrm{~N}$

P. cryptogea

on chicory, in Chile, $591 \mathrm{~N}$

on potato, in Turkey, $1224 \mathrm{~N}$ on wasabi, in Michigan, 1379N

P. dreschleri, on cabbage, in Argentina, $1830 \mathrm{~N}$

P. humicola, on Pinus pinea, in Italy, 1694N

identification and detection of, 1080, cover

photo: August

P. infestans

in eastern U.S., clonal populations and reappearance for mefenoxam sensitivity, 1315

genetic composition in Canada, migration, increased diversity and, 1729

on potato: modeling yield losses, 935 ; overview of pathology and resistance breeding, 4; phosphonate for management of in developing countries, 1008 on tomato, 4, cover photo: September

in irrigation water at nursery in Virginia,

$915 \mathrm{~N}$

lucid key to, 897

P. megasperma, on walnut, in Italy, $1695 \mathrm{~N}$

$P$. nicotianae, on potato, isolate

aggressiveness and cultivar susceptibility, 693

$P$. palmivora

on cassava, in China, 1072N

on money tree, $1375 \mathrm{~N}$, cover photo: September

$P$. ramorum

on Chinese fringe flower, in California, $1829 \mathrm{~N}$

on oak, infectivity and inoculum

production on roots, 1675

susceptibility of container weeds to, 1026

taxon Pgchlamydo, on evergreen nursery

stock in California, 1691N

Phytotoxin, Streptomyces spp. on potato and,

foliar sprays and, 97

Pianzzola, M. J., 1064N

Piao, C. G., 1583N

Piatek, M., 1376N

Picton, D. D., $1225 \mathrm{~N}$

Piercey-Normore, M., 1016

Pietilä, S., 1430

Pigeonpea. See Cajanus cajan

Pilidiella granati, on pomegranate, in Iran,

$461 \mathrm{~N}$

Pilidium concavum

on meadow hawkweed, in France, 1830N

on strawberry, in China, 1377N

Pineapple. See Ananas comosus

Pineapple bacilliform CO virus-HI1 (PBCOV-

HI1), in pineapple, diversity, detection,

distribution, and transmission, 1798

Pineapple mealybugs. See Dysmicoccus neobrevipes

Pinel-Galzi, A., 1230N

Pinho, D. B., 1697N, 1702N

Pintos Varela, C., 589N

Pinus spp. (pine)

$P$. pinaster (maritime pine), Heterobasidion annosum on, in Spain, $770 \mathrm{~N}$

$P$. pinea, Phytophthora humicola on, in Italy, $1694 \mathrm{~N}$

P. thunbergii (black pine)

Bursaphelenchus xylophilus on, 249

Lecanosticta acicola on, in Korea, 914N

Pirc, M., 141N

Pisum sativum (pea)

Boeremia exigua on, in Australia, $148 \mathrm{~N}$

Rhizoctonia solani on, isolates in North

Dakota, 666

Tomato spotted wilt virus in, in Hungary, $295 \mathrm{~N}$

Pitahaya. See Hylocereus spp.

Pitt, W. M., 1303

Pittosporum undulatum, 'Candidatus

Phytoplasma asteris' on, in Colombia, 1372N

Plasmodiophora brassicae (clubroot), in canola in Australia, $1075 \mathrm{~N}$ resistant genotypes, 833

Plasmopara obducens, on impatiens, $148 \mathrm{~N}$, $1699 \mathrm{~N}$

Platt, H. W., 1729

Platz, G. J., 569

Plazas, M. C., $1819 \mathrm{~N}$

Plectosphaerella cucumerina on basil, in Florida, 1382N

on wild rocket, in Italy, $1825 \mathrm{~N}$

Pleiochaeta setosa, on garden lupin, in Italy, $909 \mathrm{~N}$

Pleurotus eryngii (mushroom), Cladobotryum mycophilum on, in Korea, 1374N

Plewa, D. E., 459N 
Pljevljakusic, D., 1691N

PLMVd. See Peach latent mosaic viroid

Ploetz, R. C., 1683

Plum. See Prunus domestica

Plum pox virus (PPV), strain Winona, in Russia, 1135

Poa spp. (bluegrass)

P. аппиа (annual bluegrass), Magnaporthe

poae on, in Canada, $1698 \mathrm{~N}$

$P$. pratensis (Kentucky bluegrass)

Nigrospora oryzae on, in Ontario, 909N

Waitea circinata var. circinata on, in

China, $1821 \mathrm{~N}$

Podosphaera spp.

on Euphorbia spp., in Italy, 1824N

P. euphorbiaehirtae, on Jacob's ladder, in California, $1822 \mathrm{~N}$

P. leucotricha, on Photinia serrulata, in China, $1695 \mathrm{~N}$

P. macularis, on hop, spring pruning practices and, 1343

$P$. pannosa on cherry, in France, 1375N on roses, suppression by brief exposure to supplemental UV-B radiation, 1653

Poinsettia, Jamaican. See Euphorbia punicea

Pokorný, R., 769N

Poleatewich, A. M., 211

Poletto, I., $1826 \mathrm{~N}$

Poletto, T., $1826 \mathrm{~N}$

Poli, A., 291N, 909N, 910N, 1381N, 1823N, $1824 \mathrm{~N}$

Pollok, J. R., 1692N

Polyphenol oxidase, resistance of potatoes to soft rot and, 186

Pomegranate. See Punica granatum

Popko, J. T. Jr., 552

Poppy, Iceland. See Papaver nudicaule

Poppy, smallfruit plume. See Macleaya

microcarpa

Populus spp.

Apioplagiostoma populi on, in Minnesota, $1227 \mathrm{~N}$

Cytospora tritici on, in China, 1578N

P. nigra, 'Candidatus Phytoplasma asteris' on, in Colombia, $1372 \mathrm{~N}$

Porter, S. K., 459N

Postic, J., 591N

Potato. See Solanum tuberosum

Potato cyst nematode, pale. See Globodera pallida

Potato psyllid. See Bactericera cockerelli

Potato rot nematode. See Ditylenchus destructor

Potato spindle tuber viroid (PSTVd), in cape gooseberry, $150 \mathrm{~N}$

Potato virus $S$ (PVS), in potato, in Australia, strain characterization of isolates, 813

Potato virus $X$ (PVX), in potato, mixed infections with Potato virus $S$ and resistance, 43

Potato virus $Y$ (PVY)

in Kalimeris indica, in China, $1827 \mathrm{~N}$

in potato

modulation of aphid vector activity by, 82

molecular and serological analysis of strains in Brazil, 1451

response to five isolates belonging to four strains of, 1422

in Tajikistan, $1074 \mathrm{~N}$

Potyvirus spp., on sorghum, new sources of resistance in germplasm, 1775

Poultry manure, for management of

Meloidogyne incognita on carnation, 990

Pourrahim, R., 771N, 1828N

Prabha, K., 1828N

Prados, A. M., 990

Praecitrullus fistulosus (tinda), Pseudomonas aeruginosa on, $141 \mathrm{~N}$
Prasad Babu, G., 290N

Pratylenchus spp. (lesion nematode)

$P$. agilis, on wheat, in China, $773 \mathrm{~N}$

P. vulnus, on boxwood, in Ohio, $1385 \mathrm{~N}$

Pretorius, Z. A., $590 \mathrm{~N}$

Prieto-Recio, C., 770N

Prihodko, Y., 1135

Propiconazole

for Galactomyces citri-aurantii, 235

for Geotrichum candidum on peach and nectarine, 752

for Sclerotinia homoeocarpa on turfgrasses, 552

Proso millet. See Panicum miliaceum

PRSV-W. See Papaya ringspot virus-

watermelon strain

Prunus spp.

P. armeniaca (apricot), Monilia polystroma on, $146 \mathrm{~N}$

P. campanulata (Formosan cherry), Phytophthora cambivora on, in Taiwan, $1065 \mathrm{~N}$

P. cerasus (cherry)

Aspergillus niger on, in Greece, $458 \mathrm{~N}$

Calosphaeria pulchella on, in California and S. Australia, 648

Podosphaera pannosa on, in France, $1375 \mathrm{~N}$

P. domestica (plum)

Apricot pseudo-chlorotic leaf spot virus (APCLSV) in, in Czech Republic, $461 \mathrm{~N}$

Erwinia amylovora on, in Hungary, $759 \mathrm{~N}$

Hyphodermella rosae on, in Iran, $1228 \mathrm{~N}$

Monilinia fructicola on, in Spain, 590N

P. dulcis (almond)

Xylella fastidiosa on: long-term data on yield, tree vitality, and disease progress, 1037; phenology of in California nurseries, 1488

P. laurocerasus (cherry laurel), Xanthomonas arboricola on, in Netherlands, $759 \mathrm{~N}$

$P$. persica (peach)

Armillaria tabescens on, aboveground root collar excavation for management of, 681

Cylindrocarpon pauciseptatum on, in Italy, $764 \mathrm{~N}$

Geotrichum candidum on, 204, 752

Mesocriconema xenoplax on, soil solarization and biological control for management of, 1309

Peach latent mosaic viroid in, $150 \mathrm{~N}$

Phomopsis amygdali on, in China, 288N

$P$. persica var. nucipersica (nectarine)

Geotrichum candidum on, 204

propiconazole sensitivity in populations in California, 752

Pruvost, O., 193, 581N

Psathyrostachys huashanica, resistance against Puccinia striiformis f. sp. tritici on wheat and, 1482

Pseudocercospora odontoglossi, on Cattleya orchid, 480

Pseudofusicoccum stromaticum, on mango, in Brazil, 144N

Pseudomonas spp.

$P$. aeruginosa, on tinda, $141 \mathrm{~N}$

$P$. sp. BG33R, for management of

Mesocriconema xenoplax on peach, 1309

P. cannabina, on radish, in Germany, $904 \mathrm{~N}$

P. cichorii

on soybean, $142 \mathrm{~N}$

on stevia, in Florida, 1690N

on onion, $285 \mathrm{~N}$, cover photo: February

$P$. syringae pv. actinidiae, on kiwifruit, in Turkey, $452 \mathrm{~N}$
P. syringae pv. apii, on fennel, $285 \mathrm{~N}$, cover

photo: February

P. viridiflava

on artichoke, $1223 \mathrm{~N}$

on basil, in Hungary, $141 \mathrm{~N}$

on marigold, in Italy, $285 \mathrm{~N}$

Pseudonectria pachysandricola, on

Pachysandra terminalis, in Korea, 287N

Pseudoperonospora spp.

P. cubensis

on cucurbits, effects of temperature and leaf wetness on sporangia germination and infection, 345

genetic structure of populations, 1459

on hop, host specificity and, 55

P. humuli, on hop

host specificity and, 55

spring pruning practices and, 1343

Psittacanthus schiedeanus, effects of host provenance, gut passage, host fate on seedling survival, 780

PSTVd. See Potato spindle tuber viroid

Psychotria punctata (dotted wild coffee),

Cucumber mosaic virus in, in United States, $1384 \mathrm{~N}$

Psyllids. See Bactericera cockerelli; Trioza apicalis

Pteris cretica (fern), Phytophthora ramorum on, 1026

Pu, C.-J., $1698 \mathrm{~N}$

$\mathrm{Pu}, \mathrm{X}$. M., 452N, 760N, 1818N, 1819N

Puccinia spp.

P. asparagi, on asparagus, 997, cover photo:

October

P. graminis f. sp. tritici

TTKSF race, on wheat, in South Africa and Zimbabwe, 590N

on wheat, races with combined virulence to $\operatorname{Sr} 13$ and $\operatorname{Sr} 93,623$

P. graminis subsp. graminicola and, on perennial ryegrass, Sphaerellopsis filum, 1471

$P$. horiana, overwintering of in

Pennsylvania, $1381 \mathrm{~N}$

P. kuehnii, on sugarcane, in Colombia, 143N

$P$. spegazzinii, on mile-a-minute, cover

photo: December

P. striiformis f. sp. hordei, on barley, virulence, specificity and distribution of

races in U.S. in 2008-2009, 67

P. striiformis f. sp. tritici, on wheat characterization of resistance in contemporary cultivars and lines in U.S., 737

genetics of resistance in wheatPsathyrostachys huashanica translocation line h9020-1-6-8-3, 1482

race composition in Tibet, 1615

real-time PCR for detection of latent infection, 544

virulence, specificity, and distribution of races in U.S. in 2008-2009, 67

virulence dynamics and regional structure in France in 1984-2009, 131

P. triticina, on wheat new pathotype $93 \mathrm{R} 57$ in China, $1580 \mathrm{~N}$ physiologic specialization in U.S. in 2010, 1216

race and virulence dynamics in China (2000-2006), 1601

Pucciniastrum circaeae, on fuschia, in Italy, $588 \mathrm{~N}$

Pulasan. See Nephelium mutabile

Pulawska, J., 286N

Pulsatilla spp. (windflower)

Coleosporium pulsatillae on, in China, 768N

Sclerotinia nivalis on, in China, $1825 \mathrm{~N}$

Pumpkin. See Cucurbita moschata; Cucurbita pepo 
Punica granatum (pomegranate)

Alternaria alternata on, in Israel, 1513

Pilidiella granati on, in Iran, $461 \mathrm{~N}$

Puri, K. D., 1280

Purple coneflower. See Echinacea purpurea

Putnam, M. L., 583N

PVS. See Potato virus $S$

PVX. See Potato virus $X$

Pyracantha coccinea (firethorn), Erwinia

amylovora on, in Turkey, $1818 \mathrm{~N}$

Pyraclostrobin

for Botrytis cinerea on strawberry, resistance in South Carolina, 1198

for Fusarium spp. on wheat, 1495

Pyrenophora teres, on barley, 569, 1569

Pyrethrum. See Tanacetum cinerariffolium

Pyrosequencing analysis, of soil communities

suppressive to Streptomyces spp., 718

Pyrus spp. (pear)

$P$. calleryana (callery pear),

Gymnosporangium sabinae on, in New

York state, $1373 \mathrm{~N}$

P. communis (common pear)

Botryosphaeria dothidea on, in Italy, 910N

Gymnosporangium sabinae on, in New York state, $1373 \mathrm{~N}$

Pythium spp.

$P$. aphanidermatum, on cucumber, phenotypic and genotypic changes in populations over 2006-2011, 852

on carrot, fungicide sensitivity, 384

on cotton, fungicide seed treatment and, 1805

Qamar, N., 293N

Qi, A., 1291

Qin, J., 1143

Qin, W.-Q., 290N

Qiu, W., 462N

Qiu, Y., 1303

Quantitative real-time PCR, for Venturia

inaequalis on apple, 1791

Que, Y., 1519

Quensen, J. F. III, 718

Quercus spp. (oak)

Phytophthora ramorum on, infectivity and inoculum production on roots, 1675

Q. robur, Neofusicoccum parvum on, in Italy, 1699N

Q. virginiana (live oak), Diplodia corticola on, 594

Quesada-Ocampo, L., 1588

Quesada-Ocampo, L. M., 780, 1459

Quinoa. See Chenopodium quinoa

Quinone outside inhibitor (QoI) fungicides

Cercospora sojina on soybean and, $767 \mathrm{~N}$

Erysiphe necator on grape, resistance and, 1621

resazurin-based microtiter assay for sensitivity of Alternaria alternata isolates from tangerine, 1262

for Venturia inaequalis on apple, reduced sensitivity to, in Virginia and Maryland, $1376 \mathrm{~N}$

R3BV2. See Ralstonia solanacearum race 3 biovar 2

Raaijmakers, J. M., 389

Rabelo-Filho, F. A. C., 1451

Racedo, J., 765N

Radicchio. See Cichorium intybus

Radisek, S., 592N, 1065N

Radish. See Raphanus sativus

Raffaelea lauricola

on avocado, visible NIR leaf spectra as nondestructive sensing tool, 1683

on silk bay, in Florida, $910 \mathrm{~N}$

Ragazzi, A., 1694N, 1699N
Ragweed, giant. See Ambrosia trifida

Rahimian, H., 1228N

Rakhshandehroo, F., 1828N

Rakotonindraina, T., 935

Rallos, L. E., 111

Ralstonia solanacearum

Allium fistulosum extract for control of, 687 inhibitory effects of Chinese sumac gallnut extract on, 1193

race 3 biovar 2, rt-PCR assay for, 258

on tomato

filamentous phage $f$ ÓRSM3 for control of, 1204

grafting for management of, 973

Toxicodendron sylvestre leaf extract for control of, 1143

on yacon, in China, 904N

Rambutan. See Nephelium lappaceum

Ramchandra, S., 1821N

Rämert, B., 453N

Ramírez, M. M., 780

Ramirez, T., 765N

Rampersad, S. N., 1526

Ran, L. X., 146N, 455N

Ransom, J. K., 957

Rao, V. P., 1629

Rapeseed, Ethiopian. See Brassica carinata

Raphanus sativus (radish), Pseudomonas

cannabina on, in Germany, 904N

Rarisara, I., 1697N

Rascoe, J., $1225 \mathrm{~N}$

Raspberry. See Rubus spp.

Raspberry bushy dwarf virus (RBDV), in grape, in Hungary, $1582 \mathrm{~N}$

Raspberry leaf blotch virus (RLBV), in raspberry, in Finland, 1231N

Ratti, C., 296N

Rauduviniche, L., 914N

Ravanlou, A., $1222 \mathrm{~N}$

Ravi, K. S., 468

Ravi Sankar, N., 290N

Ravnikar, M., 141N

Razdan, V. K., 1067N

RBDV. See Raspberry bushy dwarf virus

Real, D., 769N, 1384N

Real-time PCR

for Burkholderia glumae on rice seed, 577

for detection and quantification of reniform nematodes, 1757

for Puccinia striiformis f. tritici on wheat, 544

for Venturia inaequalis on apple, 1791

Rebellato, J., 914N

Red bayberry. See Myrica rubra

Redinbaugh, M. G., 659, 1582N

Rehman, S., 296N

Reitz, S. R., 839

Remote sensing, for Rhizoctonia solani on sugar beet, 497

Ren, X. X., 1378N

Repetto, L., 457N, 1823N

Resazurin-based microtiter assay, for QoI sensitivity of Alternaria alternata isolates on tangerine, 1262

Reservoir hosts, for Alfalfa mosaic virus and Cucumber mosaic virus in snap bean, 506

Resistance, chemical against boscalid of Botrytis cinerea, 1197 of Didymella bryoniae, 227

of Botrytis cinerea against boscalid, 1197 against fenhexamid, $146 \mathrm{~N}$ against pyraclostrobin, 1197

of Cercospora spp.

C. beticola on sugar beet, against

terconazole, 1748

C. sojina, against QoI fungicides, $766 \mathrm{~N}$

of Didymella bryoniae against boscalid, 227

against DMI and SDHI fungicides, 978

of Erysiphe necator

against fungicides, $140 \mathrm{~N}$

against QoI fungicides, 1620

against fenhexamid, of Botrytis cinerea, $146 \mathrm{~N}$

of Monilinia fructicola, against SYP-Z048,

415

against propiconazole, of Sclerotinia

homoeocarpa on turfgrasses, 551

against pyraclostrobin, of Botrytis cinerea,

1197

of Pythium spp. on carrot, against

fungicides, 383

against QoI fungicides

of Cercospora sojina, $766 \mathrm{~N}$

of Erysiphe necator, 1620

of Venturia inaequalis on apple, $1375 \mathrm{~N}$

of Sclerotinia homoeocarpa on turfgrasses,

against propiconazole, 551

against SYP-Z048, of Monilinia fructicola, 415

against terconazole, of Cercospora beticola

on sugar beet, 1748

VAT software for evaluation of, 1059

of Venturia inaequalis on apple, against QoI fungicides, $1375 \mathrm{~N}$

Resistance, host. See Host resistance

Reveles-Torres, L. R., 771N

Reynolds, G. J., 497

Reynoutria sachalinensis (giant knotweed),

Leveillula taurica on tomato and, 1506

Rezende, J. A. M., 593N

Rhabdoviridae family virus, in maize, in

Argentina, 1383N

Rhinhart, K. E. L., 1537

Rhizoctonia spp.

$R$. solani

on cotton, fungicide seed treatment and, 1805

on Indian spinach, in Florida, 288N

on mint, in Israel, 370

on pea, isolates in North Dakota, 666

on potato, in United States, $460 \mathrm{~N}$

on Rhodiola sachalinensis, in China,

$142 \mathrm{~N}$

on sugar beet, remote sensing for

assessing severity of, 497

on tobacco, $456 \mathrm{~N}$

R. solani AG 1-IB, on malabar spinach, in

India, $911 \mathrm{~N}$

R. solani AG-1-IA, on winter savory, in Italy, $585 \mathrm{~N}$

$R$. solani AG-2-1, on canola, in Washington

state, $584 \mathrm{~N}$

R. solani $\mathrm{AG}-3$

on potato, in China, $1579 \mathrm{~N}$

on tobacco: in China, $1824 \mathrm{~N}$; in

Connecticut, $1378 \mathrm{~N}$

R. solani AG4 HG-II, on potato, in Idaho, $1701 \mathrm{~N}$

R. solani AG-A, on sugar beet, in China, $1696 \mathrm{~N}$

on sugar beet, in Iran, 398

Rhodiola sachalinensis, Rhizoctonia solani on, in China, $142 \mathrm{~N}$

Rhouma, A., $905 \mathrm{~N}$

Rhs family gene, detection of Burkholderia glumae on rice seed and, 577

Rhus chinensis (Chinese sumac), inhibitory effects of extract from on plant-pathogenic bacteria, 1193

Rial Martínez, C., 589N

Riccioni, L., 591N

Rice. See Oryza sativa

Rice stripe virus (RSV, in proso millet, $150 \mathrm{~N}$

Rice yellow mottle virus (RYMV), in rice, in Burundi, 1230N 
Richardson, K., 618

Richardson, P. A., $915 \mathrm{~N}$

Ridgwa, H. J., 144N

Rioux, S., 338

Ristaino, J. B., 1323

Ristaino, J.B., 897

Ristic, D., 149N, 918N, 1706N

Ritchie, D. F., 1638

Rivard, C. L., 973

Rivera, J., $765 \mathrm{~N}$

Rivera, V., 591N, 1291

Rivera-Varas, V., 1749

Rivera-Vargas, L. I., $1225 \mathrm{~N}$

Rizzo, D., 771N

RLBV. See Raspberry leaf blotch virus

Roberts, P. D., 1323

Robertson, N. L., 463N

Rocket, wild. See Diplotaxis tenuifolia

Rockspray. See Cotoneaster horizontalis

Rodriguez-Salamanca, L. M., 769N, 1383N

Rogers, S. A., 1638

Rojas, A., 1767

Rojas-Argudo, C., 423

Rollins, P. A., 681

Romeralo, C., $770 \mathrm{~N}$

Romero-Romero, J. L., 1229N

Rondon, S. I., 452N

Rooney-Latham, S., 291N, 905N, 1822N, $1829 \mathrm{~N}$

Root-knot nematode. See Meloidogyne arenaria

Rosa spp., Podosphaera pannosa on,

suppression by brief exposure to supplemental

UV-B radiation, 1653

Rose, L. J., 1250

Rosen, C., 1707N

Rosenzweig, N., 712, 718

Rossi, V., 104

Rosskopf, E. N., 296N

Rossman, A., $765 \mathrm{~N}$

Rothrock, C. S., 1805

Rotylenchulus reniformis (reniform nematode)

on cotton, crop rotations and, 24

genetic variability of, 30

PCR and real-time PCR for detection and quantification of, 1757

Rouse, M., 623

Rouzet, J., 131

RSV. See Rice stripe virus

Rubies Autonell, C., 296N

Rubio, I., 904N

Rubus spp.

R. crataegifolius (Korean raspberry),

Corynespora cassiicola on, in Korea, $762 \mathrm{~N}$

R. fruticosus (blackberry)

Botrytis spp. on, identification and prevalence in Carolinas, 1634

Erwinia amylovora on, in Turkey, $1818 \mathrm{~N}$

R. idaeus (raspberry), Raspberry leaf blotch virus in, in Finland, 1231N

Rudbeckia hirta var. pulcherrima (black-eyed Susan), Septoria rudbeckiae on, in Korea, $911 \mathrm{~N}$

Rueda-Puente, E. O., 292N

Ruellia brittoniana (Mexican petunia),

Sclerotium rolfsii on, in Taiwan, $1822 \mathrm{~N}$

Ruíz-Medrano, R., 464N

Runge, F., 55, 1459

Rupe, J., 1154

Rush, C. M., 943, 948

Rushanaedy, I., $917 \mathrm{~N}$

Russell, T., 763N

$R x$ gene, potato resistance against Potato virus $X$ and, 43

Ryegrass, perennial. See Lolium perenne

RYMV. See Rice yellow mottle virus

Saalau Rojas, E., 62
Sabanadzovic, S., 600

Saccharum spp. (sugarcane)

Puccinia kuehnii on, in Colombia, 143N

Sporisorium scitamineum on, molecular variation in China, 1519

Al-Sadi, A. M., 852

Šafárová, D., $461 \mathrm{~N}$

Safflower. See Carthamus tinctorius

Saftner, R. A., 1823N

Sage. See Salvia officinalis

Sahashi, N., 249

Sahin, F., 1690N, 1818N

Saidov, N., 1074N

Salamon, P., 295N

Salánki, K., 295N

Salas-Luevano, M. A., 771N

Al-Saleh, M., 1690N

Salix babylonica (weeping willow),

Colletotrichum acutatum on, in California, $1822 \mathrm{~N}$

Salvia officinalis (sage), Golovinomyces

biocellatus on, in Slovenia, 1065N

Samac, D. A., 1104

Samsatly, J., 1231N, 1703N

Samuel, S., 1286

Sanderlin, R. S., 1123

Sanders, H., $285 \mathrm{~N}$

Sanders, H. F., 1780

Sanguinaria canadensis (bloodroot), Fusarium oxysporum on, $1577 \mathrm{~N}$

Sanjuán, S., 582N

Sankaran, S., 1683

Sansevieria trifasciata, Colletotrichum sansevieriae on, in Florida, 293N

Santos-Cervantes, M. E., 1229N

Sarocladium oryzae, on rice, in Western Australia, 1382N

Saroj, A., 293N

Sarris, P. F., $1223 \mathrm{~N}$

Sato, E., 515

Satureja montana (winter savory), Rhizoctonia solani AG-1-IA on, in Italy, $585 \mathrm{~N}$

Saucedo, E. S., 1280

Saurat, C., 1069N

Savary, S., 935

Savocchia, S., 1303

Sawant, I. S., 1828N

Sawant, S. D., $1828 \mathrm{~N}$

Saxena, K. B., 907N

Sayago, P., 1819N

Sayari, M., 1228N

Sayler, R. J., 1757

SbDV. See Soybean dwarf virus

Scandiani, M., 1067N, 1375N

Schachtel, G. A., 1060

Scheets, K., 1582N

Schell, M. A., 258

Scherm, H., 705

Schilder, A. M. C., 1621

Schisandra chinensis, Phoma glomerata on, in China, 289N

Schmale, D. G. III, 279, 1376N

Schmitt, M. E., 635

Schnabel, G., 416, 681, 911N, 914N, 1198, $1634,1700 \mathrm{~N}$

Schroeder, B. K., 1548, 1819N

Schroeder, K. L., 584N, 591N

Schubert, T., 1690N

Schubert, T. S., 1225N

Schulte-Geldermann, E., 1008

Sciumbato, G. L., 1805

Sclerotinia spp.

S. homoeocarpa

on Agrostis stolonifera, in North Dakota, $1071 \mathrm{~N}$

on turfgrasses, in vitro propiconazole sensitivity and field efficacy of, 552

S. nivalis

on Chinese atractylodes, in China,
$1823 \mathrm{~N}$

on windflower, in China, $1825 \mathrm{~N}$

S. sclerotiorum

on artichoke, cover photo: January on broomrape, in China, $916 \mathrm{~N}$

effect of sclerotial water content on

carpogenic germination of, 1315

on Ethiopian rapeseed, in Florida, 1581N

on Eustoma russellianum, in Taiwan,

$910 \mathrm{~N}$

on hop, $583 \mathrm{~N}$

Sclerotium rolfsi

on groundnut, in Vietnam, 389

on Iresine herbstii, in Taiwan, 1692N

on Mexican petunia, in Taiwan, $1822 \mathrm{~N}$

on peanut, irrigation timing, fungicide

efficacy and, 1785

on swallow-worts, $456 \mathrm{~N}$

Scott, J. B., 746, 813

SDHI fungicides. See Succinate-dehydrogenaseinhibiting fungicides

Sears, J., 612

Seashore paspalum. See Paspalum vaginatum

Sechium edule (chayote), Didymella bryoniae on, in Taiwan, $1578 \mathrm{~N}$

Secor, G., 591N, 1323

Secor, G. A., 1291, 1749

Seebold, K. W. Jr., 1805

Seed treatments, for Hyaloperonospora camelinae on Camelina sativa, 1670

Seem, R. C., 1653

Seifers, D. L., 1775

Seimatosporium botan, on grape, in Chile, $1696 \mathrm{~N}$

Sekora, N. S., 1583N

Sengoda, V. G., 18, 452N, 453N, 454N

Sengooba, T., 659

Seo, S. T., 914N

Septoria spp.

S. epambrosiae, on giant ragweed, $289 \mathrm{~N}$

S. erigerontis, on giant ragweed, $1827 \mathrm{~N}$

$S$. rudbeckiae, on black-eyed Susan, in

Korea, 911N

Sequence-related amplified polymorphism (SRAP) markers, for Sporisorium scitamineum on sugarcane, 1519

Sequoiadendron giganteum (giant sequoia),

Neofusicoccum nonquaesitum on, $905 \mathrm{~N}$

Serdani, M., 583N

Serratia marcescens, on watermelon and yellow squash, in Alabama, 761N

Serrato-Diaz, L. M., 1225N

Sesamum indicum (sesame)

parasitism of broomrape on, in Iran, 1232N

Xanthomonas sp. on, $1222 \mathrm{~N}$, cover photo:

August

Sether, D. M., 1798

Setomelanomma holmii, on spruce, $459 \mathrm{~N}$

Seville root-knot nematode. See Meloidogyne hispanica

Sha, A., $1693 \mathrm{~N}$

Sha, W., 143N

Shallot virus $X$ (ShVX), in onion, in Sudan, $1075 \mathrm{~N}$

Shan, Z., 1693N

Shaner, G., 1712

Shannon, G., 1154

Sharma, B. P., 1008

Sharma, I., $1580 \mathrm{~N}$

Sharma, K., 292N, 1582N

Sharma, M., 907N

Sharma, P., 1580N

Sharma, R., 1629

Sharon, M., 370

Shen, C.-M., 1172

Shen, H. F., 452N, 760N, 1818N, 1819N

Shen, J. T., 1379N

Shen, Y. M., 910N

Sheveleva, A., 1135 
Shew, H. D. 693

Shi, F., 909N

Shi, T., 1072N

Shi, Y., 773N

Shi, Z. R., 915N, 1380N

Al-Shihi, A. A., 1704N

Shim, H. S., 577, 1222N

Shim, H.-S., 1064N

Shimoyama, N., $593 \mathrm{~N}$

Shin, H. D., 147N, 289N, 586N, 587N, 592N,

$906 \mathrm{~N}, 907 \mathrm{~N}, 911 \mathrm{~N}, 914 \mathrm{~N}, 1070 \mathrm{~N}, 1072 \mathrm{~N}$,

$1376 \mathrm{~N}, 1580 \mathrm{~N}, 1695 \mathrm{~N}, 1701 \mathrm{~N}, 1703 \mathrm{~N}$ $1827 \mathrm{~N}$

Shin, K., 910N

Shiraishi, A., 1111

Shishkoff, N., 1026, 1675

Shiso. See Perilla frutescens

Shivas, R. G., 1228N, 1382N

Shokes, F. M., 1805

Shrestha, A., 1488

Shtienberg model, for yield losses in

Phytophthora infestans on potato, 935

Shu, S. L., $906 \mathrm{~N}$

Shumway, C., 1154

ShVX. See Shallot virus $X$

Sikora, E. J., 761N, 1374N

Silicon

Mycosphaerella fijiensis on banana and, 273

soybean resistance to Phakopsora pachyrhizi and, 37

Silk bay. See Persea humilis

Silva, M., 1702N

Silva-Rojas, H. V., 287N

Silvera-Pérez, E., 914N

Simmondsia chinensis (jojoba), Elsinoë

australis on, in Australia, 629

Simões, M. J., 865

Sinatro. See Macroptilium atropurpureum

Singh, H. N., 293N

Singh, J., 141N

Singh, M., 1422

Singh, R., 761N, 1379N

Singh, R. K., $1230 \mathrm{~N}$

Singh, R. P., 623

Sir, E. B., $765 \mathrm{~N}$

Sirca, S., 773N

Sirosporium celtidis, on hackberry, in Spain, $1826 \mathrm{~N}$

Sisterson, M. S., 1037

Sitobion avenae (cereal aphid), Potato virus $Y$ and, 82

Siverio, F., 581N

16SrV-B phytoplasma, in Chinese tulip tree, $1064 \mathrm{~N}$

16SrXIIE (Stolbur group Subgroup E)

phytoplasma

in Freesia hybrida, 1820N

in potato, in China, $1372 \mathrm{~N}$

Skantar, A. M., 635

Skovorodnikova, Y., 1513

SLCV. See Squash leaf curl virus

Small, I. M., 881

Smallanthus sonchifolius (yacon), Ralstonia solanacearum on, in China, $904 \mathrm{~N}$

Smallfruit plume poppy. See Macleaya microcarpa

Small-RNA deep-sequencing (SRDS) analysis, for detection of viruses in sweet potato, 1430

Smart, C. D., 1365

Smiley, R. W., 820, 1537

Smith, D. L., 117, 1358

Smith, J. A., $910 \mathrm{~N}$

Smits, T. H. M., 146N

Snap bean. See Phaseolus vulgaris

Snover-Clift, K., 1373N

Sobh, H., 1231N, 1703N, 1704N

Sochacki, D., 594N

Soika, M. D., 1001

Soil solarization
Fusarium oxysporum f. sp. vasinfectum chlamydospore survival and, 1564

for management of Meloidogyne incognita on carnation, 990

for management of Mesocriconema xenoplax on peach, 1309

Sokhansanj, Y., 1828N

Solanum spp.

S. betaceum (tamarillo), Colletotrichum acutatum on, in United States, 587N

S. lycopersicum (tomato)

Clavibacter michiganensis subsp. michiganensis on, genetic structure of populations in Michigan, 788

Colletotrichum acutatum on, in Czech

Republic, 769N

Groundnut bud necrosis virus in, in Bangladesh, $917 \mathrm{~N}$

Leveillula taurica on, integration of elicitors and less-susceptible hybrids for the control of, 1506

Oidium neolycopersici on, in Serbia, $912 \mathrm{~N}$

Pepper mottle virus in, in Hawaii, 917N

Phytophthora spp. on: P. capsici, 1830N;

$P$. infestans, 4, cover photo: September

Ralstonia solanacearum on: filamentous phage fÓRSM3 for control of, 1204; grafting for management of, 973 ; Toxicodendron sylvestre leaf extract for control of, 1143

Stemphylium solani on, in Malaysia, $1226 \mathrm{~N}$

Tomato infectious chlorosis virus in, in Mexico, 1229N

Tomato torrado virus on, in Colombia, $592 \mathrm{~N}$

Tomato yellow ring virus in, in Kenya, $1384 \mathrm{~N}$

Xanthomonas spp. on: Acibenzolar-Smethyl (ASM) for control of, 221; in Tanzania, $760 \mathrm{~N}$

S. melongena (eggplant), Alternaria tenuissima on, in Malaysia, 1226N

S. muricatum (pepino), Tomato mosaic virus

in, in China, 1704N

S. tuberosum (potato)

Alternaria spp. on: boscalid-resistant isolates, $454 \mathrm{~N}$; early control using disease-oriented threshold values, 124

'Candidatus Liberibacter solanacearum' on: edge effect in disease intensity, 943; effects of temperature on symptom development, 18; in Idaho $453 \mathrm{~N}$; in Oregon and Washington, $452 \mathrm{~N}$; spatial patterns and spread in Texas panhandle, 948

Colletotrichum coccodes on, impact of seed lot infection on, 1179

Dickeya spp. on, polyphenol oxidase, peroxidase, phenylalanine ammonia lyase, chlorogenic acid, and total soluble phenols and resistance, 186 Fusarium spp. on, seed tubers, 1767

Globodera pallida on: in Czech Republic, 1386N; in Slovenia, 773N Impatiens necrotic spot virus, Tomato spotted wilt virus, and Tomato yellow fruit ring virus in, in Iran, $771 \mathrm{~N}$

Pectobacterium spp. on: $P$. carotovorum subsp. carotovorum, in China, $1819 \mathrm{~N}$; polyphenol oxidase, peroxidase, phenylalanine ammonia lyase, chlorogenic acid, and total soluble phenols and resistance, 186; $P$. wasabiae, in Washington state, $1819 \mathrm{~N}$ Phoma foveata on, in China, 1698N Phytophthora spp. on: P. cryptogea, in Turkey, 1224N; P. infestans, 4, 935,
1008; P. nicotianae, isolate aggressiveness and cultivar susceptibility, 693

Potato virus $S$ in, in Australia, 813

Potato virus $X$ in, mixed infections with

Potato virus $S$ and resistance, 43

Potato virus $Y$ in: modulation of aphid vector activity by, 82 ; molecular and serological analysis of strains in Brazil 1451; response to five isolates belonging to four strains of, 1422; in Tajikistan, $1074 \mathrm{~N}$

Rhizoctonia solani on: in China, $1579 \mathrm{~N}$; in Idaho, 1701N; in United States, $460 \mathrm{~N}$

Stolbur phytoplasma in, in China, 1372N

Streptomyces spp. on: S. acidiscabies, in Uruguay, 1064N; culture-based assessment of soil microbial communities suppressive to, 712 ; pyrosequencing analysis of soil microbial communities suppressive to, 718 ; in South Africa, $1223 \mathrm{~N}$, cover photo: August; S. stelliscabiei, in Michigan, 904N; thaxtomin A and, 97

Tomato chlorosis virus in, in Brazil, $593 \mathrm{~N}$

Verticillium dahliae on: impact of seed lot infection on, 1179; infected seed tubers and soilborne inoculum, 379

Solhaug, K. A., 1653

SoMV. See Sowbane mosaic virus

Sonchus asper (spiny sowthistle)

Golovinomyces cichoracearum on, in China, $766 \mathrm{~N}$

Iris yellow spot virus in, in Georgia, 1165

Song, J. G., 1373N

Song, W.-W., 290N

Sorbus sp. (mountainash), Erwinia amylovora on, in Turkey, $1818 \mathrm{~N}$

Sorghum bicolor

disease resistance in mini-core collection of, 1629

Fusarium verticillioides on, in Spain, 584N

Potyvirus spp. on, new sources of resistance in germplasm, 1775

Sorghum mosaic virus (SrMV), in Miscanthus sinenesis, $150 \mathrm{~N}$

Soriano, M. C., 1691N, 1829N

Sosnowski, M. R., 648, 1303

Soto-Valladares, A. G., 464N

Southwood, M. J., 1250

Souza, C. R. B., 144N

Souza-Dias, J. A. C., 593N

Sowbane mosaic virus (SoMV), in spinach, in

Greece, 1230N

Sowthistle, spiny. See Sonchus asper

Soybean. See Glycine max

Soybean dwarf virus (SbDV), in soybean, in

North Dakota, 1829N

Spadoni, A., 144N

Spantidakis, K., 1506

SPAP. See Sequence-related amplified polymorphism

Speckled toadlily. See Tricyrtis macropoda

SPFMV. See Sweet potato feathery mottle virus

Sphaerellopsis filum, Puccinia graminis subsp. graminicola and, 1471

Spider flower. See Tarenaya hassleriana

Spiderwort. See Commelina benghalensis

Spinach, Indian. See Basella rubra

Spinach, malabar. See Basella alba

Spinacia oleracea (spinach)

Beet necrotic yellow vein virus in, 618

Cladosporium variabile on, in California

and Arizona, $1071 \mathrm{~N}$

Olive mild mosaic virus and Sowbane

mosaic virus in, in Greece, $1230 \mathrm{~N}$

Spiny sowthistle. See Sonchus asper 
Sporisorium scitamineum, on sugarcane, molecular variation in China, 1519

Spruce, Setomelanomma holmii on, 459N

SqMV. See Squash mosaic virus

Squash, Phytophthora capsici on, cover photo: November

Squash leaf curl virus (SLCV), in cucurbits, in Lebanon, 1231N

Squash mosaic virus (SqMV), isolation from weeds and cucurbits in Oklahoma, 243

Squash vein yellowing virus (SqVYV), in watermelon, whitefly transmission and, 839

SqVYV. See Squash vein yellowing virus

SRDS. See Small-RNA deep-sequencing analysis

Srinivasan, R., 1165

Srivastava, P., 1581N, 1692N

Srivastava, S., 917N

SrMV. See Sorghum mosaic virus

Stack, J. P., 1501

Stander, M. A., 881

Stanková, B., 769N

Stankovic, I., 149N, 912N, 918N, 1698N, $1706 \mathrm{~N}$

Starovic, M., 1691N

Steciow, M., 1830N

Steel, C. C., 1303

Stefani, L., $771 \mathrm{~N}$

Stegmark, R., 453N

Stein, J. M., 673

Stemphylium spp.

S. solani

on pepper, in Malaysia, $1227 \mathrm{~N}$

on tomato, in Malaysia, $1226 \mathrm{~N}$

S. xanthosomatis, on Kalanchoe blossfeldiana, in Korea, $292 \mathrm{~N}$

Stenglein, S. A., 763N

Stensvand, A., 1653

Stevanovic, M., 912N

Stevenson, K. L., 979, 1780

Stevia rebaudiana, Pseudomonas cichorii on, in Florida, 1690N

Sthapit, J., 737

Stodart, B., 629

Stojanovic, S., 1691N

Stolbur Group Subgroup E (16SrXIIE)

Phytoplasma

in Freesia hybrida, 1820N

in potato, in China, $1372 \mathrm{~N}$

Strajnar, P., 773N

Strausbaugh, C. A., 1159

Strawberry. See Fragariae $\times$ ananassa

Strayer, A., 1690N

Strelkov, S. E., 833

Streptomyces spp.

S. acidiscabies, on potato, in Uruguay, $1064 \mathrm{~N}$

on potato

culture-based assessment of soil

microbial communities suppressive to, 712

pyrosequencing analysis of soil

microbial communities suppressive to, 718

in South Africa, fissure scab and, 1223N, cover photo: August

thaxtomin A and, foliar sprays and, 97

S. stelliscabiei, on potato, in Michigan, $904 \mathrm{~N}$

Strobilurin fungicides. See Quinone outside inhibitor) fungicides

Su, C.-C., $582 \mathrm{~N}$

Su, D., 768N, 1825N

Su, H. J., 1193

Su, Y. Y., 143N

Subanguina moxae, on mugwort, in China, $1232 \mathrm{~N}$

Subbarao, K. V., 1383N

Subbotin, S. A., 635, 1707N
Subramanian, S., 1384N

Succinate-dehydrogenase-inhibiting (SDHI) fungicides, for Didymella bryoniae on watermelon, sensitivity and resistance, 979

Sugano, J. S., 917N

Sugar beet. See Beta vulgaris

Sugar beet cyst nematode. See Heterodera schachtii

Sugarcane. See Saccharum spp.

Sugawara, K., 143N

Sulaiman, R., 767N

Sullivan, A., 1422

Sumac, Chinese. See Chinese sumac

Sumner, D. R., 1805

Sun, B. J., 1065N

Sun, H.-Y., 1172

Sun, W., 143N

Sun, W. M., 146N, 455N

Sun, X., 1690N

Sun, X. C., 1576N

Sun, X. T., 1068N

Sun, Z., 1495

Sundaraj, S., 1165

Sundheim, L., 454N

Sunflower. See Helianthus annuus

Suštaršic, M., 141N

Suthaparan, A., 1653

Sutherland, M. W., 1661

Sutton, B., 1225N, 1690N

Suwandi, 537

Suz, L. M., 1067N

Suzuki, F., 845

Swain, S. V., 1822N

Swallow-wort. See Vincetoxicum spp.

Sweet orange. See Citrus sinensis

Sweet potato. See Ipomoea batatas

Sweet potato feathery mottle virus (SPFMV), in sweet potato, effect of host plant, aphid species, and virus infection status on transmission of, 1331

Sweets, L. E., 957

Swett, C. L., $908 \mathrm{~N}$

Switchgrass. See Panicum virgatum

SYP-Z048, for Monilinia fructicola, 416

Szabo, L. J., 590N

Taheri, P., 398

Taipe, A., 1008

Tairo, F. D., 168

Taiwan cherry. See Prunus campanulata

Talavera, M., 990

Tamarillo. See Solanum betaceum

Tan, G. J., 1379N

Tan, G. Y., $588 \mathrm{~N}$

Tan, W. Z., $148 \mathrm{~N}$

Tan, Z. W., 1579N

Tanacetum cinerariifolium (pyrethrum), Phoma

ligulicola var. inoxydabilis on, in Australia, 746

Tande, C. A., 1743

Tang, Q.-H., 290N

Tang, W., 486

Tang, W. H., 1065N

Tang, X., 1501

Tangerine. See Citrus reticulata

Tao, X. R., 1229N

Tarenaya hassleriana (spider flower), Hyaloperonospora sp. on, $587 \mathrm{~N}$, cover photo: April

Tarighi, S., 398

Tarnowski, T. L. B., 293N

Taro. See Colocasia esculenta

Tatineni, S., 859

Tatsoi. See Brassica narinosa

Taylor, N. J., 1385N, 1699N

Taylor, R. J., 693

Tea shot hole borer. See Euwallacea fornicatus

Teak. See Tectona grandis

Tectona grandis (teak), Meloidogyne spp. on,
$151 \mathrm{~N}$

Tedera. See Bituminaria bituminosa

Teelucksingh, L. D., 1526

Tegg, R. S., 97

Teimoury, M., $1232 \mathrm{~N}$

Tello, J., 584N

Terconazole, for Cercospora beticola on sugar beet, 1749

Testen, A. L., 146N

Teucrium fruticans, Alfalfa mosaic virus in, in Italy, 294N

Thakur, R. P., 1629

Thanarajoo, S. S., 767N

Thaxtomin A, Streptomyces spp. on potato and, foliar sprays and, 97

Thaxton, P. M., 1805

Theobroma cacao (cocoa), Cacao swollen shoot virus in, in Côte d'Ivoire, 1445

Thines, M., 55, 1459

Thiophanate-methyl (THM), for Botrytis cinerea on strawberry, resistance in South Carolina, $1700 \mathrm{~N}$

Thomas, A., 979, 1780

Thomidis, T., $458 \mathrm{~N}$

Thrips tabaci (onion thrips), Iris yellow spot virus in onion and, $1229 \mathrm{~N}$

Tian, T., 612

Tibouchina semidecandra, Beltrania rhombica on, in China, $1380 \mathrm{~N}$

TICV. See Tomato infectious chlorosis virus

Tidwell, T. E., $905 \mathrm{~N}$

Tiedje, J. M., 718

Tilletia spp., on wheat, pathogenic races of, 361

Tinda. See Praecitrullus fistulosus

Tiodorovic, J., $1066 \mathrm{~N}$

Tipre, D. R., $141 \mathrm{~N}$

Tjamos, E. C., 304

Tjou-Tam-Sin, N. N. A., 759N

Toadlily, speckled. See Tricyrtis macropoda

Tobacco. See Nicotiana tabacum

Tobacco ringspot virus (TRSV), in cucurbits, in Oklahoma, $1705 \mathrm{~N}$

ToCV. See Tomato chlorosis virus

Toda, T., 249, 515

Tomatillo. See Physalis philadelphica

Tomato. See Solanum lycopersicum

Tomato chlorosis virus (ToCV), in potato, in Brazil, 593N

Tomato infectious chlorosis virus (TICV), in tomato, in Mexico, $1229 \mathrm{~N}$

Tomato mosaic virus (ToMV), in pepino, in China, 1704N

Tomato ringspot virus (ToRSV), in chili pepper, in Iran, $1828 \mathrm{~N}$

Tomato spotted wilt virus (TSWV) in onion and garlic, in Serbia, $918 \mathrm{~N}$ in pea, in Hungary, $295 \mathrm{~N}$ in potato, in Iran, $771 \mathrm{~N}$

Tomato torrado virus (ToTV), on tomato, in Colombia, $592 \mathrm{~N}$

Tomato yellow fruit ring virus (TYFRV), in potato, in Iran, $771 \mathrm{~N}$

Tomato yellow leaf curl virus (TYLCV), in bean, in China, $1229 \mathrm{~N}$

Tomato yellow ring virus (TYRV), in tomato, in Kenya, 1384N

Tomimura, K., 845

Tomooka, N., 562

ToMV. See Tomato mosaic virus

Tong, Y. H., 764N

Torés, J. A., $286 \mathrm{~N}$

Torrance, R., $285 \mathrm{~N}$

Torre, S., 1653

Torres, R., 768N

Torres, S. C. Z., 1245

ToRSV. See Tomato ringspot virus

Tospoviruses, as emerging problem in Indian subcontinent, 468

ToTV. See Tomato torrado virus 
Toxicodendron sylvestre, leaf extract from for control of Ralstonia solanacearum on tomato 1143

Transposable elements, in Botrytis cinerea on several hosts in Greece, 1286

Trantas, E. A., 1223N

Traoré, Y. N., $581 \mathrm{~N}$

Trapero, A., $905 \mathrm{~N}$

Tredway, L. P., 1001

Tree peony. See Paeonia suffruticosa

Tremblay, G., 338

Triazole fungicides, Galactomyces spp. and, 87

Trichilia emetica (natal mahogany), Cocconia concentrica on, $916 \mathrm{~N}$, cover photo: June

Trichothecenes, Fusarium graminearum on wheat and, 1016, 1172, 1271

Tricyrtis macropoda (specked toadlily), Colletotrichum gloeosporioides on, 1070N

Trifolium repens (white clover), Alfalfa mosaic virus in, in Oklahoma, $1705 \mathrm{~N}$

TriMV. See Triticum mosaic virus

Trioza apicalis (carrot psyllid), 'Candidatus Liberibacter solanacearum' on carrot and, $453 \mathrm{~N}$

Tripathi, S., 917N

Triticum aestivum (wheat)

Cephalosporium gramineum on, PCR-based detection, 437

Fusarium spp. on

$F$. asiaticum, pyraclostrobin and epoxiconazole for the control of, 1495

fungicide application timing and mycotoxin contamination, 845

F. graminearum: emergent Canadian chemotypes, 1271; geographic distribution of trichothecene chemotypes in China, 1172; glyphosate and different soil tillages, 338; integrating fungicide and cultivar resistance for management of, 957 molecular characterization of isolates from infected nursery in China, 1280; pyraclostrobin and epoxiconazole for the control of, 1495; united effort to fight, 1712

molecular phylogenetic analysis, trichothecene chemotype patterns, and variation in aggressiveness of isolates, 1016

F. pseudograminearum: assessing infection using quantitative PCR and visual discoloration scale, 1661; in China, $1065 \mathrm{~N}$

Gaeumannomyces graminis var. tritici on, prediction using soil DNA concentrations determined with qPCR, 443

Heterodera spp. on

H. filipjevi, in Serbia, 1583N

H. latipons, in Morocco, $774 \mathrm{~N}$

influences of nematicides and fungicides in

fields infested with soilborne pathogens, 1537

Magnaporthe oryzae pv triticum, assessment of resistance among U.S. cultivars, 150

Pratylenchus agilis on, in China, 773N

Puccinia spp. on

$P$. graminis f. sp. tritici: races with combined virulence to $\mathrm{Sr} 13$ and $\mathrm{Sr} 93$, 623; TTKSF race, in South Africa and Zimbabwe, 590N

P. striiformis f. sp. tritici: characterization of resistance in contemporary cultivars and lines in U.S., 737; race composition in Tibet, 1615; real-time PCR for detection of latent infection, 544; virulence, specificity, and distribution of races in U.S. in 2008-2009, 67; virulence dynamics and regional structure in
France in 1984-2009, 131

P. triticina: new pathotype 93R57 in China, 1580N; physiologic specialization in U.S. in 2010, 1216; race and virulence dynamics in China (2000-2006), 1601

Tilletia spp. on, pathogenic races of, 361

Triticum mosaic virus and Wheat streak mosaic virus in, 859

Xanthomonas campestris pv. translucens on evaluation of germplasm for resistance to, 1743, cover photo: December

Triticum mosaic virus (TriMV), in wheat, yield and, 859

Trivedi, B. M., 141N

Trkulja, V., $913 \mathrm{~N}$

Trouillas, F. P., 648

TRSV. See Tobacco ringspot virus

Tsai, J.-N., $1065 \mathrm{~N}, 1224 \mathrm{~N}$

Tsai, Y. C., 1578N

Tsay, T.-T., 1763

Tseng, Y.-W., 582N

Tsou, Y. R., 1193

Tsukamoto, S., 1033

Tsukiboshi, T., 143N

TSWV. See Tomato spotted wilt virus

TTKSF race, of Puccinia graminis $\mathrm{f}$. sp. tritici on wheat, $590 \mathrm{~N}$

Tu, Y. L., $1377 \mathrm{~N}$

Tugume, A. K., 168, 1430

Tulip virus $X$ (TVX), in tulip, in Poland, 594N

TuMV. See Turnip mosaic virus

Tunali, B., $1578 \mathrm{~N}$

Turechek, W. W., 1343

Turfgrasses. See also Specific species

fairy ring on, fungicides for control of, 1001

root-knot nematodes on, in western United

States, 635

Sclerotinia homoeocarpa on, in vitro propiconazole sensitivity and field efficacy of, 552

Turkington, T. K., 569, 833

Turnip mosaic virus (TuMV), in tomatillo, $296 \mathrm{~N}$

TVX. See Tulip virus $X$

Twizeyimana, M., 75, 1070N, 1210

Twomey, M. C., 583N

TYFRV. See Tomato yellow fruit ring virus

TYLCV. See Tomato yellow leaf curl virus

Type III effector proteins, genetic diversity of Brazilian strains of Xanthomonas citri subsp. citri and, 193

TYRV. See Tomato yellow ring virus

Tzanetakis, I. E., 1230N

Uccello, A., 1694N, 1699N

Uchida, J. Y., 1111

Ugandan Passiflora virus, in passion fruit, in Uganda, 659

Upadhyaya, H. D., 1629

Urban, J., 1386N

Úrbez-Torres, J. R., 1378N

Urek, G., 773N

Uromyces spp.

U. plumbarius, on Gaura lindheimeri, in Louisiana, $590 \mathrm{~N}$

$U$. striatus, on alfalfa, glyphosate for control of, 1104

Urrea, C. A., 1073N

UV-B treatment, Podosphaera pannosa on roses and, 1653

Uzunok, S., 762N, 766N

Vaccinium corymbosum (blueberry) Blueberry red ringspot virus in, in Korea, $1074 \mathrm{~N}$

Botryosphaeria dothidae on, in China, $1697 \mathrm{~N}$

Diaporthe australafricana on, in Chile,
$768 \mathrm{~N}$

Glomerella cingulata on, in Argentina, $764 \mathrm{~N}$

Pestalotiopsis clavispora on, in Uruguay, $914 \mathrm{~N}$

Vadamalai, G., 767N

Vail, S., 1118

Valent, B., 1501

Valkonen, J. P. T., 168, 1231N, 1430

Vallad, G. E., 221

Valsa mali var. mali, on apple, nested PCR for detecting in different tissues, 1645

Valverde, R. A., 600

Van de Bilt, J. L. J., 759N

Van der Linde, E. J., 916N

Van der Waals, J. E., 186

Van Doorn, J., 759N

Van Sanford, D., 1712

Van Vuuren, S. P., 772N

Van Wyk, S. J. P., 875

Vanasse, A., 338

Vandenberg, A., 1118

Vandepitte, J., 889

Vargas, J. M. Jr., 1736

Vargas, M., 591N

Varrelmann, M., 1045

Varvaro, L., $1577 \mathrm{~N}$

Vasic, M., 456N

Vasic, T., 913N

Vásquez-Siller, L. M., 437

VAT. See Virulence Analysis Tool

Vaz, A. B., 1581N

VCG tests. See Vegetative compatibility group tests

Veerakone, S., 463N

Vega, B., 1262

Vega, W. L. Orduño, 1229N

Vegetative compatibility group (VCG) tests, on Fusarium spp. on koa, 1111

Végh, A., 141N, 759N

Vela, M. D., 990

Velasquez-Valle, R., 771N

Velez, M. L., 1830N

Veloukas, T., 1286

Ventura, J. A., $1581 \mathrm{~N}$

Venturia inaequalis, on apple quantitative real-time PCR for assessment of growth, 1791

reduced sensitivity to QoI fungicides in

Virginia and Maryland, $1376 \mathrm{~N}$

Verbeek, M., 592N

Verbena sp., Citrus exocortis viroid in, in

Montenegro, 593N

Verdier, E., 1064N

Verhalen, L. M., 1805

Verniere, C., $581 \mathrm{~N}$

Vernière, C., 193

Verticillium spp.

V. dahliae

on cotton, effects of crop rotation, cultivar, irrigation and nitrogen rate on, 985

on potato: impact of seed lot infection on, 1179; infected seed tubers and soilborne inoculum, 379

on spineless safflower, in California, $1383 \mathrm{~N}$

on olive, current status and future

management prospects, 304

Ververidis, F. N., 1223N

Vetch, hairy. See Vicia villosa

Vetten, H. J., 1045

Viaene, N., 774N

Vicent, A., 907N

Víchová, J., 769N

Vicia spp.

$V$. faba (faba bean), nonoviruses on in

Ethiopia, 1045

$V$. villosa (hairy vetch), cover crop for 
disease control in watermelon, 43

Vico, I., 1823N

Victoria, J. I., 143N

Vigna angularis var. angularis (adzuki bean) Cadophora gregata f. sp. adzukicola on, 562

Fusarium oxysporum f. sp. adzukicola on, 562

Viljoen, A., 875, 881, 1250

Villaescusa, F. J., 581N, 582N

Villinger, J., 1384N

Vinatzer, B. A., $581 \mathrm{~N}$

Vincent, S. J., 1384N

Vincetoxicum spp. (swallow-wort) as alternate host of Cronartium flaccidum, $585 \mathrm{~N}$ Sclerotium rolfsii on, $456 \mathrm{~N}$

Viotti, G., 1375N

Viršcek Marn, M., 150N, 593N, 1582N

Virulence, VAT software for evaluation of, 1060

Virulence Analysis Tool (VAT), overview of, 1060

Visible-near infrared reflectance spectra, for detecting Raffaelea lauricola on avocado, 1683

Visser, B., 590N

Vital, K., 581N

Vitale, S., $1695 \mathrm{~N}$

Vitis vinifera (grape)

Agrobacterium vitis on, in Serbia, $286 \mathrm{~N}$

Botryosphaeriaceae on, evaluation of

fungicides for management of, 1303

Cylindrocarpon macrodidymum on, in

Turkey, $762 \mathrm{~N}$

Cylindrocladiella spp. on

C. parva: in New Zealand, $144 \mathrm{~N}$; in Spain, 1381N

C. peruviana, in Spain, $1381 \mathrm{~N}$

Erysiphe necator on, cover photo: May

in Peru, $768 \mathrm{~N}$

QoI fungicide-resistant in Michigan, 1621

sensitivity to demethylation inhibitor

fungicides, 111

warning system for early-season control of, 104

esca on, 924, cover photo: July

Eutypa lata on, in Serbia, 913N

Grapevine fleck virus in, in Idaho, 1705N

Grapevine leafroll-associated virus 1 in, in India, $1828 \mathrm{~N}$

Grapevine leafroll-associated virus 2 in, in Missouri, 462N

Grapevine Leafroll-associated virus 4 in, in Turkey, 1230N

Guignardia bidwellii on, cumulative degree day-based model to calculate the duration of the incubation period of, 1054

Phaeoacremonium scolyti on, in Turkey, $766 \mathrm{~N}$

Phomopsis viticola on, temporal patterns of sporulation potential, 1297

Raspberry bushy dwarf virus in, in Hungary, $1582 \mathrm{~N}$

Seimatosporium botan on, in Chile, 1696N

Voloudakis, A. E., 1230N

Volutella pachysandricola, on pachysandra, in China, 584N

Vossbrinck, C. R., 1378N

Vrandecic, K., 591N, 1698N

Vu, A. L., 763N, 1372N

Vucurovic, A., 149N, 912N, 918N, 1698N, $1706 \mathrm{~N}$

Waegeman, W., 889

Waeyenberge, L., 774N, 1583N

Waitea circinata var. circinata

on creeping bentgrass, in China, $1821 \mathrm{~N}$

on Kentucky bluegrass, in China, 1821N
Walcott, R. R., 705

Waldrop, V., 1309

Walker, A.-S., $147 \mathrm{~N}$

Walker, C., 1757

Walker, D., $765 \mathrm{~N}$

Walls, J. T., 1066N

Walnut. See Juglans regia

Walter, A. J., 827

Wan, A. M., 67

Wang, B., 1482, 1615

Wang, C. P., 769N, 1228N, 1382N

Wang, C. S., $1579 \mathrm{~N}$

Wang, C. X., 912N

Wang, D., $1385 \mathrm{~N}$

Wang, D. H., 1070N

Wang, F., 914N, 1634, 1827N

Wang, F. C., $910 \mathrm{~N}$

Wang, G., 1373N

Wang, G. L., 1579N

Wang, H. Y., 912N

Wang, H.-Q., 1704N

Wang, J., 289N

Wang, J. G., 294N

Wang, J.-H., 462N

Wang, L. F., 1583N, 1821N

Wang, N.-Y., $1225 \mathrm{~N}$

Wang, P. P., 1696N

Wang, S.-W., 1072N

Wang, W.-X., 1495

Wang, X., 142N, 289N, 804, 1645

Wang, X. H., 458N

Wang, X. Z., 1583N

Wang, Y., 588N, 913N, 917N, 1615

Wang, Y. G., 588N

Wang, Y. Y., 1694N

Wang, Y. Z., 486

Wang, Z. R., 764N

Wang, Z. Y., 773N, 904N, 917N

Wangai, A. W., 1582N

Ward, L., 463N

Warning systems. See also Models for Erysiphe necator on grape, 104

Wasabia japonica (wasabi)

Pectobacterium wasabiae on, qPCR for detection of, 253

Phytophthora cryptogea on, in Michigan, $1379 \mathrm{~N}$

Watanabe, S., 917N

Watermelon. See Citrullus lanatus

Watermelon bud necrosis virus, on watermelon, cover photo: April

Watermelon chlorotic stunt virus (WmCSV) in cucurbits, in Lebanon, $1703 \mathrm{~N}$ in watermelon, $149 \mathrm{~N}$

Watermelon mosaic virus-1 (WMV-1), isolation from weeds and cucurbits in Oklahoma, 243

Watermelon mosaic virus-2 (WMV-2), isolation from weeds and cucurbits in Oklahoma, 243

Watson, A. K., $285 \mathrm{~N}$

Wax gourd. See Benincasa hispida

Waxman, K. D., 957

Wayadande, A. C., 761N

Weather conditions

Botrytis cinerea on strawberry, timing of fungicide applications, 529

Colletotrichum acutatum on strawberry, timing of fungicide applications, 522

Pseudoperonospora cubensis on cucurbits and, 345

Webb, S. E., 839

Webster, C. G., 1384N

Wechter, W. P., 1309

Weeping willow. See Salix babylonica

Wegulo, S. N., 859, 957

Wehrhahne, L., 763N

Wei, M. S., 1232N

Wei, Y. M., 1377N

Welker, R. M., 973

Wen, A., 221
Wen, C. Y., $913 \mathrm{~N}$

Wenninger, E. J., 1159

Westerhof, J., 759N

Wetzel, H. C. III, 437

Wharton, P., 454N

Wharton, P. S., 460N, 1701N

Wheat. See Triticum aestivum

Wheat curl mites. See Aceria tosichella

Wheat streak mosaic virus (WSMV) alternate hosts in Great Plains, 1185 in wheat, yield and, 859

Wheeler, T. A., 985, 1805

White button mushroom (Agaricus bisporus). See Agaricus bisporus

White clover. See Trifolium repens

Whitefly. See Bemisia tabaci

Wicker, E., 687

Widmer, T. L., 1675

Wild rocket. See Diplotaxis tenuifolia

Williamson, M., 911N

Willow, weeping. See Salix babylonica

Willowherb, northern. See Epilobium ciliatum

Willyerd, K. T., 957

Wilson, C. R., 43, 97

Windels, C. E., 497

Windflower. See Pulsatilla koreana; Pulsatilla spp.

Winter, S., 659, 1075N

Winter savory. See Satureja montana

Wintermantel, W. M., 295N

Winters, S. A., 1805

Wise, K., 957

Witches'-broom disease, on purple coneflower, in Taiwan, $582 \mathrm{~N}$

Withania somnifera (Ashwagandha),

Choanephora cucurbitarum on, in India, 293N

WmCSV. See Watermelon chlorotic stunt virus

WMV. See Watermelon mosaic viruses

Wolcan, S., 592N

Wong, M. Y., 1226N, 1227N

Wong, M.-Y., 1365

Wood, E., 454N

Woodhall, J. W., 460N, 1701N

Woods, J. L., 583N, 1343

Woodward, J. E., 985, 1785

Workneh, F., 943, 948

Worthington, R. J., 1638

Wosula, E. N., 1331

Wrather, A., 1154

Wright, D. G., 769N

Wright, D. L., $1581 \mathrm{~N}, 1692 \mathrm{~N}$

Wright, D. W., 1075N

Wright, E. R., 764N

WSMV. See Wheat streak mosaic virus

Wu, H. Y., 913N, 917N, 1691N

Wu, J. M., 1064N, 1222N

Wu, M. Y., 593N

Wu, P. S., $1696 \mathrm{~N}$

Wu, X., 1579N, 1697N

Wu, X. H., 1696N

Wu, X. X., 904N

Wu, Y. H., $1827 \mathrm{~N}$

Wu, Y. X., 904N, 1826N

Wu, Y.-H., 1824N

Wu, Y.-P., 462N

Wulff, E. G., 760N

Xanthomonas spp.

$X$. arboricola on cherry laurel, in Netherlands, 759N on hazelnut, $1577 \mathrm{~N}$

$X$. campestris, on Zinnia elegans, in Korea, $1064 \mathrm{~N}$

$X$. campestris pv. translucens, on wheat, evaluation of germplasm for resistance to, 1743, cover photo: December

$X$. campestris pv. vesicatoria, on pepper, in Saudi Arabia, 1690N

$X$. citri, on mango, in Mali, $581 \mathrm{~N}$ 
X. citri pv. citri

genetic diversity of Brazilian strain collection based on type III effector protein genes, 193

inhibitory effects of Chinese sumac gallnut extract on, 1193

X. cucurbitae

inhibitory effects of Chinese sumac gallnut extract on, 1193 on pumpkin, in Illinois, $1222 \mathrm{~N}$

$X$. euvesicatoria inhibitory effects of Chinese sumac gallnut extract on, 1193 on pepper, foliar-applied small molecule that suppresses biofilm formation and enhances control of copper-resistant, 1638

$X$. hortorum

on ivy, $141 \mathrm{~N}$, cover photo: January on peony, $581 \mathrm{~N}$ on radicchio, $1820 \mathrm{~N}$

on sesame, $1222 \mathrm{~N}$, cover photo: August on tomato, in Tanzania, $760 \mathrm{~N}$

Xi, P.-G., 1702N

Xia, H., 1224N

Xiang, M. M., 915N, 1380N

Xiang, Z., 586N

Xiao, F., 1377N

Xie, C., 1422

Xie, H., 773N

Xie, S. N., 917N

Xie, Y., 142N, 584N

Xie, Y. Y., 1579N

Xing, H. H., $1695 \mathrm{~N}$

Xing, X. P., 1065N

Xing, Y. P., 764N

Xiong, R. Y., 1229N

Xiong, Z., 462N

Xoconostle-Cazares, B., 464N

$\mathrm{Xu}, \mathrm{B} ., 1373 \mathrm{~N}$

Xu, B. C., $1825 \mathrm{~N}$

$\mathrm{Xu}$, C. L., $773 \mathrm{~N}$

Xu, D., $296 \mathrm{~N}, 457 \mathrm{~N}, 583 \mathrm{~N}$

$\mathrm{Xu}, \mathrm{F} ., 460 \mathrm{~N}$

Xu, H. J., $1823 \mathrm{~N}$

$\mathrm{Xu}$, J. Y., 764N

Xu, L., 1519

Xu, S. G., 1697N, 1821N

$\mathrm{Xu}, \mathrm{X} ., 766 \mathrm{~N}, 1615$

Xue, J. P., 1232N

Xylella fastidiosa

on almond

long-term data on yield, tree vitality, and disease progress, 1037

phenology of in California nurseries, 1488

on citrus, responses to infection, 1245

on pecan, 1123

Yacon. See Smallanthus sonchifolius

Yaghmour, M. A., 204, 752

Yago, J., 150N

Yahyaoui, A., 623

Yakabe, L. E., 409, 1415, 1691N

Yamada, T., 1204

Yan, J.-H., 544

Yan, X. R., 768N

Yang, C., 1693N

Yang, C.-D., 1698N
Yang, F. Y., 1823N

Yang, H., 1072N

Yang, H. R., 906N

Yang, H.-C., 1699N

Yang, H.-R., 1224N

Yang, L., 289N, 460N

Yang, L. N., 297N

Yang, M., 1615

Yang, S.-J., $762 \mathrm{~N}$

Yang, X., 915N

Yang, Y., 1579N

Yang, Z., 1693N

Yang, Z. H., 146N

Yang, Z. L., 588N

Yao, R. Y., 1232N

Yao, Z. Q., $916 \mathrm{~N}$

Yaseen, T., 764N

Ye, Y.-F., 1143

Yellow squash, Serratia marcescens on, in Alabama, $761 \mathrm{~N}$

Yin, J., 294N, 1337

Yin, J. F., 712

Yin, Z., 1645

Yoder, K. S., 1376N

Yoo, H. L., 1064N, 1222N

Yoon, Y., 150N

Yoshida, M., 845

You, M. P., 769N, 1228N, 1382N

Young, B. G., 957

Young, H. M., 1581N, 1692N

YrH9020 gene, genetics of resistance in wheatPsathyrostachys huashanica translocation line h9020-1-6-8-3, 1482

Yu, F.-Y., 290N

Yu, L., 460N, 1697N, 1821N

Yu, N. T., $458 \mathrm{~N}$

Yu, N.-T., 462N

Yu, Q., 297N

Yu, S. Q., 1691N

Yu, S.-M., 142N

Yu, T.-A., $918 \mathrm{~N}$

Yu, W. G., 1229N

Yuan, G.-Q., 1143

Yuan, H. X., 1065N

Yuan, Z. L., 588N

Yuvaraj, J. K., 453N

Zacaroni, A. B., $1820 \mathrm{~N}$

Zaida, M. A., 297N

Zainal Abidin, M. A., $1226 \mathrm{~N}, 1227 \mathrm{~N}$

Zale, J., 763N, 1372N

Zang, R., 1645

Zapata, N., 591N

Zea mays (corn, maize)

Fusarium verticillioides on, resistance in inbred lines, fumonisin accumulation and, 881

Pantoea stewartii on, in Argentina, 1819N

Rhabdoviridae family virus in, in Argentina, $1383 \mathrm{~N}$

Zebra chip (ZC) disease. See also 'Candidatus

Liberibacter solanacearum'

Zeng, R., 288N

Zhan, R.-L., 762N

Zhang, A.-F., 1495

Zhang, C. Q., $1825 \mathrm{~N}$

Zhang, G. R., 767N

Zhang, G. Z., 1378N

Zhang, J., 460N, 804, 916N
Zhang, J. F., 773N

Zhang, J. X., 1819N

Zhang, J. Z., 1377N

Zhang, L., 1372N

Zhang, L. L., 1373N

Zhang, L. X., 1379N

Zhang, M., 773N, 913N, 917N, 1691N

Zhang, Q., 1071N

Zhang, Q. T., 1578N

Zhang, S., 221, 288N, 588N, 1072N, 1382N

Zhang, S.-Y., $462 \mathrm{~N}$

Zhang, T. X., 764N

Zhang, W., 1374N

Zhang, X. K., 916N

Zhang, X. L., $1696 \mathrm{~N}$

Zhang, X. Y., 1578N

Zhang, Y., 1495

Zhang, Y. L., $586 \mathrm{~N}$

Zhang, Y. X., 915N, 1380N

Zhang, Y.-L., $462 \mathrm{~N}$

Zhang, Z., 1372N

Zhang, Z. F., 454N, 912N

Zhao, C. B., 773N

Zhao, J. R., 1697N, 1821N

Zhao, S. F., $916 \mathrm{~N}$

Zhao, T. M., 1229N

Zhao, W. J., 1576N

Zhao, X. Y., 1377N

Zhao, X.-X., 1824N

Zhao, Y.Z., 1580N

Zhao, Y.-L., 762N

Zhao, Y.-Q., 1824N

Zhao, Z. Y., 1373N

Zhen, F., 1438

Zheng, J. F., 1821N

Zheng, J. T., 764N

Zheng, L., 909N

Zhong, S., 1111, 1280

Zhou, B. G., $1827 \mathrm{~N}$

Zhou, J. N., 452N, 760N, 1818N

Zhou, M.-G., 1495

Zhou, R. J., 768N, 1823N, 1825N

Zhou, T., 416

Zhou, X. G., 431

Zhou, X. W., 1229N

Zhou, X-A., 1693N

Zhou, Y. J., 1229N

Zhou, Z. Q., 486

Zhu, H., 290N

Zhu, L., 804

Zhu, S. F., 1232N

Zhu, X. F., 1694N

Zindovic, J., 150N, 593N

Zinnia elegans, Xanthomonas campestris pv. zinniae on, in Korea, 1064N

Živkovic, S., 913N, 1583N

Zizyphus jujuba (jujube), Fusarium spp. on F. oxysporum, in China, $586 \mathrm{~N}$ F. proliferatum, in China, $913 \mathrm{~N}$

Zoghlami, N., 1569

Zou, Y., 1072N

Zouhar, M., 1386N

Zucchini yellow mosaic virus (ZYMV) isolation from weeds and cucurbits in Oklahoma, 243

in watermelon, in Serbia, $149 \mathrm{~N}$

Zveibil, A., 265

ZYMV. See Zucchini yellow mosaic virus 